\title{
A Portrait of the Library: A Fine History
}

by

Victoria Catherine Passau

Submitted to the School of Information Management,

Victoria University of Wellington

in partial fulfilment of the requirements for the degree of Master of Library and Information Studies 


\section{Acknowledgements}

I would like to thank the following individuals and organisations who have contributed to the completion of this research. My supervisor, Dr Sydney Shep for her guidance and advice throughout this project; LIANZA and the Paul Szentirmay Scholarship for their generous award; the oral history participants who kindly agreed to be interviewed and share their experiences; those who provided written responses; those individuals and organisations who allowed me to reproduce their images; all The University of Auckland staff and departments who allowed me access to records and resources, in particular the staff at the General Library Special Collections; the encouragement, assistance and understanding of my manager Jane Wild and that of the whole Fine Arts Library team has been greatly appreciated; and finally my parents and family whose constant support and encouragement has sustained me throughout this time. 


\section{Contents}

Introduction $\quad 1$

$\begin{array}{ll}\text { Purpose Statement } & 2\end{array}$

Research Questions

$\begin{array}{ll}\text { Delimitations / Limitations } & 4\end{array}$

$\begin{array}{ll}\text { Disclaimer } & 4\end{array}$

$\begin{array}{ll}\text { Literature Review } & 5\end{array}$

$\begin{array}{ll}\text { Paradigm } & 9\end{array}$

$\begin{array}{ll}\text { Theoretical Framework } & 10\end{array}$

Methodology and Data Collection 11

$\begin{array}{ll}\text { Data Analysis } & 15\end{array}$

$\begin{array}{ll}\text { Limitations of Methodology } & 17\end{array}$

$\begin{array}{ll}\text { Chapter One: 1950-1961 } & 18\end{array}$

$\begin{array}{ll}\text { Chapter Two: 1962-1976 } & 29\end{array}$

Chapter Three: 1976-1990 $\quad 57$

Chapter Four: 1990-1999 66

$\begin{array}{ll}\text { Chapter Five: 1999-2007 } & 77\end{array}$

Chapter Six: 2007-Present

$\begin{array}{ll}\text { Chapter Seven: Future } & 90\end{array}$

$\begin{array}{ll}\text { Conclusion } & 94\end{array}$

Opportunities for Further Research 96

$\begin{array}{ll}\text { Bibliography } & 97\end{array}$

$\begin{array}{ll}\text { Appendix 1: List of Figures } & 129\end{array}$ 


\section{List of Figures}

\section{For full citations see Appendix 1}

$\begin{array}{lll}\text { Figure } 1 & \text { Elam School of Fine Arts, Newton West site (1963) } & 19\end{array}$

Figure $2 \quad$ Proposed layout of library at Newton West in (1951) 21

Figure 3 View of the library at the Elam School of Fine Arts, Newton West (1958)

Figure 4 View of the library at the Elam School of Fine Arts, Newton West (1962)

Figure 5 Elevation of School of Fine Arts at Whitaker Place (1960). Highlighted area showing library in relation to the rest of the Fine Arts buildings

Figure $6 \quad$ Administration wing and Library at Whitaker Place (1968)

Figure 7 Plans of the Elam School of Fine Arts at Whitaker Place (1960)

Figure 8 Original layout of the Fine Arts Library at Whitaker Place (1960)

Figure 9 Plan of Library with suggestions for permanent workroom by Richards (1965)

$\begin{array}{lll}\text { Figure } 10 & \text { Fine Arts Library (1968) } & 36\end{array}$

$\begin{array}{lll}\text { Figure } 11 & \text { Richards in the Fine Arts Library (1969) }\end{array}$

Figure 12 Richards and students in the Fine Arts Library (1969). 37

Figure 13 Richards in the mezzanine reading area facing southern wall (1969) 38

Figure 141965 drawing by Richards for the proposed extensions to the Fine Arts Library (Mezzanine Floor, Periodicals Only)

Figure 151965 drawing by Richards for the proposed extensions to the Fine Arts Library (Ground Floor)

Figure 16 Fine Arts Library front desk in 1975

Figure 17 Richards looking through ephemera files while unidentified student looks at press cuttings display (1969)

Figure 18 Richards receiving cheque from Fletcher Industries for fence painting 
competition, c.1968

Figure 191972 cover of Fine Arts Library Bulletin (v.23) by Richard Wolfe. 46

$\begin{array}{lll}\text { Figure } 20 & \text { Open Drawers (1975) }\end{array}$

Figure 21 Additions to School of Fine Arts - Main \& Mezzanine Floor Plan (1975) 55

Figure 22 Exterior photograph of the Fine Arts Library extension (1976) 57

Figure 23 Fine Arts Library staff moving books and periodicals (1976) 57

Figure 24 Photograph of Elam and Library staff (1976) 58

Figure 25 Interior photograph of the Fine Arts Library from front (1976) 59

Figure 26 Interior photograph of the Fine Arts Library from rear (1976) 59

Figure 27 Entrance and front desk of the Fine Arts Library (c.1977) 60

$\begin{array}{lll}\text { Figure } 28 & \text { Professor Paul Beadle's farewell (1982) }\end{array}$

$\begin{array}{lll}\text { Figure } 29 & \text { Valerie Richards on her retirement (1990) }\end{array}$

$\begin{array}{lll}\text { Figure } 30 & \text { Gail Keefe at the front desk (1990) }\end{array}$

$\begin{array}{lll}\text { Figure } 31 \quad \text { Card catalogue and front desk arrangement (c.1990-1994) } & 69\end{array}$

$\begin{array}{lll}\text { Figure } 32 & \text { Library assistant desks (c.1990-1994) }\end{array}$

$\begin{array}{lll}\text { Figure } 33 & \text { Typewriter in backroom (c.1990-1994) }\end{array}$

$\begin{array}{lll}\text { Figure } 34 & \text { Fine Arts Library staff (c.1990-1994) } & 71\end{array}$

$\begin{array}{lll}\text { Figure } 35 & \text { Fine Arts Library staff (c.2001) } & 78\end{array}$

$\begin{array}{lll}\text { Figure } 36 & \text { Proposal layout for front desk (c.2001) } & 79\end{array}$

$\begin{array}{lll}\text { Figure } 37 & \text { Front desk of the Fine Arts Library (2011) } & 79\end{array}$

$\begin{array}{lll}\text { Figure } 38 & \text { Fine Arts Library Staff (2011) }\end{array}$

$\begin{array}{lll}\text { Figure } 39 & \text { New books and serial reading area (2011) }\end{array}$

$\begin{array}{lll}\text { Figure } 40 & \text { Fine Arts Library book stacks (c.1990-1994) } & 88\end{array}$

$\begin{array}{lll}\text { Figure } 41 & \text { Fine Arts Library book stacks (2011) } & 88\end{array}$ 


\section{List of Abbreviations}

Art History: Department of Art History, The University of Auckland

AU: The University of Auckland General Library

AUEL: Fine Arts Library, The University of Auckland

AULS: The University of Auckland Library System

Elam: Elam School of Fine Arts, The University of Auckland 


\section{Abstract}

The Elam School of Fine Arts amalgamated with Auckland University College in 1950, bringing with it a small collection of art books. From these beginnings the Fine Arts Library has developed into the well-funded and reputable arts library that exists today. Throughout its history the Library has supported the Elam School of Fine Arts and later the Department of Art History and has in turn been integrated into and supported by The University of Auckland Library system. This research utilised an historical case study approach to identify and analyse how this web of interconnected relationships has influenced the development, maintenance, and future of a specialised art library.

The findings illustrate that, while the Elam School of Fine Arts and the Department of Art History have experienced considerable curricular and administrative changes, these have not had a significant impact on the efficiency and value of the Library. The Fine Arts Library’s collection and services have consistently supported and enhanced the teaching and research needs of these two entities. Despite accommodation, staffing and funding challenges, the Fine Arts Librarians and Library staff, succeeded in establishing a comprehensive and nationally recognised art library with a strong, vibrant and unique culture.

Keywords: Academic libraries, Art libraries, Elam School of Fine Arts, Fine Arts Library, Library History 


\section{Introduction}

2010 marked the 60th anniversary of the amalgamation of the Elam School of Fine Arts (Elam) into Auckland University College. This significant event provided the catalyst to initiate research into the evolution of the Fine Arts Library (AUEL), which has developed from a small collection in 1950 into the nationally recognised specialist art library of today.

The research provides an historical overview, described in six significant time periods, of the relationships forged between the Library and its major stakeholders — Elam, the Department of Art History (Art History) and The University of Auckland Library General Library (AU). The use of an historical case study approach allows for the assessment of the development of the AUEL through the lenses of information history and organisational culture. Data, information and personal remembrances were compiled and analysed from historical documents, artefacts and by carrying out oral histories.

This research identifies shifts in curricular focus and changes in the organisational structure of Elam and Art History and assesses the resultant effects on the AUEL's services and collections. Factors such as funding, staffing, accommodation and technology are explored and related to the development of the AUEL and its unique culture. The Library's evolving institutional relationship with The University of Auckland Library system (AULS) is outlined and future opportunities for development and realignment posited. 


\section{Purpose Statement}

The purpose of this study is to document the development of the AUEL from 1950-2010, from institutional and cultural perspectives. The themes and patterns identified could provide useful material for those assessing the Library's current needs and the plans for its future strategic development. The past decade has witnessed the burgeoning interest in cultural history and the theory of information history, making historical research about libraries a more robust field of study. As far as it is known, this is the first historical study of the AUEL to be based on contemporary and historical records. Therefore, it will be of interest to both historians of information and library science, special librarians and the wider artistic and art historical community. It also aims to provide a model for further research in New Zealand; which will hopefully encourage other members of the profession to assess the historical development of their own specialist library. The changing role of libraries and information technology in tertiary institutions provides a further catalyst for this research. 


\section{Research Questions}

The study, and especially the data gathering process, is guided by the following seven subquestions.

1. How did the amalgamation of the Elam School of Art and Design into The University of Auckland in 1950 influence the development of a formalised and specialised art library?

2. How has the relationship between Elam School of Fine Arts and the Fine Arts Library developed or changed over the past 60 years?

3. How has the relationship between the Department of Art History and the Fine Arts Library developed or changed over the past 48 years?

4. What role has The University of Auckland Library played in the development of the Fine Arts Library?

5. How has the Library's physical accommodation changed overtime?

6. What defined the culture at the Fine Arts Library? Who lead or influenced this culture?

7. What is the future of the Fine Arts Library? 


\section{Delimitations / Limitations}

\section{Delimitations}

- The researcher has been employed at the AUEL since May 2008 and has her own beliefs and perceptions of the Library's current administration and culture. The researcher, aware of these biases, aimed to provide an accurate, sensitive and professional interpretation of data collected.

\section{Limitations}

- The researcher recognises the significant contribution of other art libraries to specialist library history. However, due to the project's limited time frame and scale the focus is restricted to the AUEL.

- $\quad$ The study focuses on the AUEL in the years between 1950 and 2010. Prior to 1950 the library was an un-catalogued collection and there are few documentary sources to draw on.

- The number of oral histories undertaken is reflective of the amount of time allocated to this research.

\section{Disclaimer}

Opinions expressed here are those of the author and do not necessarily reflect the position of The University of Auckland. 


\section{Literature Review}

The literature review initially aimed to provide an overview of the effect that academic and organisational influences have had on the development of specialist university libraries in New Zealand. Early into the research process the author discovered that little literature concerning the historical development of a specialist academic branch library and the subsequent relationship it had to the faculty and administration has been written from a historical perspective. The author therefore chose the broader fields of library history and information history to provide both a context and to assess the methodological approaches used.

Included in this review of the literature are journal articles, books, and research papers published between 1979 and 2010. These provide a sample of recent work and a selection of seminal studies regarding academic and public libraries from America, Britain and New

Zealand. Research into the history of the library in both pre-modern and modern history is briefly referenced.

\section{Trends in Library History}

The growth of interest in writing library histories in during the 1960s and 1970s, as discussed by Olle (1979), was tempered by the 'amateur' status of their authors. Most were in fulfilment of a library degree, and were written in a popularist style that lacked a clear research methodology. They focused on providing an overview of the organisation or experience of an entire public library system or academic library and only indirectly referenced the development of libraries at branch level. 
The 1970s saw the move away from teaching historical or qualitative research methods in Library and Information Science (LIS) (Black \& Crawford, 2001; Harrison, 1994;

Wertheimer, 2005). Arguably, the current emphasis on legitimising LIS as an interdisciplinary field, through the utilisation of quantitative research, or even the mixed method approach of combining qualitative assessment with quantitative data, has meant that branch or specialist library histories are not being written by LIS students.

The past 15 years has seen an increasing interest in libraries, 'the book' and its collectors, explored through the interdisciplinary lens of social and cultural history. This greater appreciation of libraries, is partly a result of new information technologies reviving the relevance of libraries (D. G. Davis, 2010). Research has focused on two areas. Firstly, the comprehensive history of the 'Library', the book and collectors of both pre-history and modern history (Battles, 2003; Lerner, 2001; Polastron, 2007; Staikos \& Cullen, 2004) and secondly, the development of the public library (Allan, 2008; Black, 1996, 1997). These studies are written by cultural historians who believe that by placing libraries in a broad social, cultural and political context they will find correlations with and insight into wider society.

The field of information history has grown out of this research, with Alistair Black, a major proponent (Black, 1996, 1998, 2006; Black \& Crawford, 2001; Black \& Hoare, 2006; D. G. Davis \& Aho, 2001). Information history is a specialised area of history relating to library and information science. It focuses on the role of information in contemporary society and is the study of the history of print and written culture, including the history of libraries and librarianship, and the history of information management, information systems, and information science (Weller, 2007, 2008). 


\section{New Zealand Library History}

Up until the past decade, New Zealand library history has also been in general written in a popularist style either by history students (S. Wilson, 2006), historians (Barrowman, 1995), librarians (Colgan, 1980; Johnson, 1988; Ronnie, 1993, 2008) or LIS students (Rowan, 1999). Most are also reliant on the primary archival resources held within the institution itself and make little or no reference to other New Zealand or international libraries.

One example of New Zealand LIS research relating to the history of an academic library was written by Rowan (1999). This research paper is a biography of The University of Auckland’s first librarians Alice Minchin and Arthur Sandall. By utilising the field of women’s studies, Rowan’s research differentiates itself from conventional biography and attempts to explore the issues of gender inequality faced by the first qualified female librarian in New Zealand (Hildenbrand, 2000). The research provides historical context and illustrates the use of a solid methodological framework. The Turnbull a library and its world, written by a professional historian, utilises the method of oral-interview-based history (Barrowman, 1995). It provides a thorough assessment of the first 75 years of the Library, placing the Turnbull in the wider historical sphere.

Black argues that the 'institutional anchorage' of such literature whether it is in the form of a popular history or a piece of biographical scholarship limits its appeal (Black, 1998).

Davis and Aho suggest that the undervaluing of this type of research is prevalent in historical circles as well as within the field of library and information science itself (2001). 


\section{Themes}

Despite differences in methodology and purpose, the majority of studies in library / information history utilise three main structures; the thematic chronology, the biography, and the case study.

The chronological approach allows the discussion of trends and events affecting the development of the concept of the library (Hoare et al., 2006; Lerner, 2001; Staikos \& Cullen, 2004). A survey of a time period or epoch not only provides an historical perspective but can be utilised to inform future developments in LIS.

Biographies not only enable the reader to gain an understanding of the individual but the also the world in which the subjects were active (McEldowney, 2006). A biography can incorporate wider themes such as gender (Rowan, 1999) or politics, to shed light on both the individual and the library profession as a whole. A constraint with this genre is that they traditionally have had as their subject Head or University Librarians.

A case study focuses on a single organisation, individual or event. Most academic and public library histories, using the case study method, focus on the library as a whole with only brief reference to branch or divisional libraries. In general, these studies make little reference to the library’s place in the wider social context (Black, 1996).

\section{Summary}

This review identified limitations in the assessment of traditional library histories which up until the mid 1990s were written in a popularist style, lacking a clear research methodology. These publications focused on providing an overview of the organisation or the description an entire public library system or academic library and only indirectly referenced the 
development of libraries at branch level. The literature review also identified the need for more rigorous research in the fields of New Zealand information and library histories.

The recent utilisation of cultural history and of information history has widened the scope and legitimised this area of study. Information history provides the most helpful and fresh methodology and is the most suitable approach when assessing a branch or specialist academic library, allowing for the creation of a grand as well as a granular narrative.

\section{Paradigm}

As outlined in the purpose statement above, this study aims to the gather data about the AUEL relating to its historical context and its development.

This research is intended to sit within a constructivist - interpretivist paradigm (Guba \& Lincoln, 1994; Ponterotto, 2005), which asserts that there are multiple socially constructed realities, where knowledge is gained through understanding the experiences of people. This paradigm also acknowledges the researcher's subconscious values and biases (Pickard, 2007). As stated the researcher is employed by the Library in which they are researching.

The use of a constructivist paradigm is appropriate as it allows for an iterative process whereby new information is incorporated as the study progresses. It also provides the researcher with the flexibility to assess this new area of research and study at both a macro and micro level. 


\section{Theoretical Framework}

This historical study utilises two major theoretical frameworks to help inform and structure the research process. Information history acts as an overarching theoretical framework, while organisational culture elucidates the research questions and allows for the creation of a grand as well as a granular narrative.

\section{Library and Information History}

This area of history relates to library and information science and focuses on the role of information in contemporary society. By utilising social-historical methodology, information history aims to legitimate and place the study of library history into the realm of historical research (Black, 1996, 1997, 2004, 2006; Black \& Crawford, 2001). The pluralistic term “library and information history” coined by Black and Crawford (2001) provides a semantic bridge between the old institutional approach to library history and the wider field of information history, which engages with fields of study outside information science and provides a less restrictive and more interdisciplinary scope (D. G. Davis \& Aho, 2001).

Despite a theoretical framework not being commonly discussed in this area of research it does provide a helpful and fresh approach when assessing the development and role of a branch or specialist academic library.

\section{Organisational Culture}

This historical study utilises the management theory of organisational culture, traditionally viewed as an a-historical area of research (Kieser, 1994). Organisational culture is defined as a set of memories, beliefs and values, in effect, collective understandings that have 
developed overtime and have become imbedded into the everyday running of an organisation. It is both the explicit rules and regulations and implicit knowledge and norms that are transferred to new staff (Schein, 2010; Trice \& Beyer, 1984, 1987). “Culture has two basic components: (1) its substance, or the networks of meanings contained in its ideologies, norms, and values; and (2) its forms, or the practices whereby these meanings are expressed, affirmed, and communicated to members” (Trice \& Beyer, 1984, p. 654).

Kieser (1994) argued that historical research can be used by researchers of organisational theory as it can teach valuable lessons, highlight patterns in organisation theory and help practitioners to identify and make better choices. Some students of organisational theory have argued that Kieser has overstated the need for historical research in organisation science (Goldman, 1994). However, while historical and cultural research paradigms differ significantly this theory will be helpful in identifying the broad articulation of organisational culture.

\section{Methodology and Data Collection}

The use of the qualitative methodology of historical research allows the researcher to interpret and understand the data or information whereas quantitative study provides statistical facts without always providing supporting contextual evidence. A qualitative investigation of human relationships, through the use of archival resources and oral histories helps to provide context and a deeper social value. 


\section{Historical Case Study}

This study utilises an historical case study as its core methodology (Gorman, 2005; Shep, 2005). It also employs elements of social and cultural history to understand the relationship between the AUEL and a number of institutional partners (Danto, 2008). This methodology allows the researcher to read between the lines of historical narratives and unravel the truths held within a range of primary and secondary sources (Pickard, 2007). Historical research is based on the researcher's interpretation of the data and as a consequence the researcher must be aware of their own biases and also the participatory role they play in the research process (Pickard, 2007).

\section{Sources of Data}

The sources of research involved the undertaking of oral histories, assessing and analysing primary and secondary archival documents as well as the broad category of realia which include artifacts and ephemera (Black \& Hoare, 2006; Danto, 2008).

\section{Primary Sources}

The AUEL houses the Elam Archive. This collection has a large number of administrative documents that deal with the running of the School, some of which relate to the Library. A range of primary documents and resources from The University of Auckland Senate, Property Services, and the AU Special Collections were utilised.

\section{Secondary Sources}

A history of the Elam (1890-1983) was written by Franks in partial fulfilment of the Masters of Art History from The University of Auckland (1984). Importantly Franks recorded oral histories with Elam staff and students, including former Fine Arts Librarians 
(G. H. Brown, 1983; Richards, 1983a). There have also been articles, exhibition catalogues and ephemera that discuss the history of the School including those celebrating the centenary of The University of Auckland (Elam School of Fine Arts, 1983), the centenary of the School in 1990 (Binney, 1990; Daly-Peoples, 1990) and most recently the 60th anniversary of the School within The University of Auckland (Elam School of Fine Arts, 2010, July; Wolfe \& Elam School of Fine Arts, 2010). While they provide some important context they make only a passing reference to the Library and its wider relationship with the University.

\section{Oral History}

Oral history interviews with staff members were conducted (Bryman, 2008). The in-depth interview was chosen as one of the main methods for data collection rather than other methods because as Yow succinctly argues, "Oral history testimony is the kind of information that makes other public documents understandable” (2005). Interviews also help to fill some of the gaps and contest some of the "official organisational narratives" (Basten, 2011).

The semi-structured interview schedule utilised, enables a multiplicity of remembrances or counter narratives to be expressed (Bryman, 2008). It focuses on the interviewee, whose subjective responses can introduce and encourage deeper readings of documentary resources.

For reflections on the Library's earlier development the research relied on the existing oral history interviews held in the Elam Archive. However, the oral histories completed by the researcher formed the basis of most of the remembered history. 


\section{Selecting Oral History Participants}

The original selection of the interview participants was based on several criteria. Each participant was chosen as they had an in-depth understanding of how the AUEL had developed from either a practical perspective or a strategic viewpoint. The sample group interviewed represent a range of experiences and roles and their period of employment covered a significant proportion of the AUEL’s history.

Each of the prospective participants was sent a letter introducing the study and its aims and participant information and consent forms (See Appendices 2 and 3). All four individuals responded and all but one agreed to be involved in this study either by being interviewed or by submitting responses in writing. The individual who did not participate identified a former staff member who was willing to provide a written response.

The researcher subsequently noted that the sample group did not include a part-time staff member or a Library Assistant who had not advanced into a senior or managerial position. A former staff member, who fitted these criteria, agreed to be interviewed.

The four participants interviewed were:

- Valerie Richards (Fine Arts Librarian from 1965-1990)

- Jane Dodd (Full-time and part-time Library Assistant and Archivist 1987-2007)

- $\quad$ Lynley Stone (Deputy Fine Arts Librarian 1990-1994)

- Jane Wild (Manager of the National Institute of Creative Arts and Industries Libraries and Special Collections 1999-present)

See Appendix 4 for brief participant profiles. 
Written responses were provided by:

- Gail Keefe (Library Assistant - Assistant Librarian - Fine Arts Librarian 1987-2007)

- Nicole Jackson (Library Assistant - Deputy Librarian - Subject Librarian

Prior to the interview each participant was sent a schedule of questions, which was utilised to structure each session (Appendix 5). The interviews lasted between 60 and 80 minutes and were documented using an mp3 digital recorder. Three out of the four interviews were conducted in a meeting room at The University of Auckland City Campus, with the final being a phone interview.

As there were fewer documents pertaining to the relationship between the Library and Art History, a former and current Head of Art History were contacted. Elizabeth Rankin, Head of Department in the late 1990s and early 2000s provided written responses to a limited set of questions (Appendix 6).

\section{Data Analysis}

Analysis of historical data is an iterative process (Droysen, 1893). A number of data analysis techniques were used to collect, evaluate and prioritize empirical material or data.

Hermeneutics is the broad study of interpretation and understanding. Hermeneutic analysis focuses on the interpretation of textual data in its context, both present and past. This study utilised both concepts of hermeneutics and was a valid approach when assessing the empirical material created by historical research (Mercier, 1994). 
Hermeneutics helped to assess both textual data and the project's oral histories. The oral history interview allowed the researcher to account for how people relate to the past experiences through spoken word (Hyde, 1980). The interviews were not focused on collating and collaborating facts and dates or providing evidence for a theoretical argument. Each interview aimed to obtain information on the working life of the individual and to capture their experiences at and memories of their time spent at the AUEL (Haynes, 2010; Wall, 2010). The analysis of the oral history interviews was a complex task (Blatz, 1990) and due to time constraints only pertinent sections of the oral history interviews were transcribed. Methods from oral history research and narrative analysis were utilised to interpret each recording (Chamberlain, 2006).

"Secondary analysis involves the utilisation of existing data, collected for the purposes of a prior study, in order to pursue a research interest which is distinct from that of the original work” (Heaton, 1998). This includes quantitative and qualitative data. Resources including previously conducted oral histories and other organisational records such as audits and surveys, notes and manuscripts were reassessed to find additional data and themes that may not have been identified in the original research (Bryman, 2008; Goodwin \& O'Connor, 2006).

These techniques as well as the intuition of the researcher helped to identify patterns and themes (Bryman, 2008; Pickard, 2007). This enabled a holistic view of the relationships between Elam, Art History, AU and the AUEL. The analysis of the documentary data was not directed by a preconceived model. It was developed and created in a continuous discourse with the available historical data (Kieser, 1994). 


\section{Limitations of Methodology}

During the interview process a number of shortcomings were identified:

- the oral history schedule was written in past tense which biased it towards past staff members.

- the range of jobs that had been held by the interviewees meant that questions that focused on either the practical or managerial tasks were not always appropriate or relevant to the experience of the individual participant.

- the questions that focused on the academic effectiveness of the Elam and the Art History could not be answered by the interview participants.

Therefore, while remaining focused on a set of general topics, the research would have benefitted from including questions more tailored to the experiences and knowledge base of the individual respondent.

The analysis of the oral histories and primary and secondary sources provided a limited number of references to the rites and rituals of the organisation. Consequently the researcher could only explore the concept of organisational culture on a superficial level.

At the end of the research and interview phase a revaluation of the research questions was carried out. One of the questions that had focused on how the size and growth of the collection had affected the physical space was streamlined to focus on how the building has changed overtime. An additional question on the culture of the AUEL was included to better reflect the use of organisational culture as a theoretical mode 


\section{Chapter One: 1950-1961}

\section{The Elam School of Fine Arts 1950-1961}

On the 15th January 1949 a fire destroyed the School and its Library (Franks, 1984; "Heavy loss in fire," 1949; Tyler, 2010) and a year later the Elam School of Fine Arts became a 'special school’ under the jurisdiction of the Auckland University College Council (Auckland University College, 1947; Education Department \& McMurtrie, 1948; Sinclair, 1983). This integration significantly changed the School's roll and demographic (Fisher, 1955). Elam’s new academic status required the reassessment of its curriculum especially in regards to art theory. Fairburn became the first Lecturer in the History and Theory of Art in 1951, the only one of its kind in New Zealand (Fairburn, 1955). The School's shift into a more academic world opened up a range of opportunities, including the development of an academic art library.

During this period former students and staff described the School's teaching style as rigid, hierarchical and conservative with the curriculum focusing on draughtsmanship, modelling and design (Auckland Society of Arts \& Fine Arts Committee, 1949; R. Ellis \& Tapper, c.1983; Fairburn, 1944-1945, 1945; Saunders, 1983). In the 1950s Elam’s lack of vision, due in part to the approach taken by its Head, Archibald Joseph Charles Fisher, restricted it from developing into a reputable, modern and innovative organisation (Franks, 1984). 


\section{Newton West}

During the 1950s the School was housed at two sites - prefabricated buildings on the School's former site in Symonds Street and in the grounds of the former Newton West School on the corner of Brisbane Street and Great North Road, Grey Lynn, where the Library was situated (Figure 1). Elam’s poor infrastructure and working conditions were widely discussed (Vaassen, 1962; W.R., 1958) and were best expressed by Fisher (1955):

In general, I consider that the poor position in which we have found ourselves, since the fire of 1949, in regards to buildings and equipment has acted as a severe discouragement to those contemplating enrolment, and have inevitably lowered the morale of the School. (p. 2)

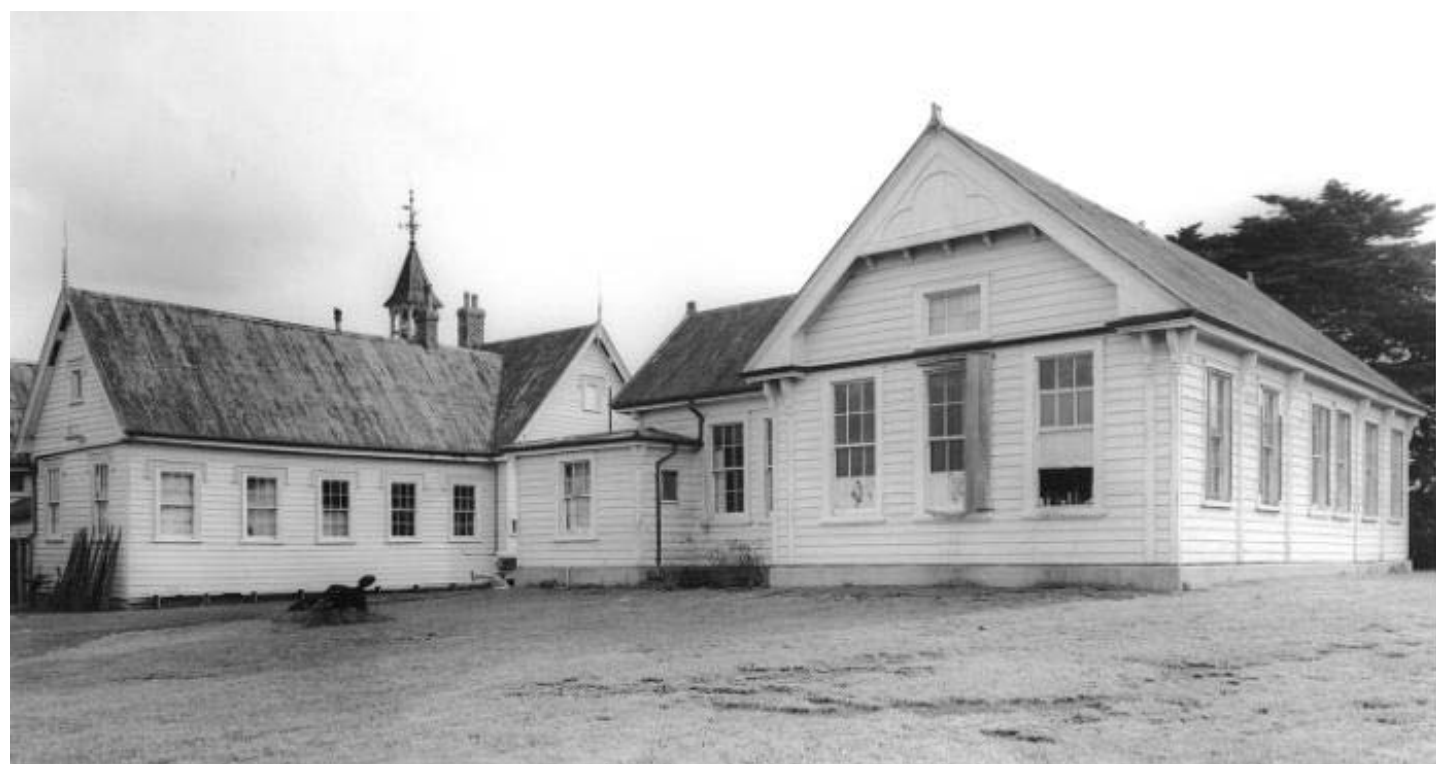

Figure 1. Elam School of Fine Arts, Newton West site (1963)

Throughout its 60 year history within The University of Auckland, Elam has faced many challenges in terms of its buildings and infrastructure. The various physical incarnations of 
the AUEL can be identified as an artifact of the organisational culture (Schein, 2010), a visible manifestation of the Library's culture. The analysis of the Library's physical space over time helps to identify the way in which the organisation was perceived, supported and valued (Schein, 2010). It also provides an entry point into the way the Library functioned. The University’s inability to upgrade or construct new premises for the School meant that staff and students cultivated a culture of defiance in the face of adversity (Macpherson, 1999a, 1999b). It was also difficult to create a community atmosphere as the School was split between two sites (Catt, 1951; W.R., 1958).

\section{The Library 1950-1961: The Lawless Years}

Internationally, the development of professionally administered art libraries began in the early 1960s (D. L. Smith \& Baxter, 1965). A number of art library profiles and histories include references to library collections prior to this decade. However, they largely describe them as small collections run by non-professional librarians (Aulton, 1970; Leja, 2006; Valmestad, 2006; Willmot, 1970).

In 1950 the AUEL was identified as a Departmental Library (Tamaki Planning Committee, 1951). This status differed from a Divisional Library in terms of funding and administration. Each Departmental Library, within a Special / Professional School, was run with minimal support from the AU. The School decided on the funding allocated to the Library each year. The items would then be purchased, catalogued and processed by AU (Sandall, 1950a, 1950b). By 1952, University Librarian, Arthur Sandall, described the new Departmental Library as "still feeling their way to some extent and I suggest need to gather 
momentum in selection and acquisition of books and reproductions” (Auckland University College, 1952, p. 2).

The Newton West library covered 624 square feet (Education Department \& Elam School of Fine Arts, c.1949). A floor plan drawn by Sandall (Figure 2), illustrates his recommendation for rearranging the Library (Sandall, 1951).

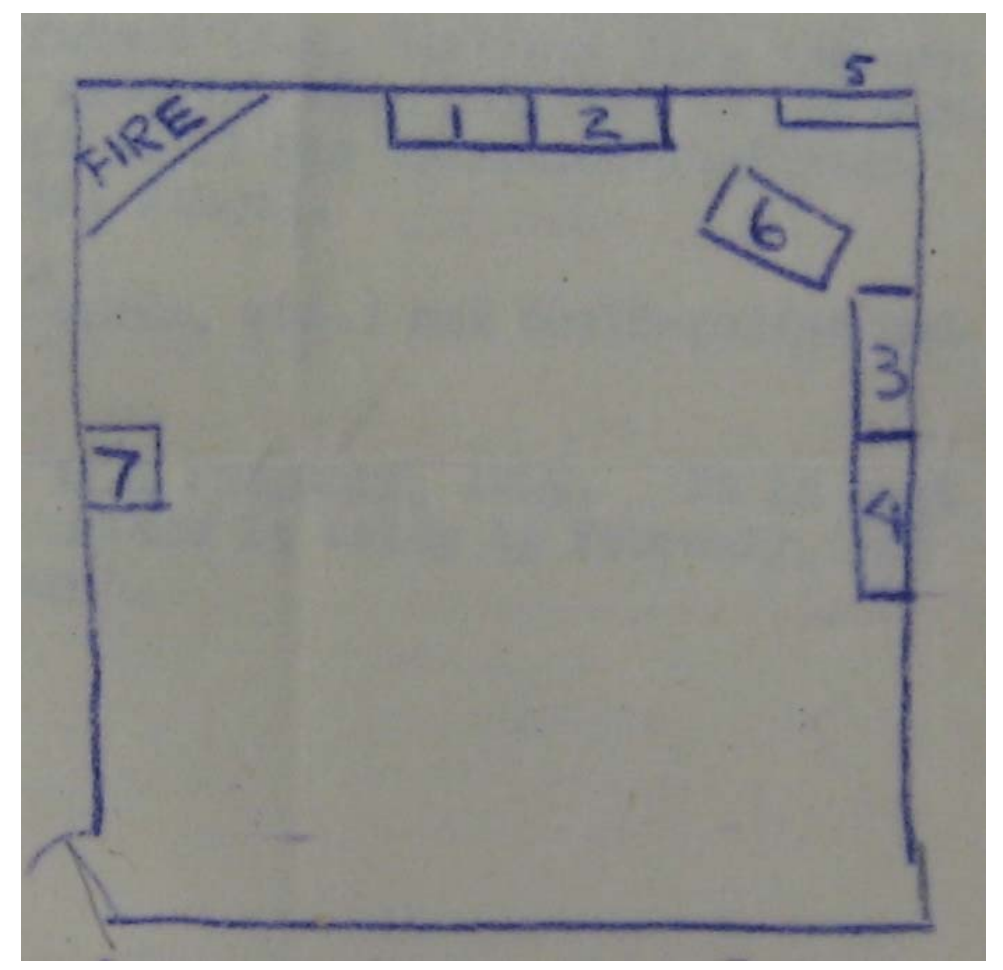

Figure 2. "Proposed layout of library at Newton West" $1,2,3,4$ are existing units of shelves; 5 small set of "process" shelves...; 6 desks...; 7 cabinets” (Sandall, 1951)

The letter in response to these suggestion states "that the question of the lay-out of the room be left in the hands of the Lecturer in the History and Theory of Fine Arts” (Fisher, 1951). Images from the 1958 and 1962 prospectuses convey the limitations of the space, with the lack of free standing shelves restricting the number of books the reading room could accommodate (Figures 3 and 4). 


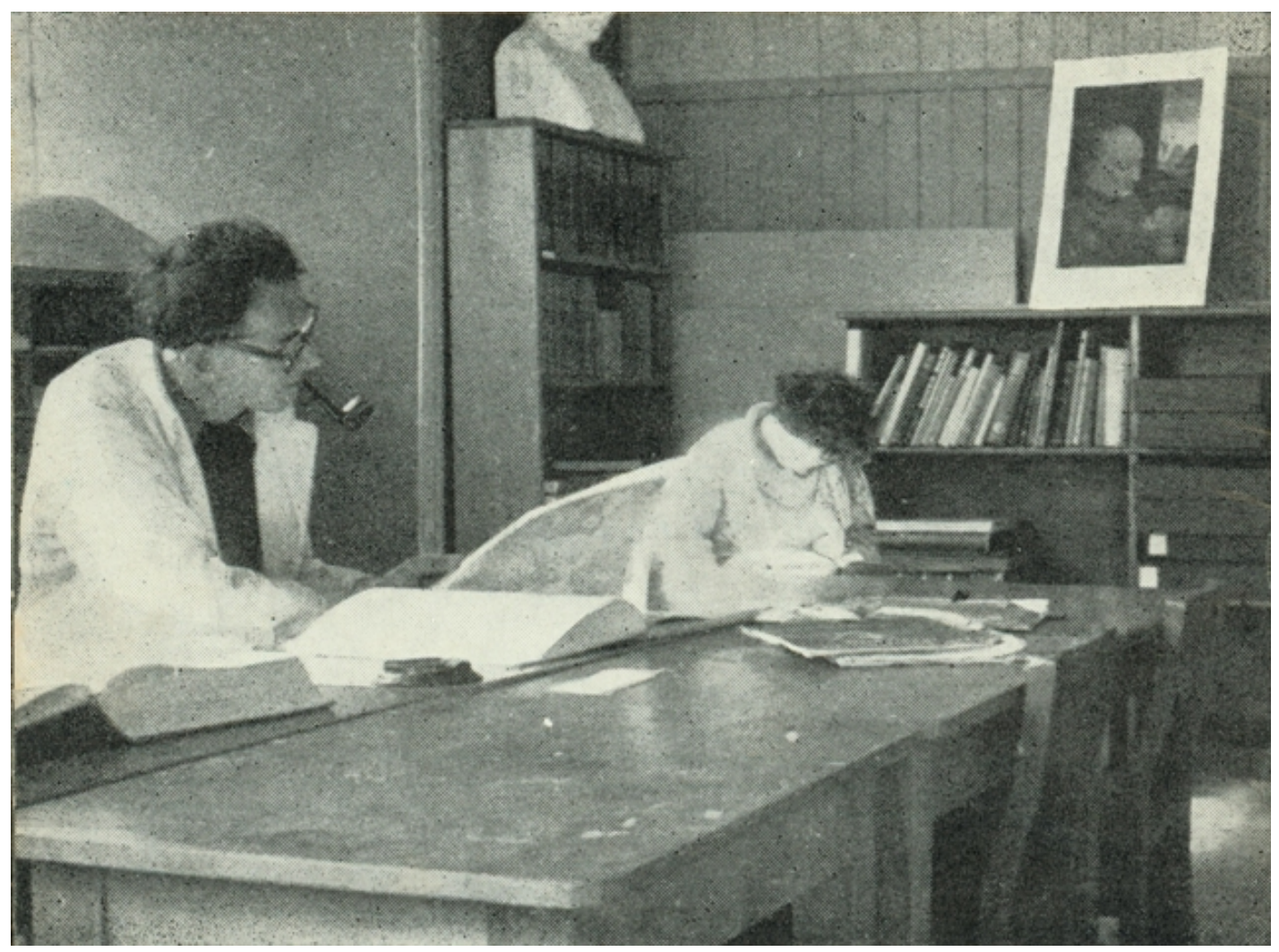

Figure 3. View of the library at the Elam School of Fine Arts, Newton West (1958)

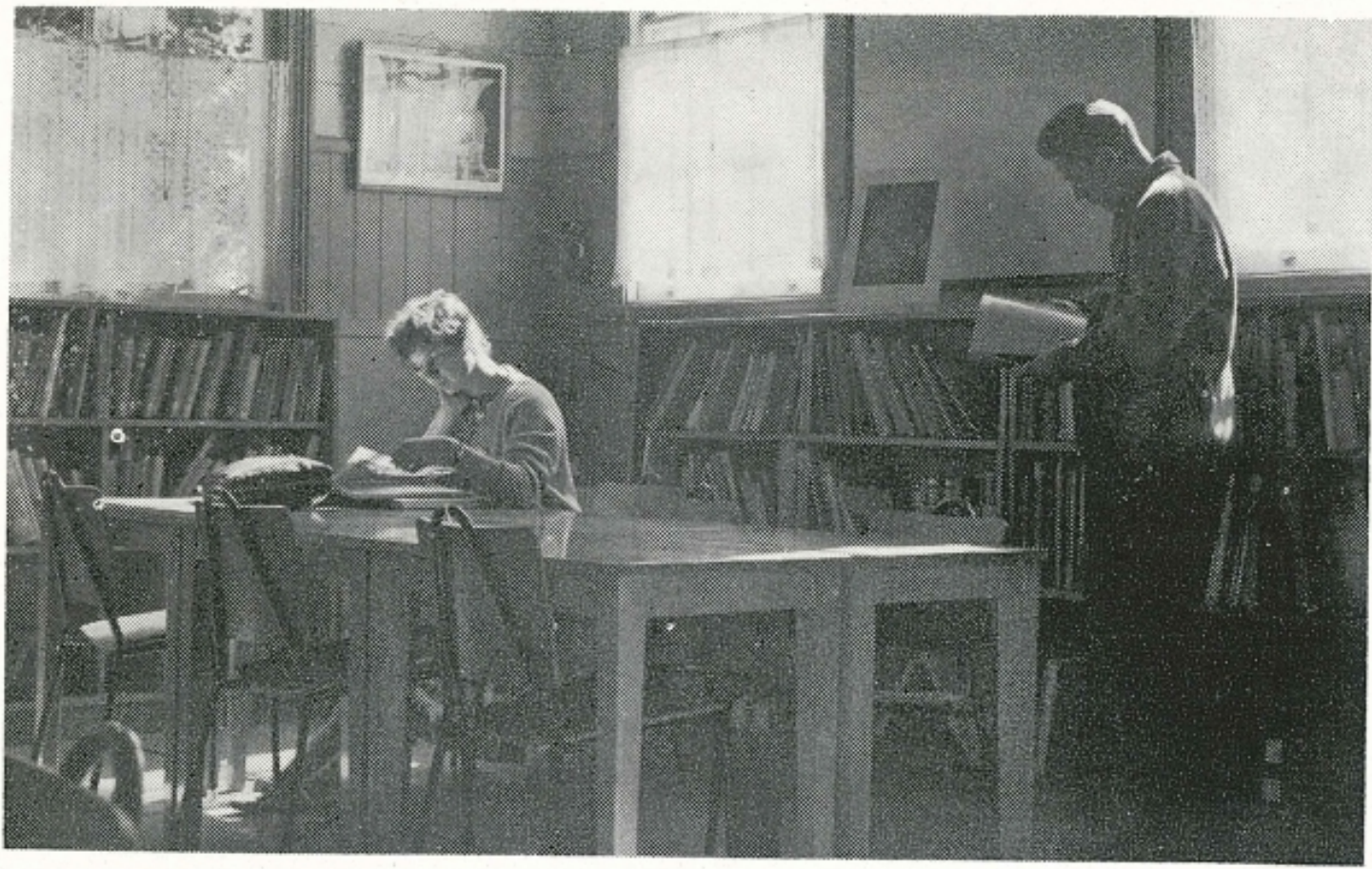

Figure 4. View of the library at the Elam School of Fine Arts, Newton West (1962) 
Statistics kept during June, July, August 1952 showed that the library issued an average of 17 books per week (Fine Arts Library Sub-Committee, 1952). The space was also used as a lunch room where students were permitted to smoke (Fine Arts Library Sub-Committee, 1952). The Library as a physical space was treated as a multi-functional area. As suggested by Smith and Baxter "In colleges which lack adequate common rooms and leisure facilities, students...may come to regard the library as a rest-room or meeting place” (1965, p. 6).

Between 1951 and 1961 the Library was principally administered by the secretarial office staff (Sandall, 1950a). Elam provided funding for a temporary student / librarian at a rate of $£ 1$ per week in 1951 (Elam School of Fine Arts, 1950). The Library was open from 10am to 1pm (Sandall, 1951), with Elam staff able to access the library outside of these hours by obtaining a key from the office this arrangement continued to 1964 (Beadle, 1964; Fine Arts Library Sub-Committee, 1957).

An Elam lecturer, Robert Ellis described the collection of art books at Newton West during his earlier years at the School (from 1957 until Archie Fisher's death in 1959); “the art library consisted... [of]...one locked cupboard and in that cupboard were about 40 or 50 books, those 40 or 50 books nothing later than about 1850” (R. Ellis \& Tapper, c.1983). This statement underestimated the number of books held by the Library, as shown by the acquisition records (Complete orders 1951-1960). However, the Library collection would not have exceeded fifteen hundred books, periodicals and visual resources (Beadle, 1962). This situation partly reflected the state of the New Zealand book trade where licensing restrictions limited the importation of books between the 1930s and the early 1960s (Craccum Reporter, 1963; R. Ellis \& Tapper, c.1983; McKeon, 2001; Preston, 2001). 
The Library’s grant between 1950 and 1960 was $£ 300$ per annum (Fisher, 1951). This was augmented, up until 1954, by two Government fire loss grants of $£ 355$ 12s 10d and $£ 500$ respectively (Fine Arts Library Sub-Committee, 1954). These grants were utilised to “purchase an equivalent collection of representative contemporary publications” (C. G. S. Ellis, 1953). The list of 'Fire Loss Replacements', of books, artworks and serials, provides an insight into the collection's redevelopment (Complete orders 1951-1960; C. G. S. Ellis, 1953; Registrar Auckland University College, 1952). Acquisition records show a traditional and conservative collection of art books on ancient and renaissance art, drawing and modelling and monographs on artists such as Augustus John, a favourite of Fisher (R. Ellis \& Tapper, c.1983).

Elam's establishment of an AUEL sub-committee confirms that although the collection was not a large one, the School was committed to its successful management (Fine Arts Library Sub-Committee, 1952, 1956, 1957, 1960, 1962). The Library’s acquisitions were chosen by both the lecturers and the Librarian, who was never referred to by name. Along with books purchased from Progressive Books, Technical Books, Whitcombe and Tombs, Paul’s Arcade and Roy Parson’s, the Library also acquired prints for the teaching collection. A slide collection, developed in the 1950s, was initially catalogued by and held in the AUEL.

\section{Planning the New Library}

In 1958 the Army, on whose land the Newton West site was situated, requested its return. Ellis discussed the School's current and previous accommodations and refers to a schedule of new buildings at Tamaki in 1952 with the Library to occupy 400 square feet (R. Ellis, 1963). This did not eventuate and it took a further decade to identify an appropriate site. 
This indecision was arguably a consequence of the University Council's ongoing "site row" (Sinclair, 1983, pp. 223-240).

Funding for a new Fine Arts school building was approved by the University Grants Committee in the late 1950s and tenders were invited in August 1960 ("£145,000 arts school," 1960; "New School of Fine Arts," 1960; "Tenders for art school," 1960; "Tenders: New School of Fine Arts, University of Auckland," 1960). The death of Fisher in 1959 "left a power vacuum” until the appointment of Professor Paul Beadle in 1961 (Franks, 1984, p. 41). Without a strong leader the project was characterised by dissention between Elam’s various departments (Beadle, 1963; Franks, 1984), reflecting the presence of a number of micro-cultures (Macpherson, 1999b).

The new School was designed when the Library was still a Departmental Collection and the brief reflected this. The 1958 building specifications written by Fisher, limited the School to 80 students and the Library to 725 sq feet, 100 feet of which is given to a work area for the Librarian. The report also envisaged that the Library would hold a maximum of 25 readers per hour during peak hours (Fisher, 1958). Sandall was consulted and drew on his experience and knowledge gained from visiting American University Libraries (Sandall, 1956) and suggested that it should cover 1295 square feet (R. Ellis, 1963). In the main Sandall's recommendations were incorporated in the design and size of the new Library, but little effort was made to investigate the design of other specialists libraries.

Interestingly, Elam and the architects need not have gone far to view a new and well designed academic branch library - the University’s Architecture Library. This project completed in 1957, was successful for the following reasons. Firstly, the Librarian-in- 
charge was given the opportunity to design the Library space and secondly, the School had provided generous financial support (Cumming, 1958, 1968).

In addition, to this local physical exemplar a number of articles and books had been published in New Zealand and internationally during the late 1940s and 1950s on the design of library buildings (Cooperative Committee on Library Building Plans \& Burchard, 1949; Fussler, 1947; Mercer, 1953; New Zealand Library Association, 1949).

\section{The 'Main Library'}

The Auckland University College’s student population had increased dramatically throughout the previous three decades and the AULS was not provided with financial and infrastructural support to keep pace (Sinclair, 1983). This was consistent with the situation throughout New Zealand where no Library could have been described as holding a complete and self-contained collection (Sandall, 1952). During this time the cost of books continually outstripped the AU's allotted funds.

In 1956 Sandall travelled to America and visited a number of academic libraries. He discovered that Auckland’s situation was comparable to a medium sized American university, in student numbers and subjects taught. "We differ on the whole, however, in having fewer books, fewer teaching staff, poorer equipment and less money” (1956, p. 1). He also noted that other than very large institutions, the majority of American university libraries were based on a centralised system.

In comparison the AULS was comprised of a number of satellite subject-oriented collections which had developed on an ad hoc basis (R. R. Walsh, 1969). Sandall believed 
that these departmental collections should be supervised by trained staff that were part of the wider Library organisation (Johnson, 1988). 1961 saw the first named reference to a library assistant at Elam. In 1961 annual report thanks are made to a 'Miss Huysmans' a secretary at the School being "loaned" by Elam to manage the Library collection (The University of Auckland Library, 1961a, p. 4). While a list of all Library staff of the same year attributes the position of Assistant-in-charge part-time to a 'H.M. Huismans [Miss]' (The University of Auckland Library, 1961b).

1961 also heralded the establishment of a Chair of Fine Arts, giving the School faculty status. Professor Paul Beadle was appointed in this position. During his first year Beadle wrote a number of letters in regard to the Library, including one to the Chairman of the Library Committee, "I wish to bring to your attention the serious delay in purchasing and cataloguing. In February I selected approximately 25 volumes at Paul’s Bookshop...They duly arrived in mid-August” (Beadle, 1961). Beadle and Sandall both advocated for the appointment of a trained librarian (Sandall, 1961)

\section{Culture}

The organisational culture of the School from the-mid 1920s up until the late 1950s was moulded and maintained by Fisher, Director from 1924 until his sudden death in 1959 (Franks, 1984). Schein explores the interconnected nature of culture and leadership arguing that "culture is ultimately created, embedded, evolved, and ultimately manipulated by leaders” (Schein, 2010, p. 3). Fisher enforced a structured curriculum that did not promote artistic freedom or self expression (Sinclair, 1983; Twiss, c.1983). Despite achieving his goal of gaining tertiary status for the School, Fisher failed to be a creative champion and 
was content to continue the technical school trajectory of the previous 50 years (Franks, 1984).

Throughout this time the School in effect 'owned' the Library with the dominating and traditional ideas of Fisher being reflected in the collection. By the end of the decade this resulted in a stagnant curriculum, a very limited collection of art books and an ill-conceived building project. Elam's new faculty status and the appointment of Beadle was the beginning of a new era (Franks, 1984). 


\section{Chapter Two: 1962-1976}

\section{The Banner Year}

1962 was an important year for both the AUEL and The University as a whole. The Colleges of the University of New Zealand became autonomous entities (Sinclair, 1983) and the AUEL received its first full-time and trained Assistant-in-Charge, Mrs Desma Butler (née Russell) (Beadle, 1962; Johnson, 1988; The University of Auckland Library, 1961a, 1962b). The Library finally moved into its new premises on the 21st of December (The University of Auckland Library, 1962a).

The meeting of the 14th of February 1962 is the first acknowledgement of the AUEL as part of the wider AULS (Fine Arts Library Sub-Committee). This meeting posited the need for a larger grant and a stronger relationship between the divisional libraries. In 1962 cataloguing and acquisitions were reassigned to the AUEL (The University of Auckland Library, 1961a) and its total budget increased from $£ 666$ in 1961 to $£ 1179$ (The University of Auckland Library, 1962a).

\section{Elam School of Fine Arts, Whitaker Place}

Elam’s was the first project in the University’s £26 million building programme. The new site was on reserve land below Symonds Street. The project was funded by the University Grants Committee in Wellington and the design and building was directed by the Works Department, also Wellington based. The architects, Messrs Massey, Beatson, Rix-Trott, Carter and Co. won the tender. 
It was unfortunate that by the time Beadle was appointed the designs for the Whitaker Place site were near completion. Beadle had not been able to stamp his mark and asserted that "the whole conception seems to lean heavily on what could be called an almost standard institutional style, adopted without thought for the nature or character of a school of art” (1963, p. 6). This assessment was mild in comparison to the judgements expressed by Kurt von Meier, Elam’s Lecturer in the History and Theory of Art (von Meier, 1963a, 1963b, 1963c; W. D. Wilson, 1963).

Publicly and within the architectural profession the building of the School was identified as one of the most important building projects in New Zealand during the early 1960s with reviews in such publications as Home \& Building ("Big city buildings near completion," 1962; "Elam School of Fine Arts," 1963). See Figures 5 and 6.

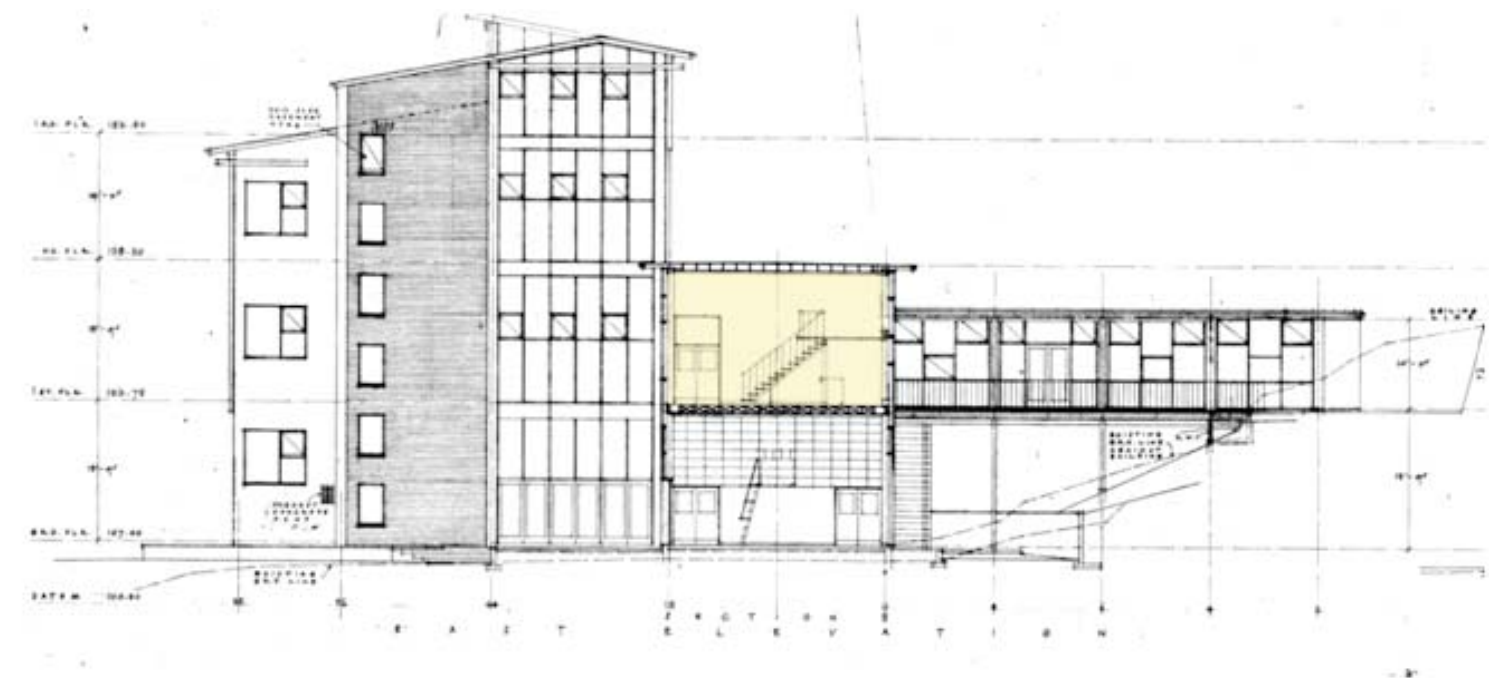

Figure 5. Elevation of School of Fine Arts at Whitaker Place (1960). Highlighted area showing library in relation to the rest of the Fine Arts buildings 


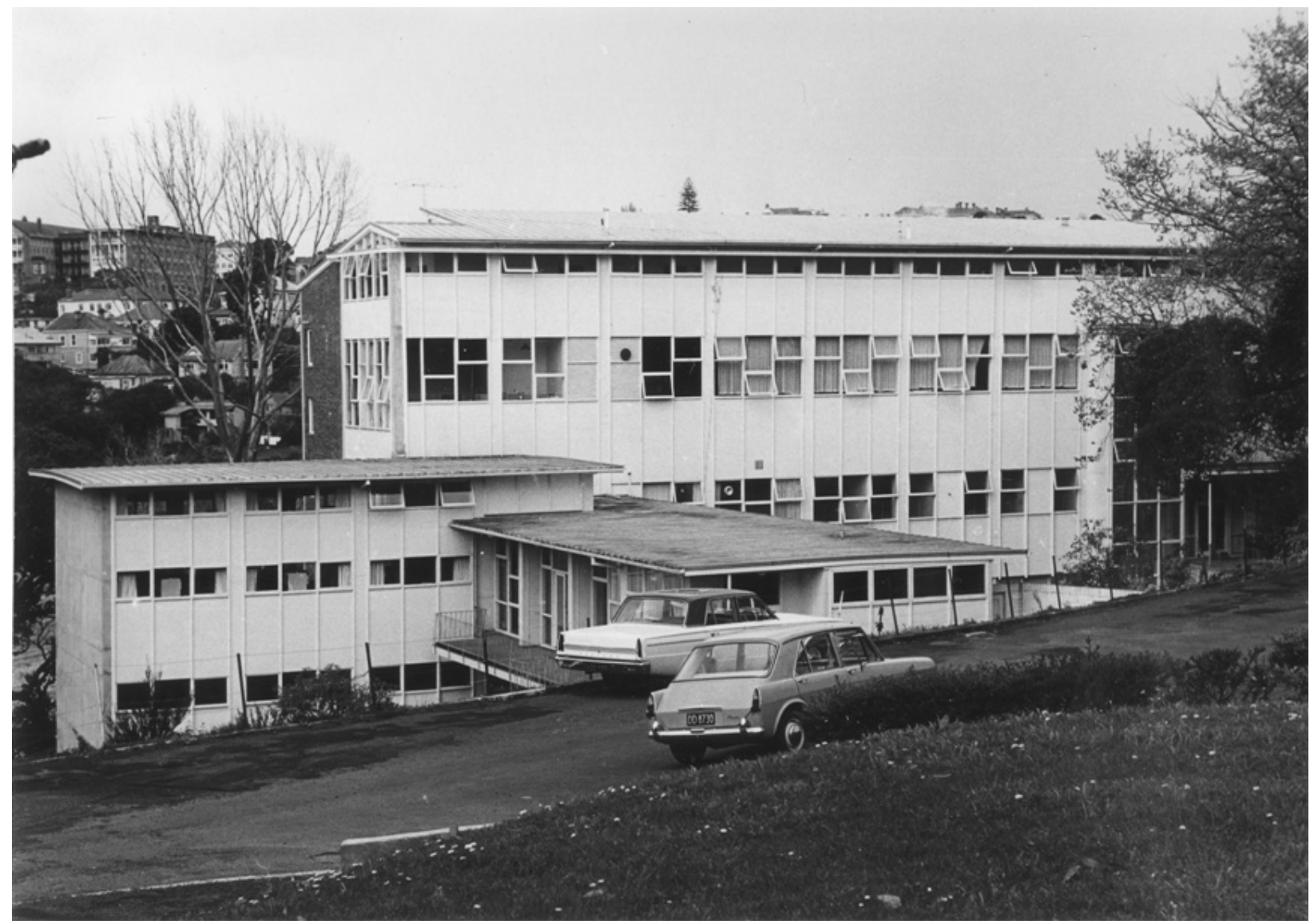

Figure 6. Administration wing (right) and Library (left) at Whitaker Place (1968)

\section{The New Library}

The new Library (Figure 7 and 8) was occupied in late 1962 but as Sandall's frustrated comment attest the size of the AUEL was not as generous as the Library administration would have preferred (The University of Auckland Library, 1962a, 1963): “in its present form may hold up to 10,000 books at the most and some 25 readers. Nevertheless this is handsome by comparison to the past...” (The University of Auckland Library, 1962a, p. 9). The space provided was to limit the success of any future physical reorganisation. Beadle identified other limitations including the awkward positioning of a number of architectural features as illustrated in Fig 8 (Beadle, 1963). 


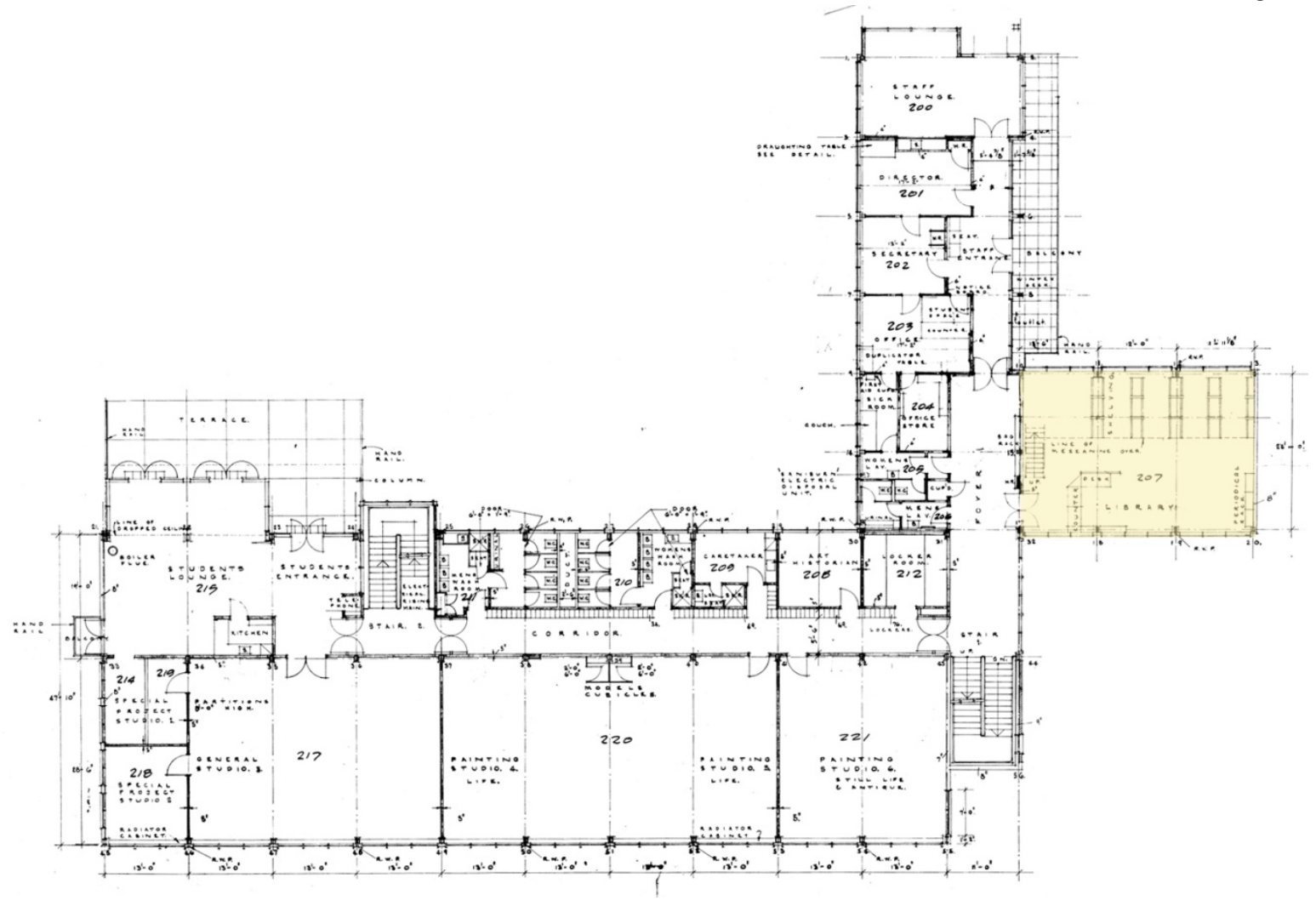

Figure 7. Plans of Elam School of Fine Arts at Whitaker Place (1960), Fine Arts Library highlighted in yellow

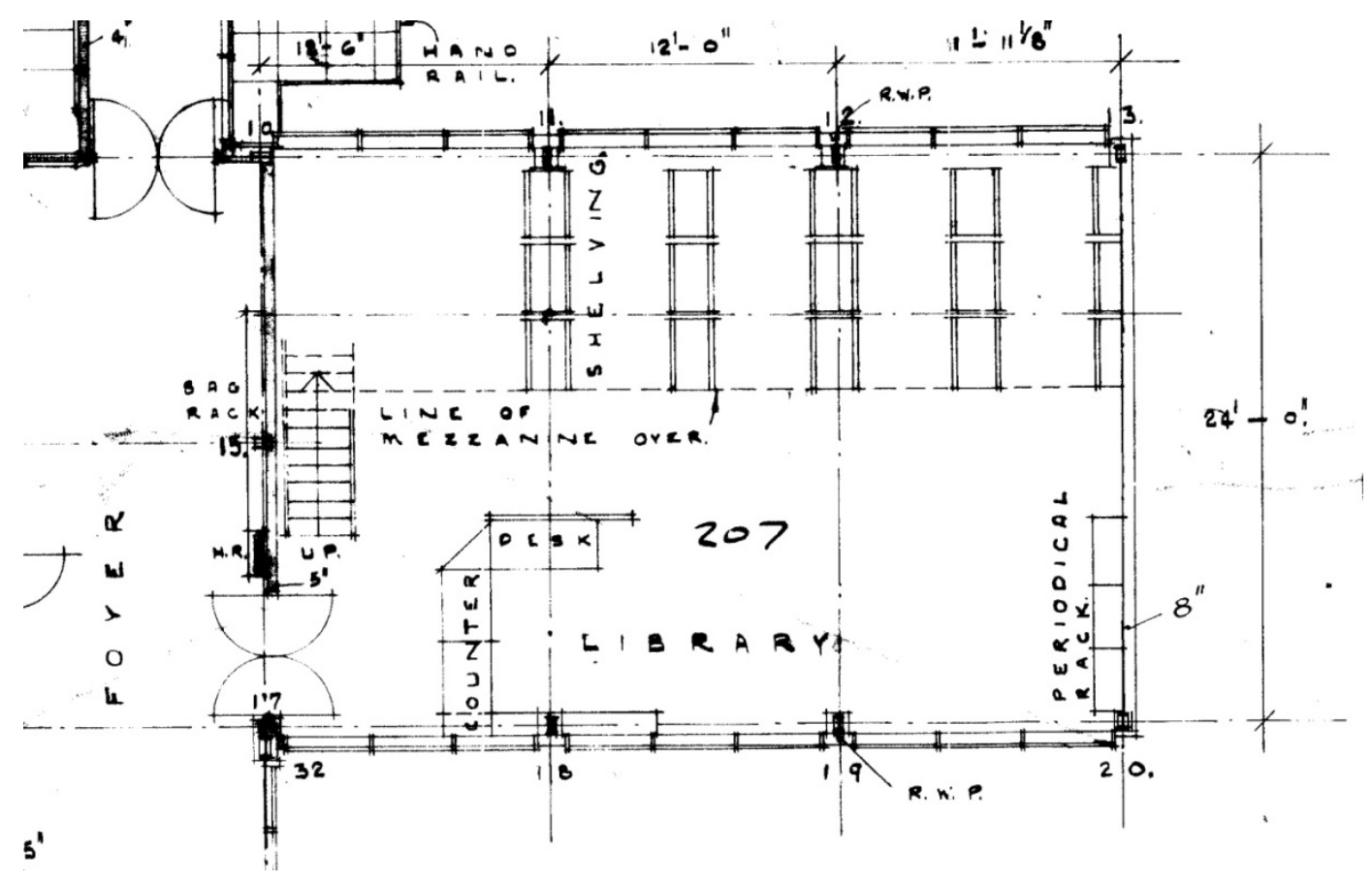

Figure 8. Original layout of the Fine Arts Library at Whitaker Place (1960). Note the counter / desk is directly in front of the entrance (bottom left). While the stairs up to the Mezzanine are also positioned in close proximity to the entrance 


\section{Professionalisation of the AUEL}

The appointment of a professional interim Librarian (Butler) in 1962 meant the Library was no longer staffed by members of the Elam office. However, the arrival of Gordon $\mathrm{H}$.

Brown, the Library's first permanent Assistant-in-Charge in June 1964 significantly shifted the relationship the School had with the Library. As Brown suggested 20 years later this administrative separation provided a certain amount of freedom, “you were divorced up to a point from the politics of the art school...” (G. H. Brown, 1983). This appointment coincided with the increased number and increasing significance of art libraries on the international stage (Pacey, 1980c; D. L. Smith \& Baxter, 1965).

The three most significant issues Brown encountered during his 17 months in sole charge were the Library's spatial constraints; the quality of cataloguing and the insufficient staffing levels (G. H. Brown, 1965). The historically inconsistent cataloguing provided by AU meant that books on the same topic were catalogued in a number of areas (G. H. Brown, 1983). Brown moulded the 700 class of the Dewey Decimal Classification (DDC) to re-catalogue the collection, consistent with the approach take in other contemporary art libraries (Brill, 1970; A. Davis, 1969; Phillpot \& Doran, 1970; Ramsden \& Harrop, 1970; Stracey, 1970; Walker, 1970). The AUEL focused on art theory and the fine arts, which at that time was largely limited to painting and sculpture from international artists (G. H. Brown \& Fine Arts Library, 1964; Broxis, 1968; Neal, 1973).

The Conditions of Employment from 1963 suggested that "the volume of work will be quite within the ability of one person during 1964” (Kirkness, 1963). This was not however the reality given the increase in enrolments in History and Theory of Fine Arts and the 
Diploma of Fine Arts by 62\% and 30\% respectively (Beadle, 1965b). In 1965, due to staff restrictions the Library reduced its hours from 31 to 17 hours weekly.

Issues between the Library and fledgling Department of Art History also added to the challenge. The Americans, von Meier and Arthur Lawrence (Lawrence, 1965) were appointed Lecturers in the History and Theory of Fine Arts in 1962 and 1963, respectively. The History and Theory of Fine Arts had been included as a Bachelor of Arts unit within the Faculty of Arts in 1963 (Craccum Reporter, 1963; The University of Auckland Library, 1963). Brown remembered that due to “ambiguous” (G. H. Brown, 1983) wording in his job description, von Meier, believed he was responsible for ordering the Library’s books, when in reality he had only been asked to recommend items for purchase (Sandall, 1963). Not only did von Meier order books without the Library’s permission, he selected books with no relevance to the fine arts or art theory. This meant that Brown was forced to return each item that von Meier suggested, adding to his already significant workload (G. H. Brown, 1983).

During the 1960s the shortage of trained librarians was a significant issue for all New Zealand libraries (Barrowman, 1995; The University of Auckland Library, 1961a). So when Brown submitted his resignation in June 1965, Valerie Lockwood (who will be referred to by her married name Richards), a trained Library Assistant at the Architecture Library (Cumming, 1968), who held a New Zealand Library Association (NZLA) Certificate was the prime candidate. Richards recently recalled that she was in effect "given” the position of Librarian-in-charge by Sandall (personal communication, April 8, 2011). Richards was supported by a Library Assistant, Marion Tulloch, who remained in the position until late 1967. 


\section{Richards and the Building}

The initial design of the Library lacked a number of services and facilities including heating and power outlets (Beadle, 1963). In addition, the amount of floor space was not capable of accommodating future growth. As a result over the years, Richards, a self-described 'frustrated architect' (personal communication, April 8, 2011), submitted a number of floor plans to support proposals for building changes. These drawings illustrate Richards’ initiative and drive to create a more functional library space (Lockwood, 1966a, 1966b; Richards, 1973b; University of Auckland Library, 1966). As a result of Richards’and Beadle’s efforts a workroom for the librarians (Figure 9) was built in late 1965 (Beadle, 1965a; C. G. S. Ellis, 1965; Fine Arts Library, 1965).

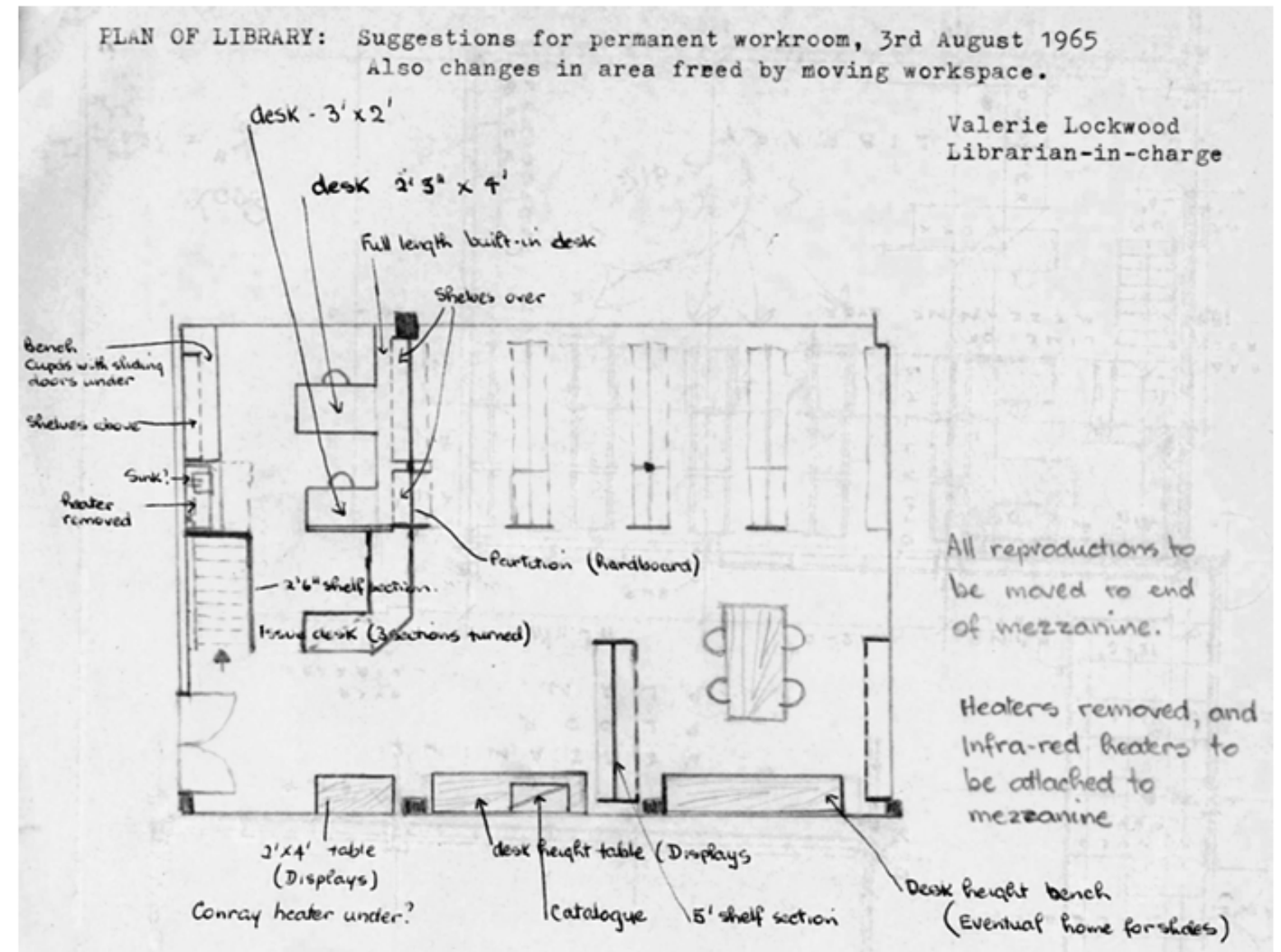

Figure 9. Suggested plan of the Library drawn by Richards (1965) 
The main floor of the AUEL housed the monographs, reading desks and filing cabinets and totalled 856.8 sq feet. A 1968 building report suggests that "the Library is perhaps the most successful interior space; sun, well considered light and working areas” (Cochran, 1968, p. 25). The image included to support this statement shows a compact and functional space (Figure 10).

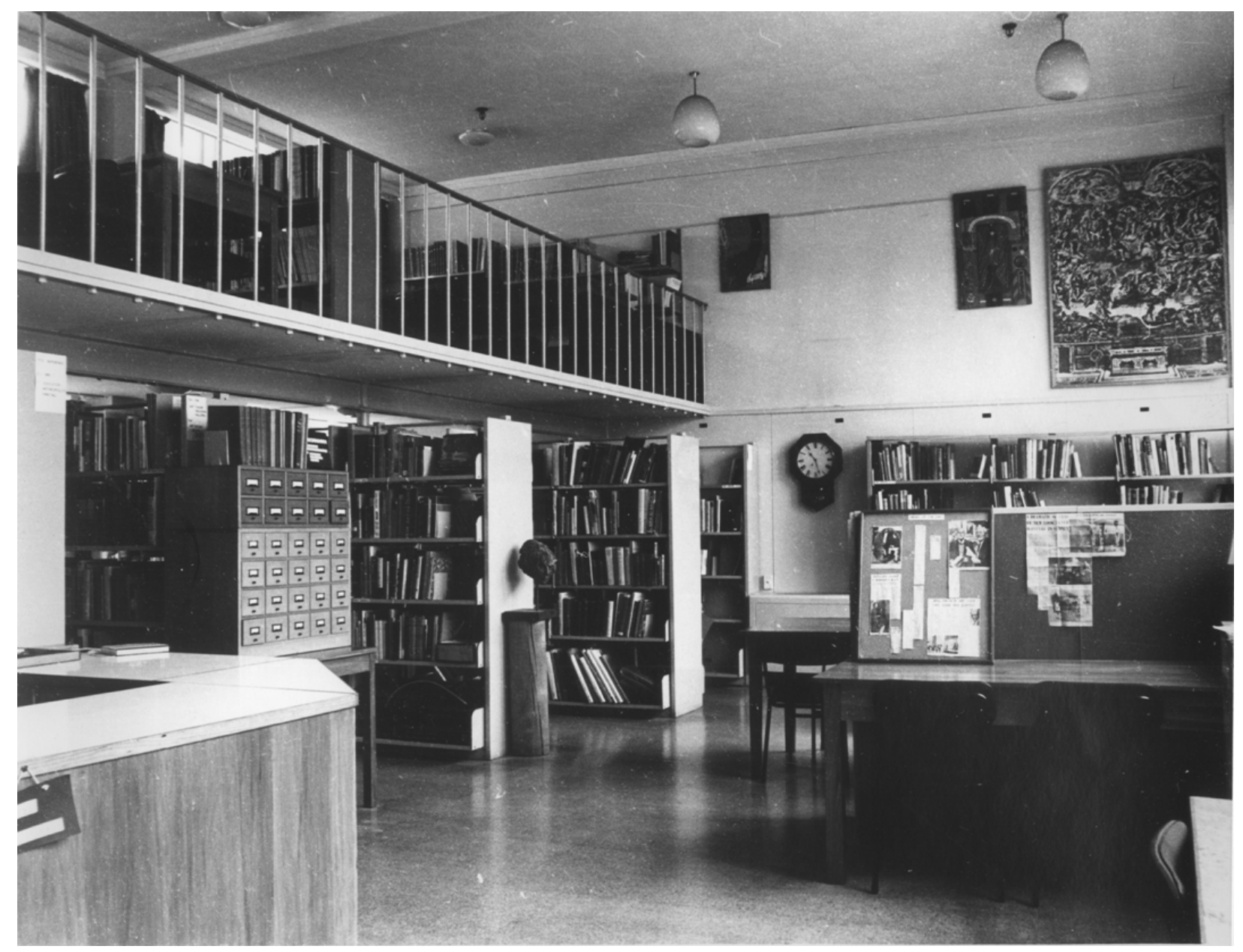

Figure 10. Fine Arts Library (1968)

Four colour interiors from 1969 also provide a valuable insight with Figures 11 and 12 showing a light filled reading area. 


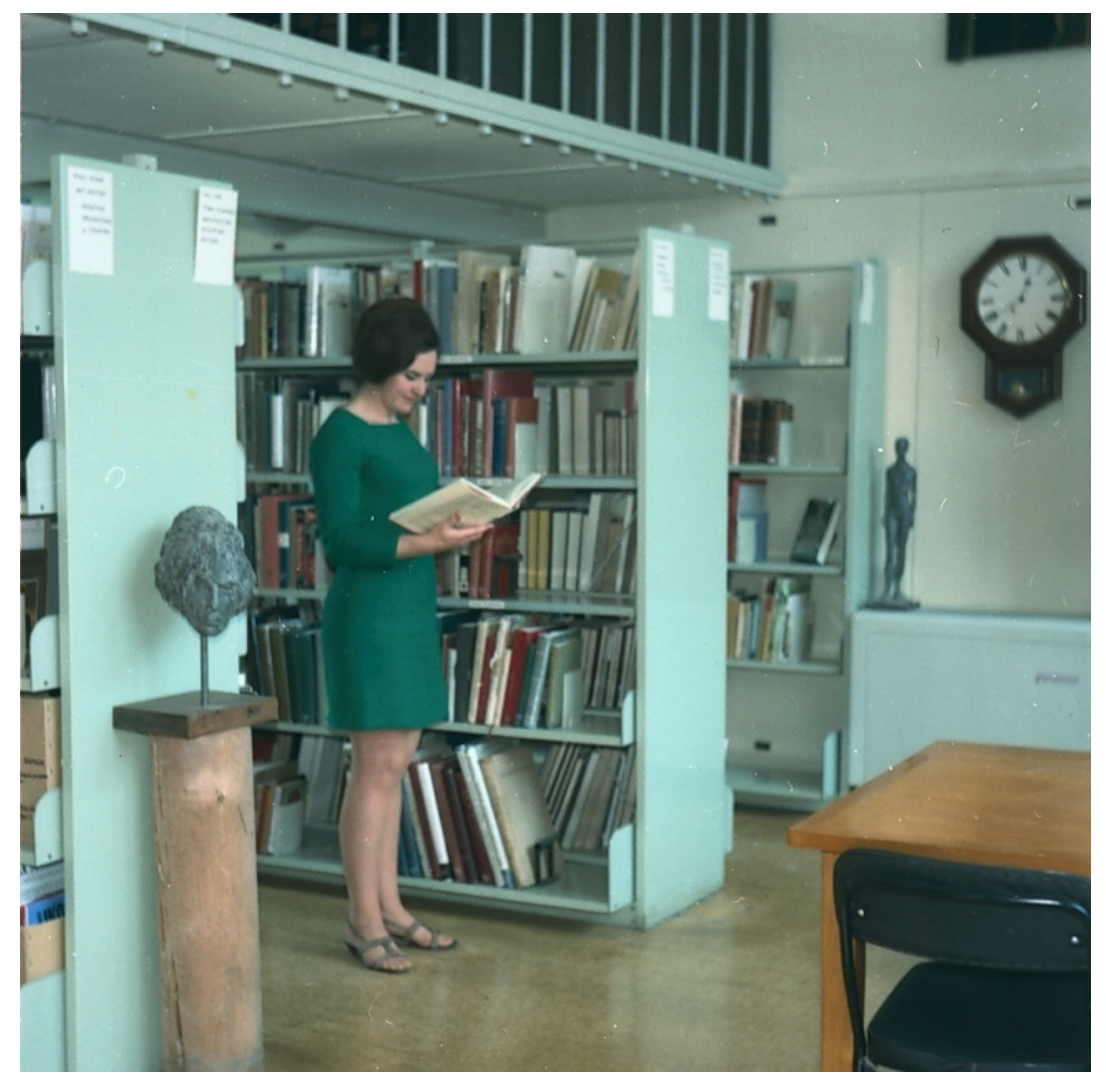

Figure 11. Richards in the Fine Arts Library (1969)

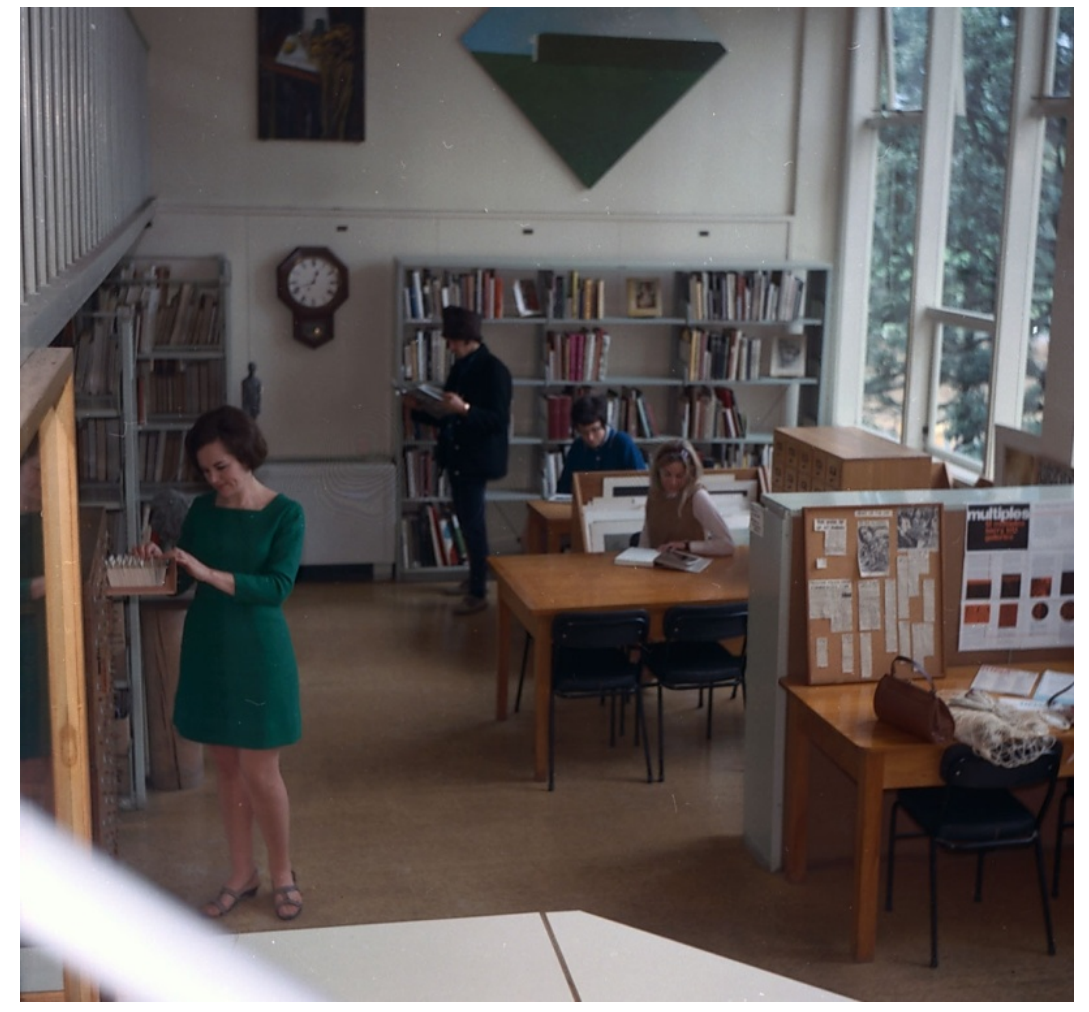

Figure 12. Richards and students in the Fine Arts Library (1969). View from the mezzanine stairs 
The average number of books and serials purchased in the 1960s and early 1970s amounted to almost 800 items per year. The shelves in the above images are not yet filled although in the same year the Library was deemed at capacity. The term 'capacity' may be in reference to the collection in the mezzanine floor of which a complete image has not been discovered.

The mezzanine floor (274 sq feet) viewed by some as “an afterthought” was initially utilised as a reading area and later for the periodical collection (Library - Elam, 1963). Figure 13 partially shows a bright, modern and comfortable reading area. Only five years later this space was to be a cramped and arguably uninviting section of the Library.

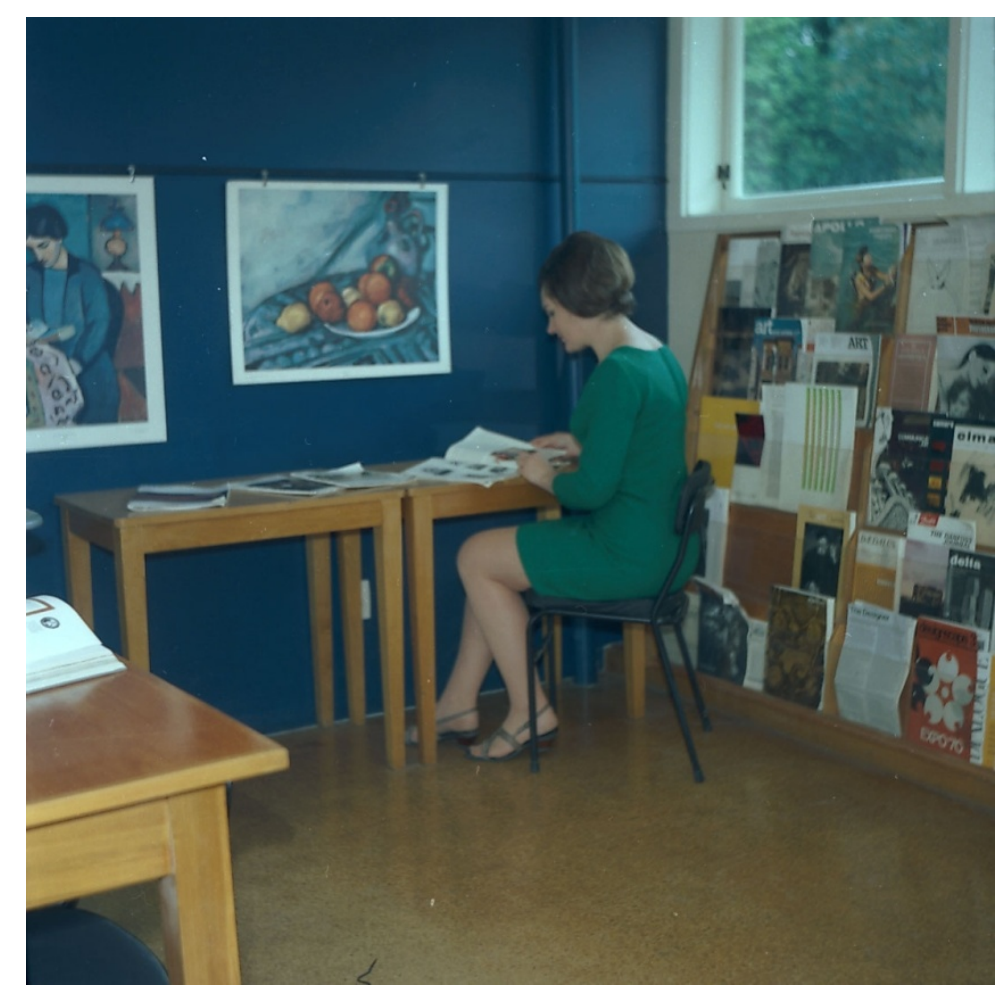

Figure 13. Richards in the mezzanine reading area facing southern wall (1969)

In response to the issue of space Richards submitted a further proposal to extend the mezzanine (Figures 14 and 15). This plan was approved and in 1970 the staircase was 
moved to the far end of the Library and the mezzanine was extended by an additional 175 square feet (Fine Arts Library, 1970, 1971; Richards, 1970a, 1983a; The University of Auckland Library, 1970).

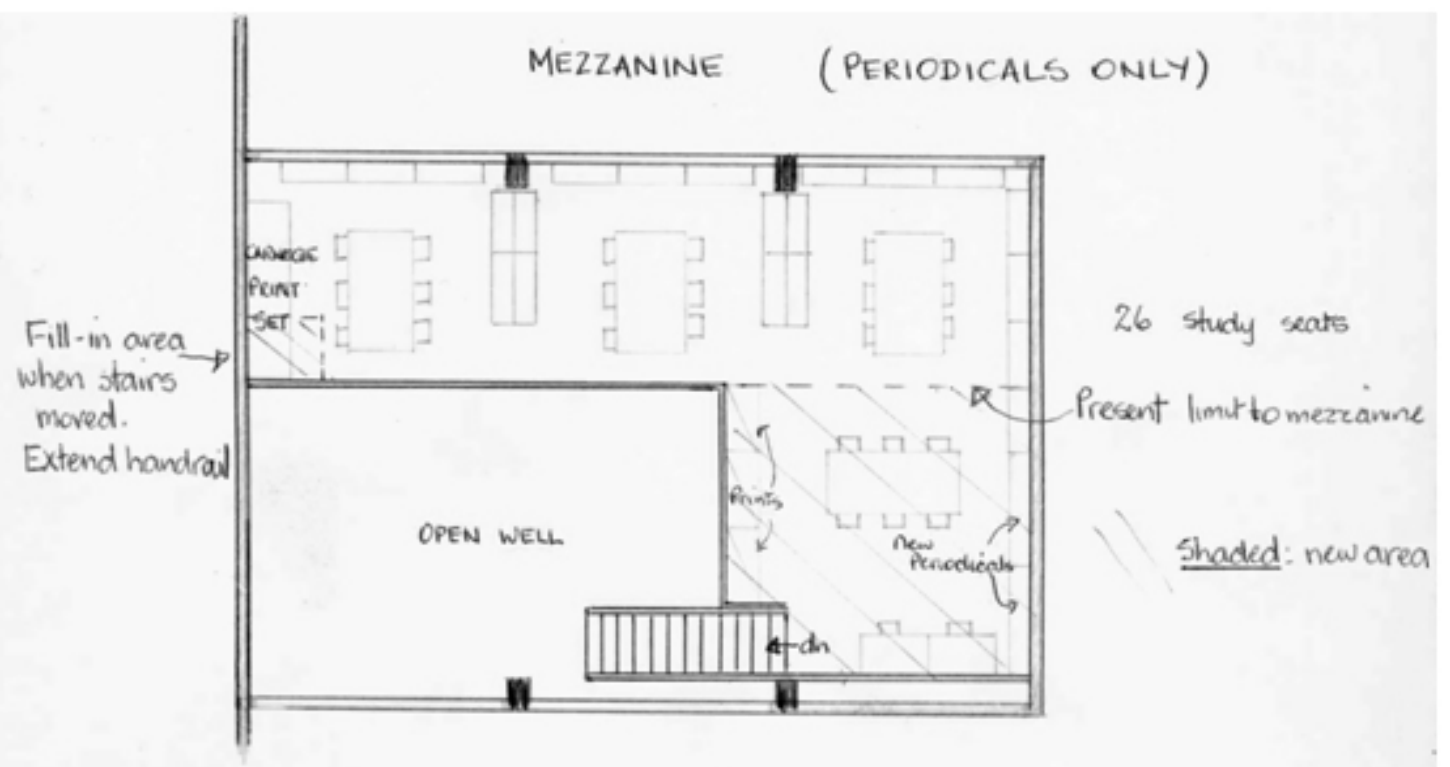

Figure 14. 1965 drawing by Richards for the proposed extensions to the Fine Arts Library (Mezzanine Floor, Periodicals Only)

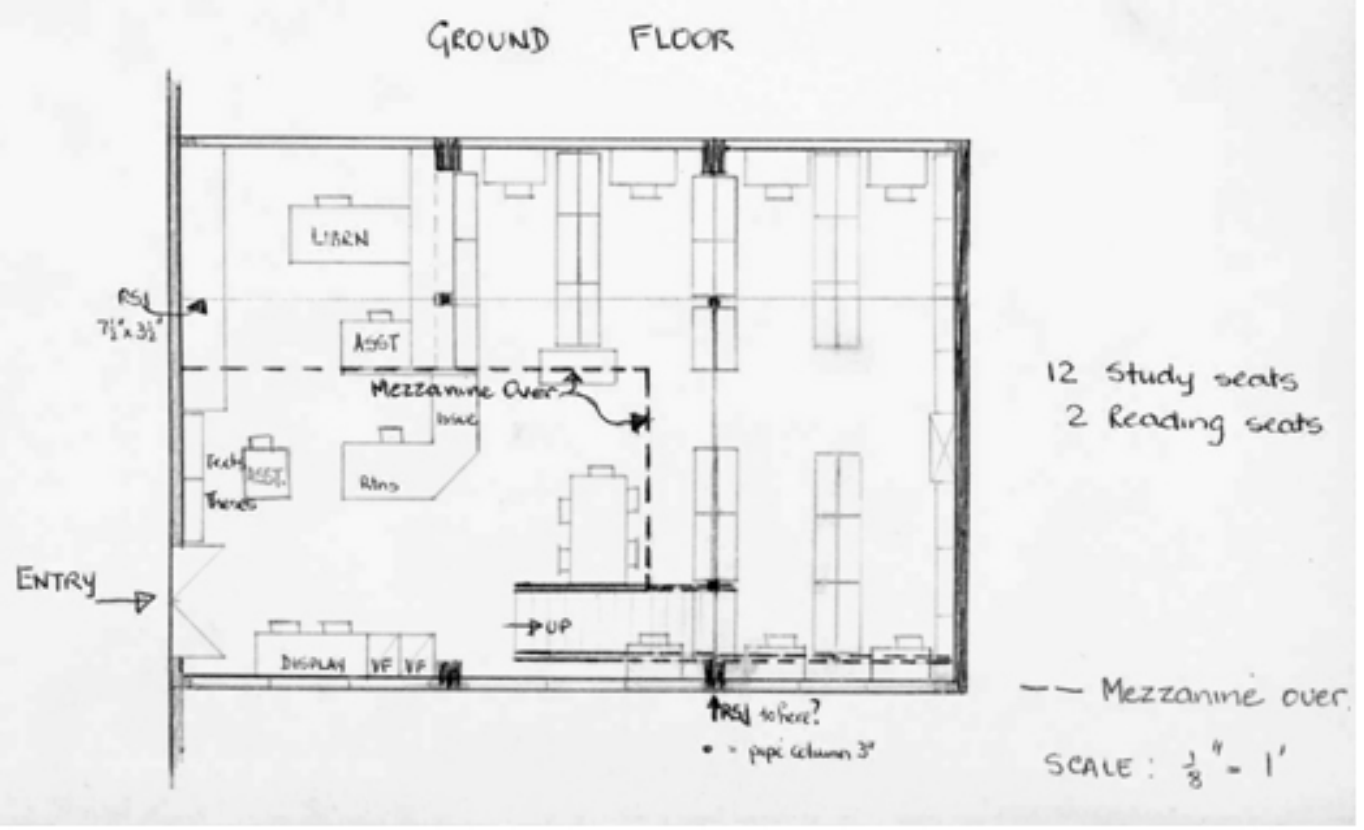

Figure 15. 1965 drawing by Richards for the proposed extensions to the Fine Arts Library (Ground Floor) 


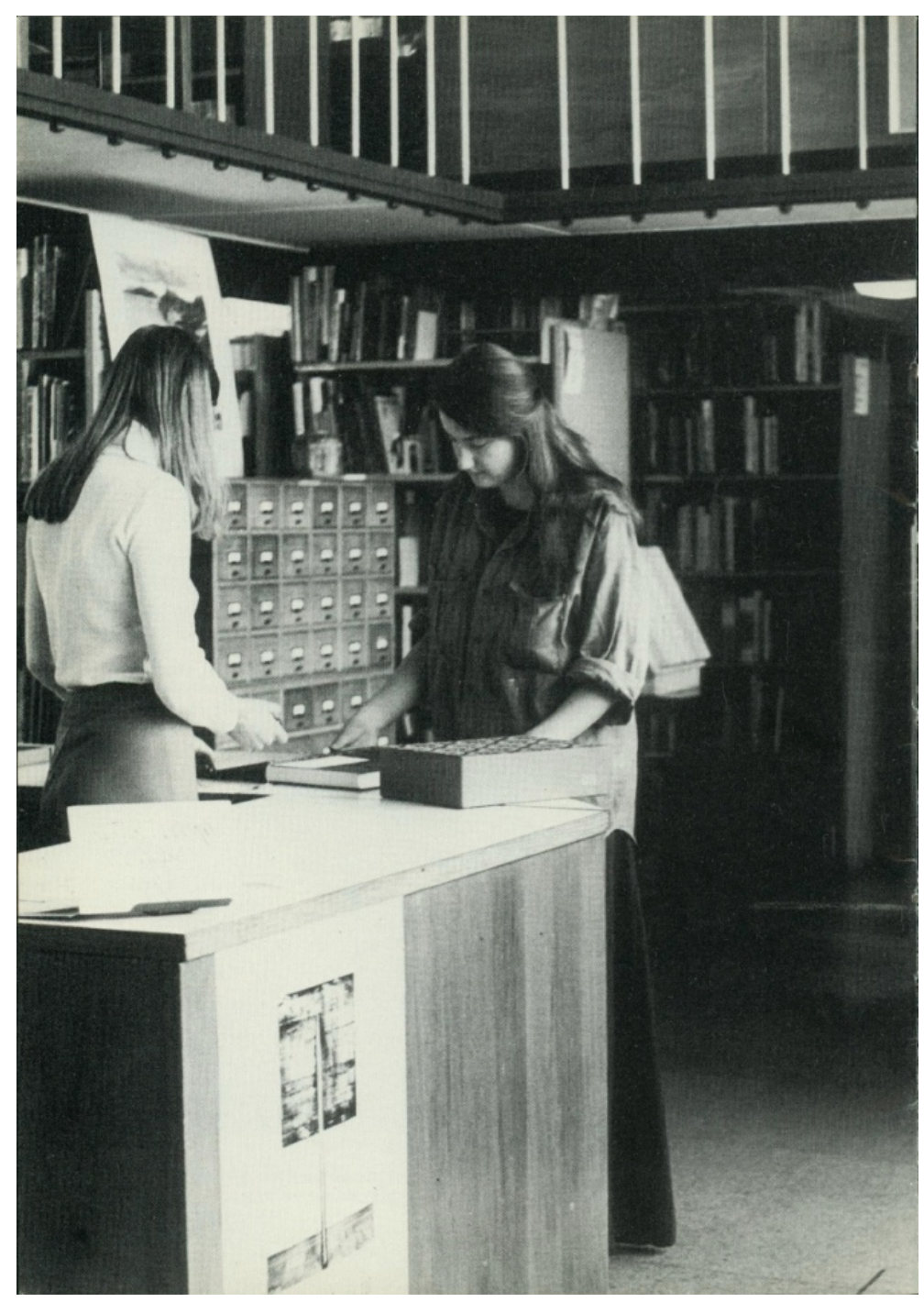

Figure 16. The Fine Arts Library in 1975. The image partially shows the front desk (mid-ground) and the extension to the mezzanine floor (top right)

While this alteration restricted movement in the main reading area (Richards, 1970b), it streamlined workflow (Figure 16). However, the change, as suggested by Durey, "exhausts the amount of space available and at the end of 1972 all available shelving will be completely full” (Durey, 1970). 


\section{Developing the Collection}

The Northern Hemisphere Art Libraries of the 1960s experienced an "immense output of books, exhibition catalogues, manifestoes, posters...slides, and similar material” (A. Davis, 1969, p. 9). Unfortunately for their Australasian counterparts, distance from major markets and a lack of funding restricted access to these resources. As discussed by Richards,

[Antipodean] Art Librarians... found themselves competing against better-funded American libraries who were weeks closer to the market. It is normal for parcels to take more than 10 weeks to arrive from either Europe or North America...booksellers lists arrive long after important titles have been sold... (1986a, p. 13)

From the mid-1960s a number of publications concerning art libraries and their administration emphasised the importance of collecting exhibition catalogues and other ephemeral art related materials (Broxis, 1968; A. Davis, 1969; Neal, 1973; Pacey, 1980b; Pollard, 1977, 1978; D. L. Smith \& Baxter, 1965; Wegner, 1980). These authors identified that this material was as an important source of visual and textual information. They also acknowledged that they were hard to source and difficult to catalogue.

The AUEL was also constrained by the lack of substantial New Zealand art related publications in book or catalogue format. There were some exceptions including the seminal publication by the AUEL's first Librarian-in-charge Gordon H. Brown (1969). A standing order had been created for all catalogues published by the Auckland City Arts Gallery, The National Gallery and the Hocken Library (Elam School of Fine Arts, 1966). However, these publications were written by and created for public art galleries whose generally conservative and traditional exhibition programmes focused on American and 
Eurocentric artists and themes. In response to this situation the Library established a collection of New Zealand art ephemera. This included exhibition posters, invitations, and exhibition catalogues which were largely un-catalogued (Richards, 1981) and housed in “geographically arranged boxes” (Fine Arts Librarian, 1979, p. 2). The creation of this collection supports the notion put forward by Pacey, that an art library should be biased towards its own locale (1980c). This collection provided a valuable resource for students and staff interested in New Zealand related art theory and practice (Coleman, 1973; University of Auckland, 1974).

The paucity of New Zealand's art resources also made it a necessity for the Library to manage and produce a press cutting index, “clippings will be kept in scrap-books for future reference” (Fine Arts Library \& Richards, 1965, p. 1). From 1965, the Library, with the financial support of Elam and later Art History, subscribed to a press cuttings service. The press cuttings were housed in vertical file cabinets alongside the art related ephemera (Figure 17)

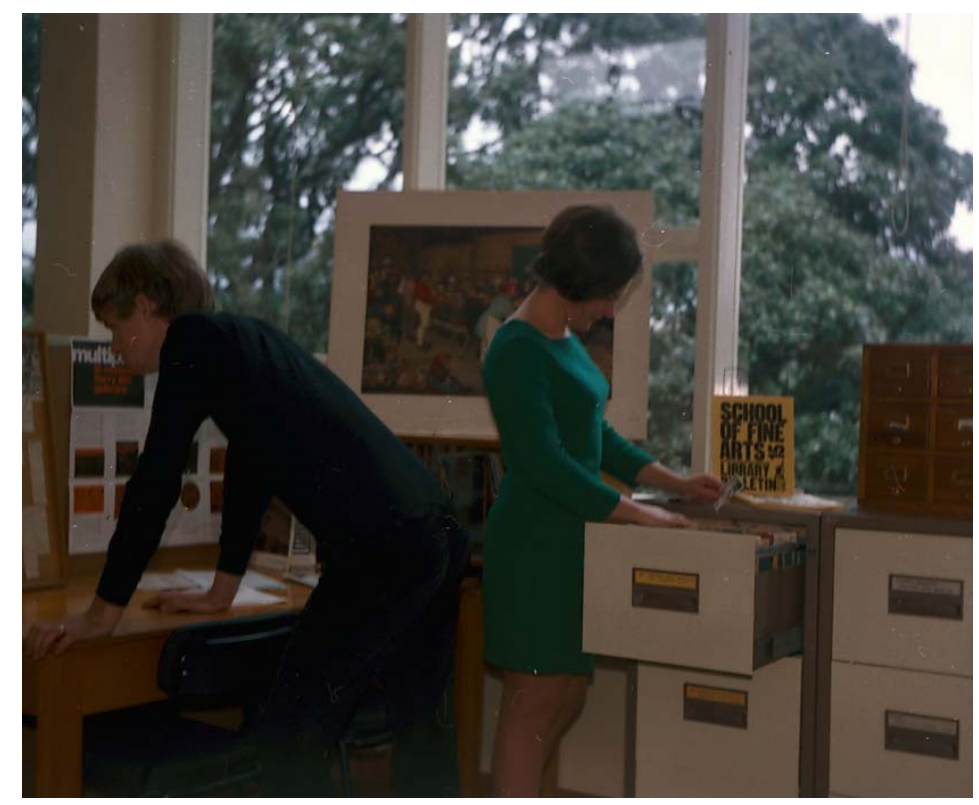

Figure 17: Richards looking through ephemera files while a library patron looks at press cuttings display (1969) 
New Zealand art journals were also indexed and filed separately. In 1970 the AUEL was described by Richards “as the most comprehensive of its subject in New Zealand” (Richards, 1970b). This was in part due to the creation of these reference collections.

The AUEL also purchased a number of international bibliographic resources (Fine Arts Library, 1976). Publications such as ARTbibliographies Modern (Walker, 1971), the Art Index and Repertoire International de l'Art (RILA), first published in the late 1960s, focused on the contemporary art of Britain, Europe and America ("Art bibliographies," 1972). These were valuable resources when identifying international trends. However, they may have prejudiced the user into believing that New Zealand art practice was invisible or undervalued. This lack of information in regard to the New Zealand 'art scene' was another one of the motivating factors behind the creation of the AUEL's unique reference collections.

First instituted in 1950 the budget for the AU and all New Zealand Universities were provided in set allotments (New Zealand. Committee on New Zealand Universities \& Parry, 1960; Sinclair, 1983; The University of Auckland Library, 1970). Staff had to provide budgets for a five year period (quinquennium). This created significant financial strain, as the effects of devaluation and the exchange rate meant that while staffing needs and student demands increased, the budget could remain at the same level of the previous year or two years. This situation was combined with the ever "alarming rise in prices of books and periodicals” (The University of Auckland Library, 1971, p. 1). From the 1960s and into the mid-1970s the AUEL collection development and cataloguing would be best described as being based on constraint and compromise (V. Richards, personal communication, April 8, 2011). 
The AUEL’s annual grant increased from \$3,350 in 1970 to \$5,525 in 1971 (Fine Arts Library, 1972, 1973; The University of Auckland Library, 1972). Despite this in 1972 the purchasing power per Art Historical item was almost half that of other departments (Department of Art History \& Green, 1972). The Library's purchases were restricted to curricular specific items and the financial constraints did not "provide for exploration beyond the confines of the syllabus” (Pacey, 1980c, p. 13).

The low staffing levels and the on average annual 4\% increase in library use between 1970 and 1975 also added to the challenges. An additional part-time Library Assistant was appointed in 1970 (Fine Arts Library, 1970) followed by a second full-time Library Assistant in 1973. However, library use always outstripped staffing resources (V. Richards, personal communication, April 8, 2011).

In this restrained financial context the Library was the grateful recipient of a number of donations, gifts, and exchanged items. These came from former and current staff and students, the Elam Trust, art galleries and museums and a number of other philanthropic organisations and individuals (Fine Arts Library, 1974; McCahon, 1976; Richards, 1969, 1974). Donations from Fletcher Industries, one of the most significant corporate patrons, allowed the Library to purchase items that they would otherwise not have been able to afford (Figure 18) 


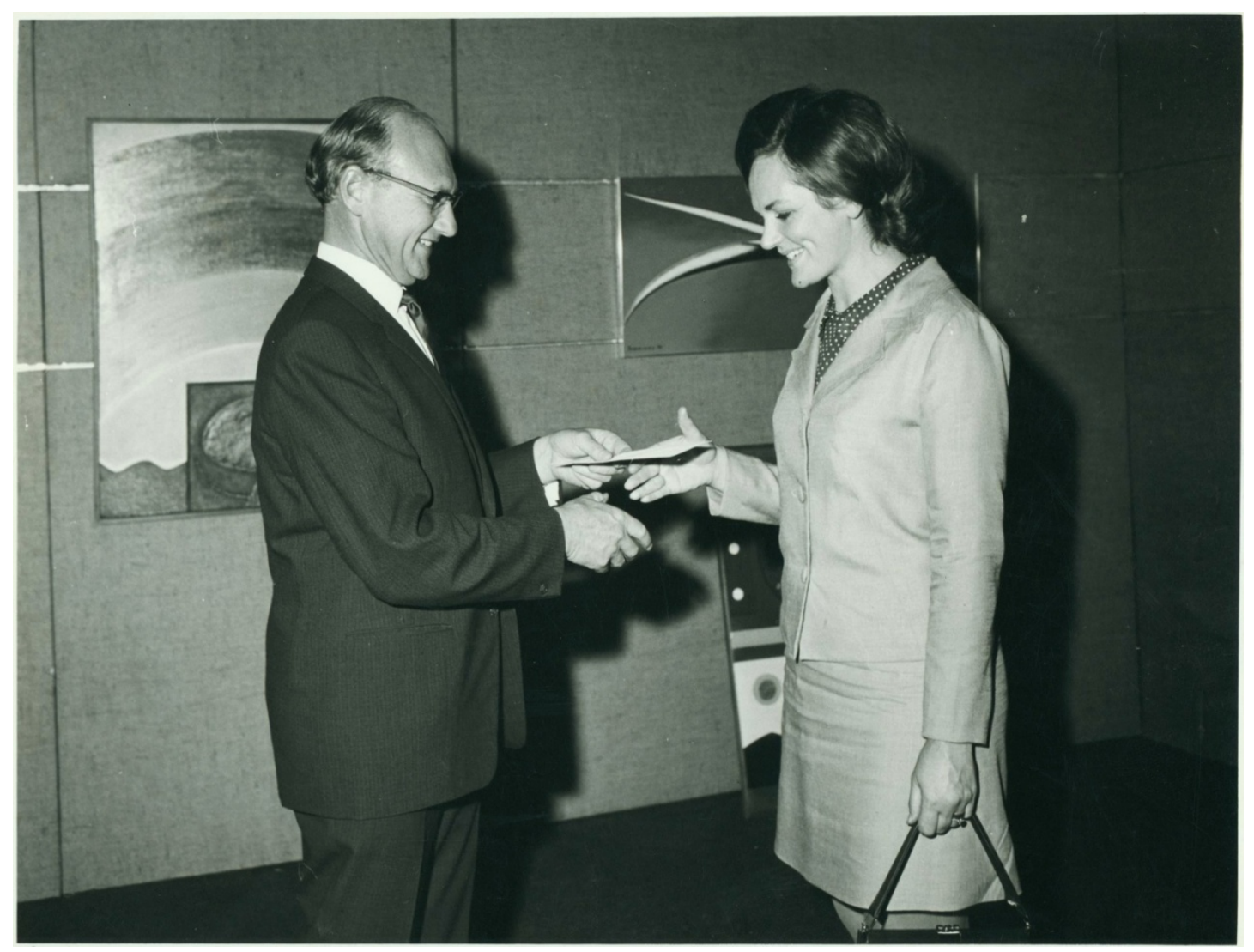

Figure 18. Valerie Richards (Fine Arts Librarian) receiving a \$100 cheque from a Fletcher Industries representative in c.1968

The Library was also involved in exchange networks with art libraries and related cultural institutions. The purpose of the Fine Arts Library Bulletin (1965-1990), created and written by Richards, was both promotional and informational. It was sent to and, exchanged with, other libraries and interested parties both domestically and internationally (D. L. Smith \& Baxter, 1965). The Bulletin also created a connection between the Library and Elam by providing an opportunity to showcase the work of an Elam staff member or student, commissioned to design the cover page. Figure 19 created by Richard Wolfe is an example of this collaboration (Richards, 1972b; Wolfe, 1972a). 


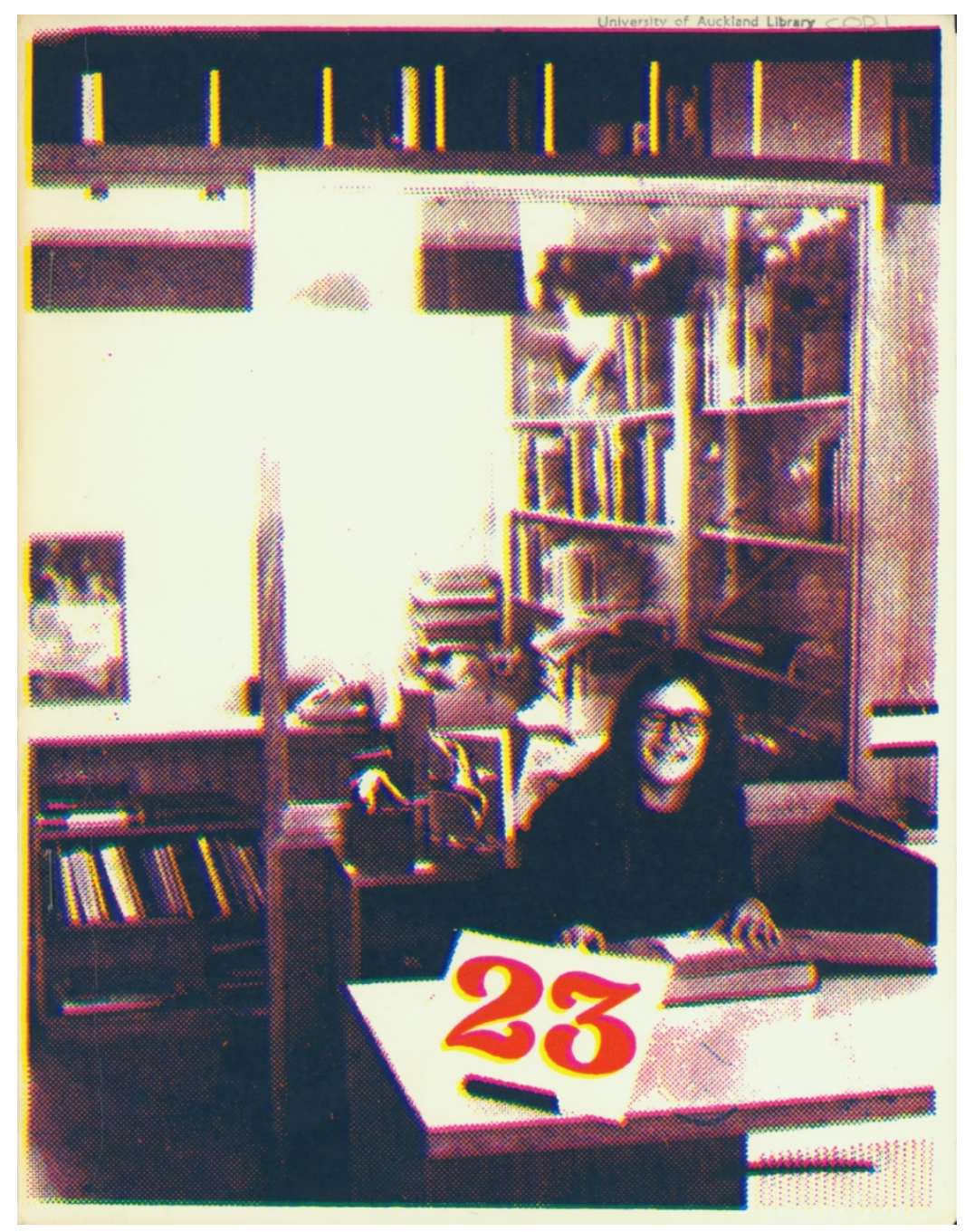

Figure 19. 1972 cover of Fine Arts Library Bulletin (v.23) by Richard Wolfe. Jane Shallcrass, Library Assistant, sits at issuing desk

Elam’s lack of permanent exhibition space (Cochran, 1968; Richards, 1983a; Twiss, 1973) saw the Library taking on this role, furthering connections between the Library and the School. The Library maintained a well-supported exhibition calendar of staff and student work throughout Richards’ tenure (Fine Arts Library \& Richards, 1968, 1977). 
Student propelled projects included the Open Drawer and the Post-Object Art Files (Elam

School of Fine Arts, c.1970-1989; Passau \& Fine Arts Library, 2010b). The former project, consisting of a "living archive" of mail art, was managed by the AUEL (Fig 20) ("Inch Art," 1976).

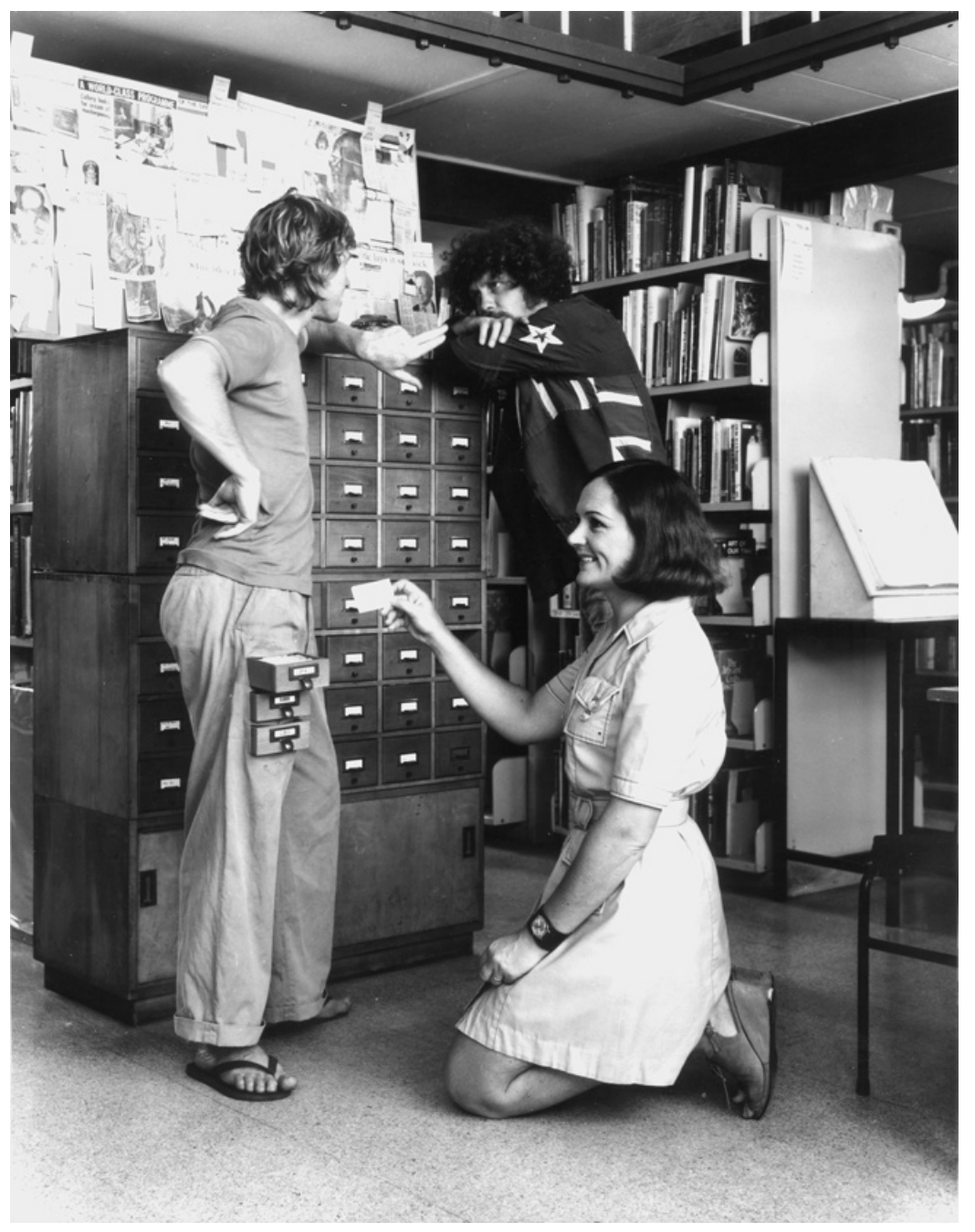

Figure 20. Richards (kneeling) with two of the creator creators of the Open Drawers archive Phil Dadson (left) and Terry Reid (far right) 
During this period the students felt an increased sense of ownership of Elam (Baloghy, 1976; Franks, 1984) and the Library. This was also emphasised by the number of Elam students employed as part-time desk assistants. This employment ethos has had a number of advantages. These have included the injection of fresh perspectives, significant subject knowledge and have enabled staff to cultivate more informal relationship between the students and Library staff.

\section{Art History and Teaching}

The creation of Art History as a separate Department within the Faculty of Arts in 1967 changed the relationship the Department had with both the School and the Library. The establishment of this department meant that the AUEL now officially serviced both Elam and Art History and was the only tertiary library to do so in New Zealand (Richards, 1983a).

In this same year the Bachelor of Fine Arts Degree was introduced. "This course now had a greater emphasis on academic study, with two papers in Art History being prescribed in Stage One, and three [sic] Art History papers at Stages Two and Three” (Franks, 1984, p. 56).

In 1969 Art History was moved to 21 Symonds Street (Fine Arts Library, 1970). Access to the Library by the Art History staff and students has been an issue ever since. To assuage her concern that Art History students would no longer patronise the Library, Richards “persuaded” (personal communication, April 8, 2011) Art History to include Library tours for first year Art History students (Lockwood, 1967). In the first two weeks of each term Library staff carried out approximately 20 tours, described as follows: 
I added in ... research things like saying, because nobody else seemed to, "Remember you are doing your art history by reproduction in a book, think about size, think about colour because print colour is not paint colour” ...we gradually developed a routine...”(V. Richards, personal communication, April 8, 2011).

Richards' provision of library tours was a positive advance (Neal, 1973).

From 1962 onwards, the Library began to purchase $35 \mathrm{~mm}$ slides, to support this new focus on art history, (Craccum Reporter, 1963; Fine Arts Library Sub-Committee, 1960; von Meier, c.1963). While this image resource was later transferred to Art History (Green, 1975b; Saunders, 1975), The AUEL continued to collect photographs, colour plates, postcards and other visual resources (Murray, 1975; Pacey, 1982).

\section{Communication}

Peter Durey, appointed as the University Librarian in 1970, brought a fresh approach to the Library. He wanted to ensure that the Library was viewed "an integral part of the intellectual life of the institution” (Johnson, 1988, p. 15). Richards commented that Durey was very supportive in getting the Fine Arts Librarian elected onto the Faculty of Fine Arts (Elam School of Fine Arts, 1970).

...Peter had the good sense to see that the Subject Librarians were part of faculties...and that helped enormously because Art History was a member on the Fine Arts Faculty...so you knew what was being planned... that was very useful and...made you a greater part of the whole School complex. (V. Richards, personal communication, April 8, 2011) 
The relationship between Elam and Art History was also cemented through other lines of communication with each Head consulted in regards to the yearly submission for the Library budget. The Fine Arts Library Committee also provided an opportunity for Elam and Art History to assess and comment on the progress and direction of the Library’s collection (R. Ellis, 1969). However, in terms of providing suggestions for purchase Richards "was not so sure that the art historians were $100 \%$ helpful in that direction...maybe they had confidence that I'd turn up with things that... they'd want for their course work or were of interest to them” (personal communication, April 8, 2011). This attitude, which was also arguably held by the Elam staff, supports the theory that libraries are perceived as holding the "buyer” function (Schonfeld \& Housewright, 2010). "Even though academic departments are supposed to be responsible for making their own recommendations for the library, we rely on librarians to show us what's out there” (Jenkins, 2005, p. 115). This generally hands-off approach did not limit the Departments from providing feedback regarding new acquisitions. Anthony Green, Head of the Department of Art History, wrote in a letter to Richards,

You and I have worked very happily on library matters for the past five years. I hope that what I am going to say will not disrupt that.

I saw a book on 18th Century Painting by Clare [sic] Gay. I hope you do not mind me saying that I would be very glad if you would discuss books of this sort with me since they are in my specialist field. I don’t think this is a very good one (Green, 1975a). 
Interestingly this book (Gay, 1968) is still available for loan. This confirms that, while academics were free to provide feedback, the Library made its own decisions in regards to acquisition and collection development.

\section{Academic and Student Disputes}

In the 1970s students were unhappy with the running of the School and the curriculum ("Elam stirs: students expresss disatisfaction," 1972; Wolfe, 1972b). The Art History papers were seen to be irrelevant to the Bachelor of Fine Arts students. The increasing number of disputes resulted in an academic review in 1973 (Franks, 1984; The University of Auckland, 1973).

The Art History curriculum was partly restricted by the resources available at the AUEL. The Department felt constrained to focus on artists who were well represented in the Library’s collection (McLaren, 1972). In addition, the Art History curriculum ignored the needs and interests of Elam students who wanted to engage with and learn about developments in contemporary art practice both internationally and within New Zealand (Wolfe, 1972b). The Library, recognising the need to develop a more comprehensive collection, not only purchased books on historic artists and conservative art theory but acquired items on a range of topics and a number of "avant-garde” publications as finances allowed (Richards, 1983a).

By providing a spectrum of resources the Library acknowledged the different needs of their users (V. Richards, personal communication, April 8, 2011). Art history students needed theoretical and text based resources to complete essays and written assignments. In contrast, Elam's practical studio assignments meant that fine art students required a diverse 
range of books and journals that would visually and conceptually 'inspire' them to create art (Fawcett, 1975; Pacey, 1982; Toyne, 1977; Varley, 1977).

The Elam students' public dissatisfaction played a strong part in the introduction of a New Zealand Art History paper in 1974, the first of its kind taught at an undergraduate level ("News from departments," 1975). The changes to the curriculum saw an increase in reference queries and library use. During 1975 the Library developed 'bibliographic tools' or lists of books and articles relevant to a certain topic (Fine Arts Library, 1975). However, the Library did not expand its traditional tours to include in-depth bibliographic instruction (Toyne, 1977) or participate “in education at studio level” (Slythe, 1973, p. 75). Philip Pacey, Chairman of Art Libraries Society / United Kingdom who visited Australian and New Zealand art libraries in 1979 noted:

I sensed that, in libraries serving art education, the training of students in the use of the library and of information sources, is emphasised less than it might be, although I am the first to recognise the natural limitations which constrain this kind of activity not least where art students are concerned. (Pacey, 1980a, p. 3)

Hardesty (1995) described the period after 1969 as the "modern period of bibliographic instruction” (p. 339), with Kennedy (1970) a leader of this field. A major theme identified was that library instruction was not supported by faculty. Richards' remembrances suggest that while there was a core group of academic staff who supported the Library, the departments on the whole did not on consider that providing library instruction was integral to the education of their students (personal communication, April 8, 2011). 


\section{Culture}

Richards, a very determined individual with a forthright personality, can be identified as the 'founder' of the Library’s culture (Schein, 1991, 2010). The Library had a hierarchical organisational structure, appropriate for an environment that was experiencing "relatively little change in work requirements” (Line, 1991, p. 99). “I think the students thought of me as 'Dragon Lady'...Because I said what I thought... But I did to the staff too” (V. Richards, personal communication, April 8, 2011).

Throughout the history of the AUEL there has been a tendency for the Library to view itself as an independent outpost. Johnson argued that by 1979 "the individual destinies of the Divisional Libraries” ran in parallel to the AU (Johnson, 1988). The ‘can-do attitude’ and autonomous approach to managing the library was created out of necessity and is not unlike experiences of other organisations (Varley, 1977). The Art Library Society went so far as to argue that a "properly functioning art library must have a degree of administrative autonomy” (1974, p. 8) from both the department they service and the main library. When asked whether she encountered any problems introducing project proposals, Richards replied, "I found it best to do things and ask afterwards, well never ask actually. If people noticed I’ll say “Ohh, yes”...You'll find that the Special School Librarians were a bit of a rule unto themselves” (V. Richards, personal communication, April 8, 2011). This response was not unusual within the special libraries community (G. Smith, 1975).

The Library, while situated within the School's environs and part of Elam activities, maintained its own identity and did not align itself to Elam’s self-defined culture as a rebellious outsider in an inflexible tertiary environment (Macpherson, 1999a, 1999b). 
Richards made a concerted effort to involve the AUEL and its staff in a number of initiatives both within the AU system ("AULSA Committee 1975/76," 1976, June; "Officers for 1977," 1977, July; Richards, 1973a, 1975a, 1975b, 1975d; "Who are your delegates?," 1974) and in the wider arts community including the development of the New Zealand branch of Art Libraries Society /Australia New Zealand in 1976 (Fine Arts Library, 1983; Richards, 1982, 1986a).

\section{Library Use}

The early to mid-1970s saw a natural increase in Library use, creating a need for additional staff. Unfortunately the creation of these positions was constantly postponed due to financial and accommodation factors. As Richards noted, by August 1972 sketch plans for a new library had been completed and were due to be sent to the University Grants Committee for final approval. "In the meantime accommodation has become acute and shows signs of less use than would be expected of 600 borrowers in a more spacious area" (1972a, p. 3).

The restricted space had a significant effect on book issues and student access, reflected in the low Library use of undergraduate Art History students (Fine Arts Library, 1975, 1976; Richards, 1976). In these years Library staff resorted to requesting students to take home “barrow loads of books” (Richards, 1975c) over the summer period to ease the accommodation issues (Fine Arts Librarian, 1976, 1979). By 1975 the Library consisted of approximately 16,000 books, 3200 serials, 30 study desks and three staff. 
The AUEL Extension

In the early 1970s a request for an extension to the library was submitted to the University of Auckland Building Committee (The University of Auckland Library, 1972, 1974). The need for a larger library space was due to the natural growth of the collection and the “rapid” growth in Art History (Durey, 1976a). The extension (Figure 21), again designed by Beatson, Rix-Trott, Carter \& Co. in 1972, covered 5,600 square feet and cost a total of \$148,000 (Beatson Rix-Trott Carter \& Co., 1972; Fine Arts Librarian, 1977).

The Library administration acknowledged the AUEL's physical restrictions at this time (Durey, 1970; The University of Auckland Library, 1975), however it was not until 1975 that the building contract was signed.

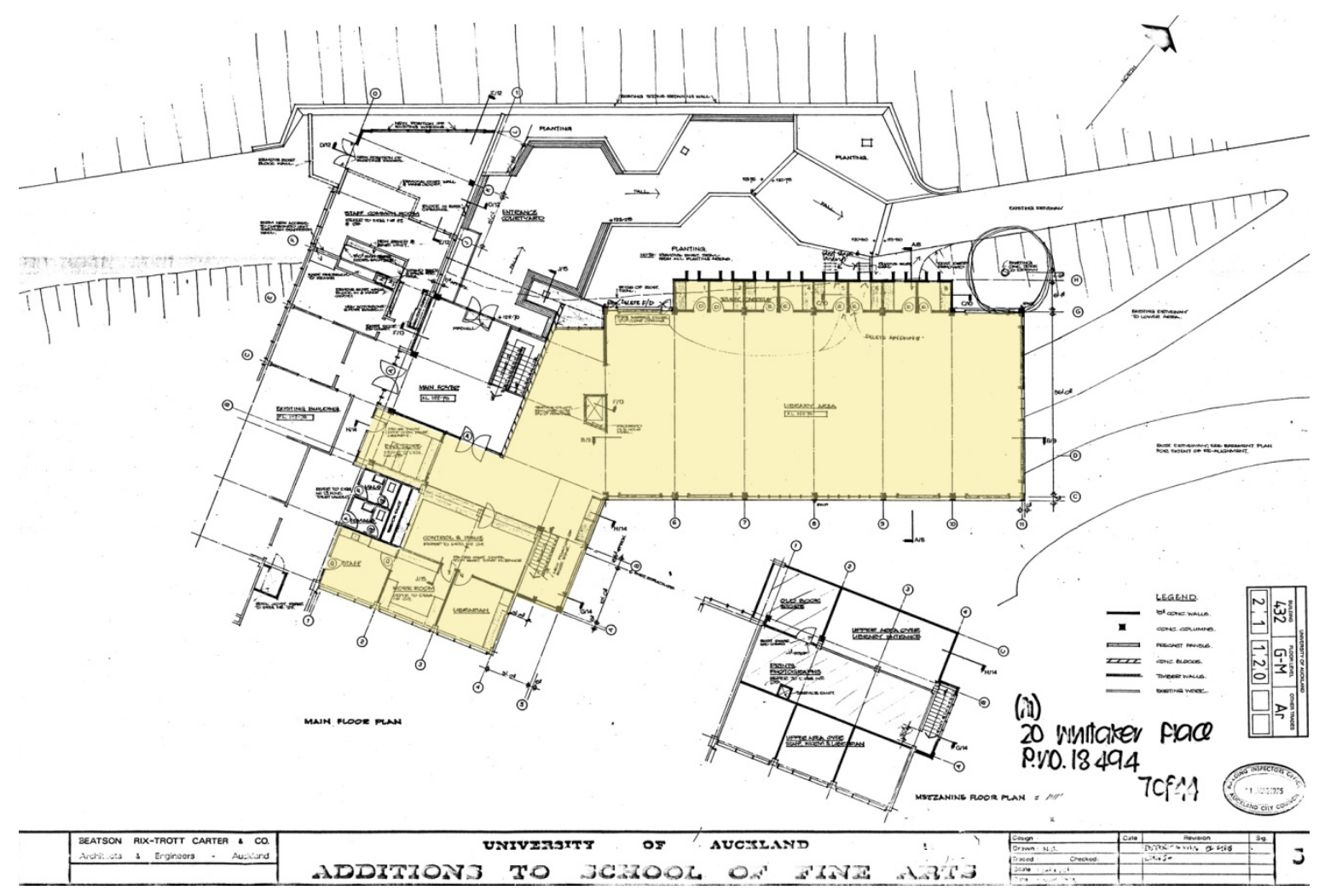

Figure 21. A plan for the additions to the School of Fine Arts, the Fine Arts Library is highlighted in yellow 
Unlike the Library's first incarnation on site, and as recommended in contemporary library literature, the project's stakeholders comprising Elam staff, the Fine Arts Librarian and the University Librarian, were involved in the design of the building (Langmead \& Beckman, 1970). The AUEL Extension Committee enabled a clear line of communication between architects and stakeholders with Richards making sure that a future increase in Library staff could be accommodated (V. Richards, personal communication, April 8, 2011). 
Chapter Three: 1976-1990

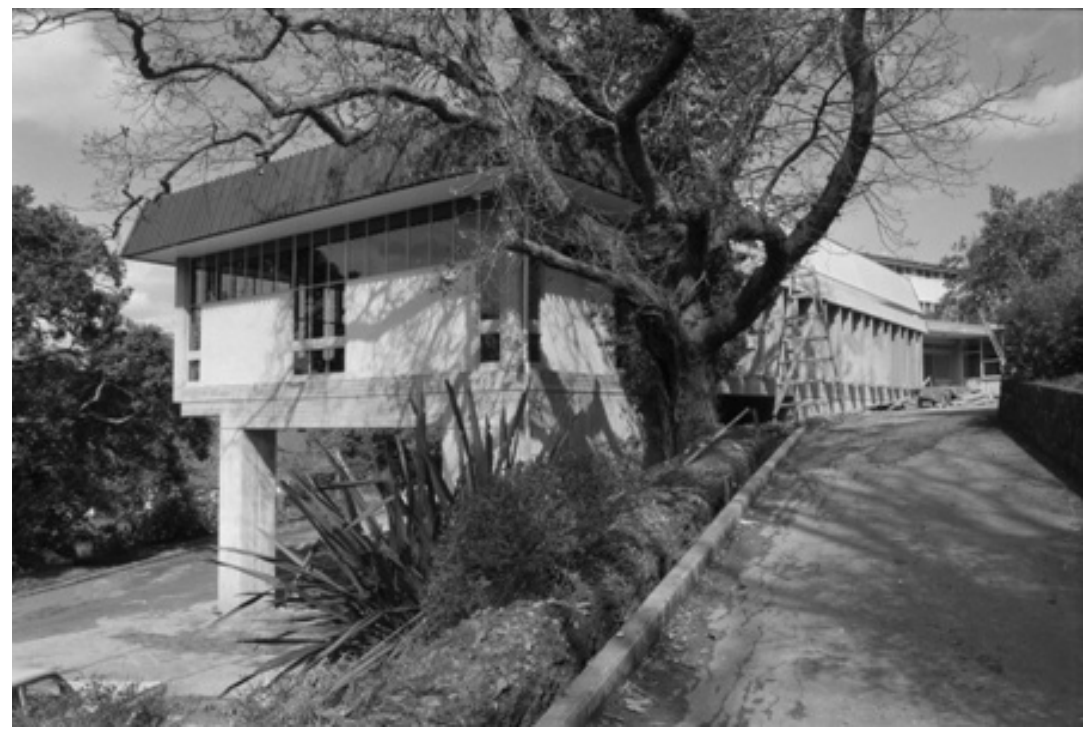

Figure 22. The Fine Arts Library Extension (1976)

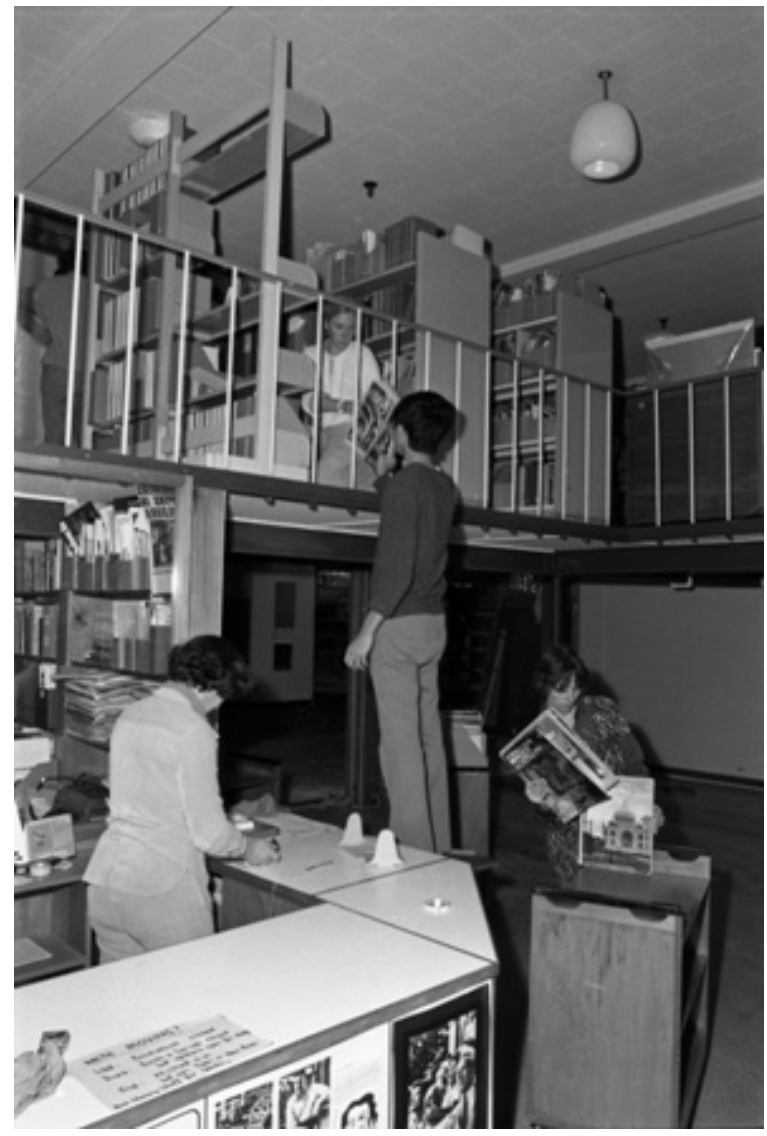

Figure 23. Moving the collection out of the ground and mezzanine floors of the original library (1976) 


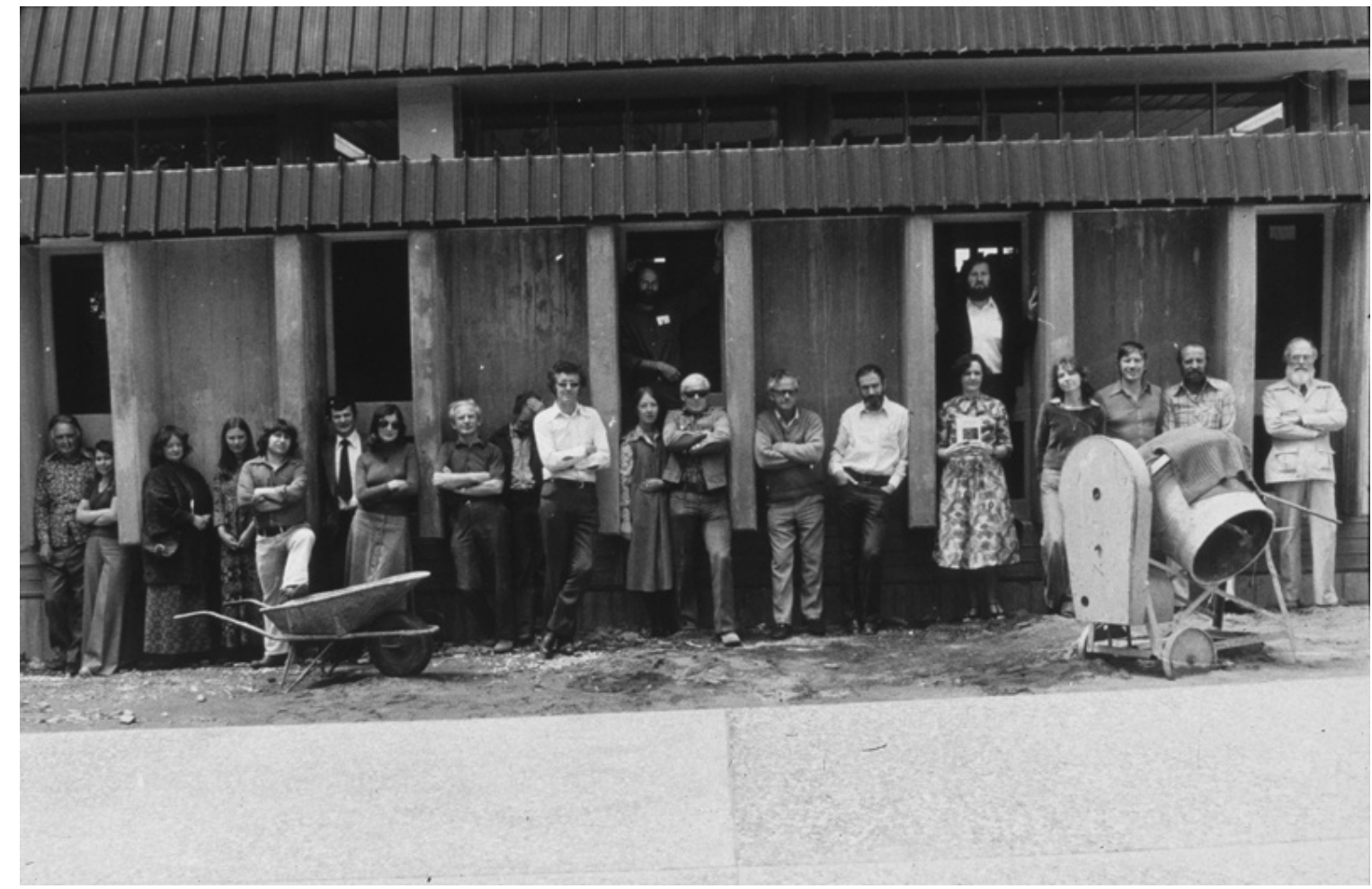

Figure 24. A photograph of Elam and Library staff was taken outside of the new building in 1976. Note Richards sixth from the right holding the text What is art all about? (Desiderius, 1975)

In the final semester of 1976 the collection was moved into the new Library (Figures 22 and 23) (Durey, 1976b) with photographs of Elam and Library staff taken to commemorate the occasion (Figure 24). The extension, officially opened by the Vice Chancellor Dr. C.J. Maiden in February 1977, was a vast improvement on the previous accommodation (Durey, 1976b, 1977; Elam School of Fine Arts, 1976). See Figures 25, 26, and 27. The collection was housed as follows:

The main stack area houses the books (classed by Dewey), monographs (A to Z of artists) and serials (A to Z by title). Non book materials and the special collections are housed on the mezzanine floor. There are seats for 85 readers and 8 individual study carrels, some of which can be used to work with AV material and equipment. Reader services available include Desk Copies (for use in the Library and overnight 
loan); Reservations; Inter-library-loan; and copying facilities. (Elam School of Fine Arts, 1976, p. 38)

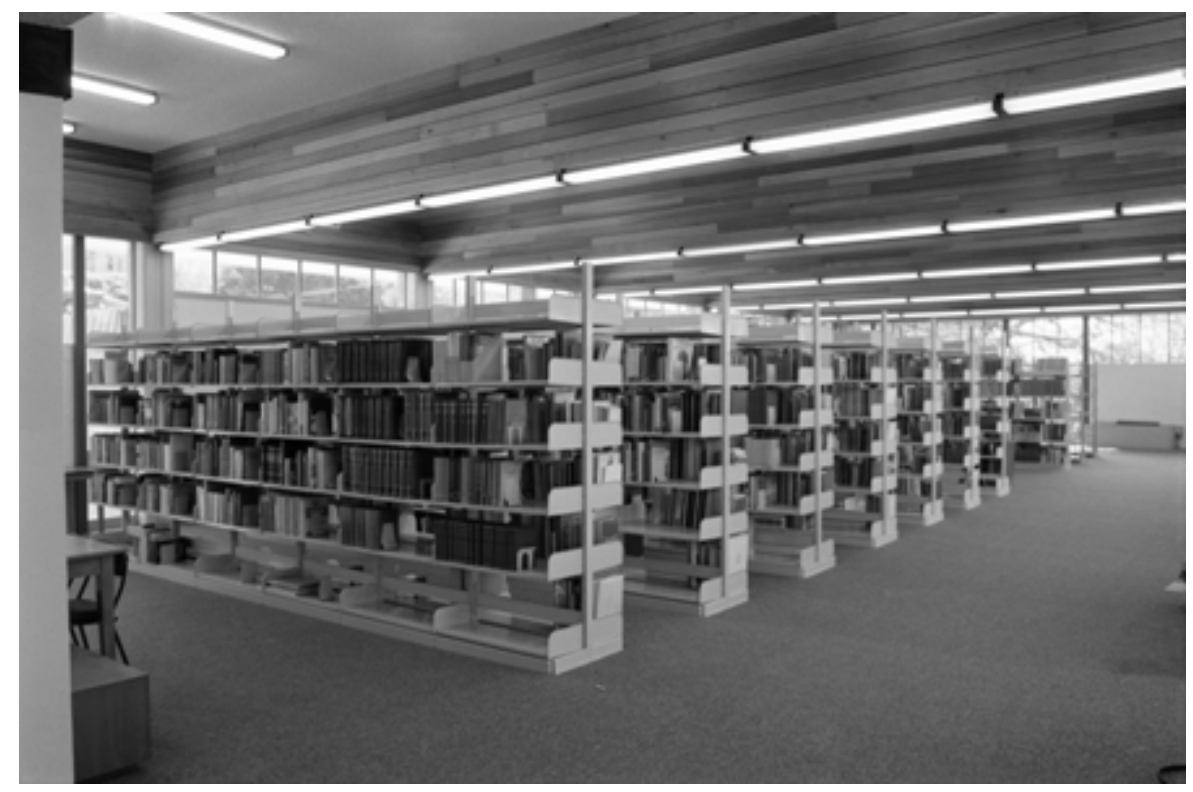

Figure 25. Interior view of the Fine Arts Library extension in 1976 looking down the Library

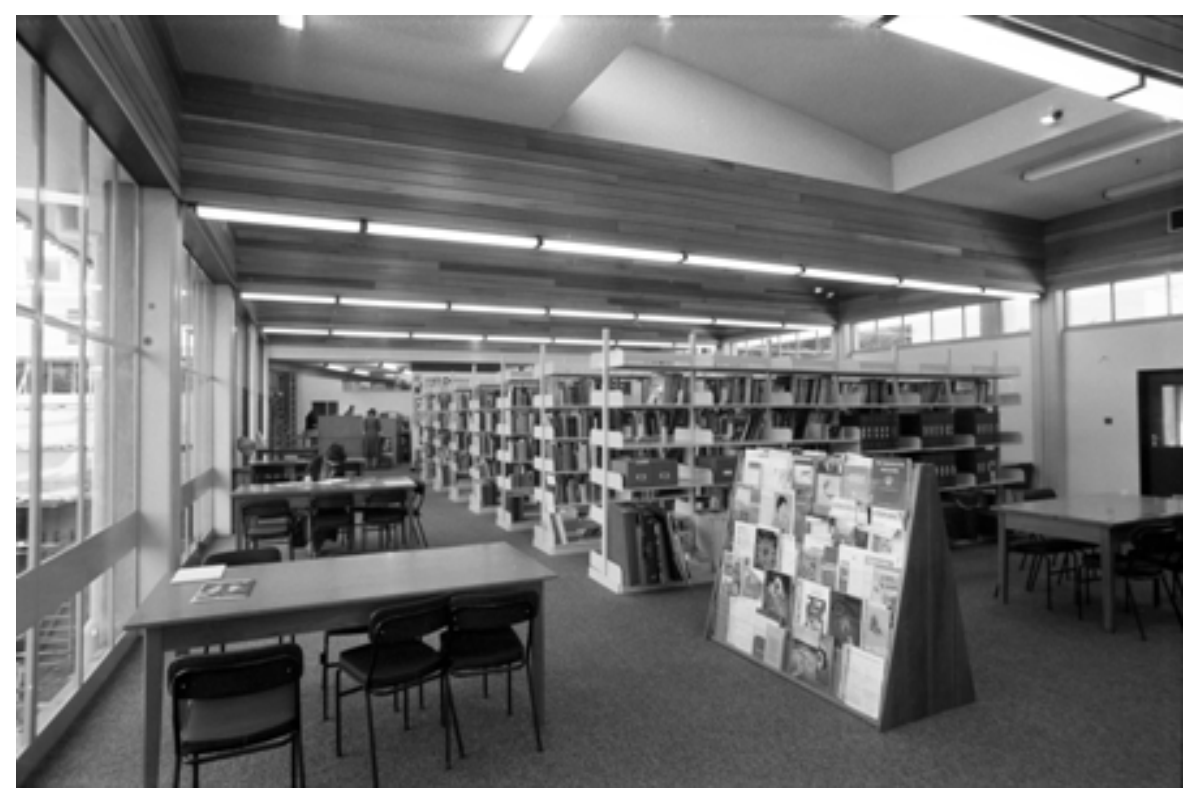

Figure 26. Fine Arts Library extension, view from the rear of the Library (1976) 


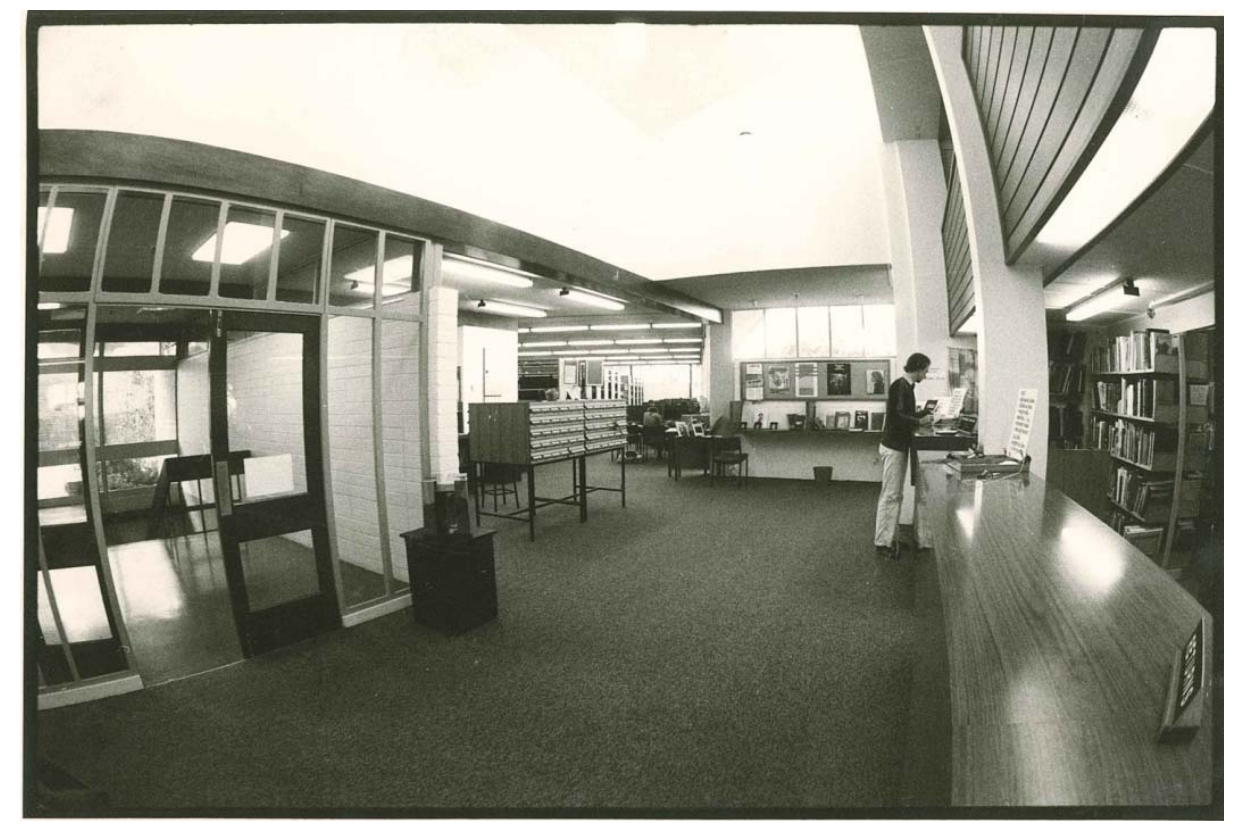

Figure 27. Fine Arts Library extension c.1977 with view of new entrance (left) and issuing and returns desk (right)

The Library’s overall design afforded flexibility for current layout and space for future growth. The design provided for individual and group study spaces (Langmead \& Beckman, 1970) and the mezzanine to house the special collections (Cummings, 1980; Henri, 2003). The new Library enabled staff and students to continue to exhibit their works and was a more conducive space in which to carry out critical and informal discussion, central to scholarly communication (Rusbridge, 1998). This helped to maintain the relationship between the Library staff and their users and the larger space provided the opportunity to create a more social and welcoming atmosphere. 


\section{Staffing}

In 1979 and 1986 Richards submitted requests for additional staff (Richards, 1979).

[The] present accommodation for the AUEL was designed in 1970 to meet 1985 requirements; then assessed as 5 full-time staff plus casual assistance. The full-time establishment has not been increased since the third full-time staff member was appointed in 1973. (Richards, 1986b)

These requests were not met and resulted in basic administrative responsibilities such as cataloguing and acquisition being constantly deferred. Between 1977 and 1985 the Library’s roll increased from 693 to 995 users (Richards, 1986b). In 1979 Richards noted that "similar libraries in Australia are enviously better funded and staffed: for example, Sydney College of the Arts Information Resource Centre, which caters for 460 students, has an annual budget of \$A45,000 and a full-time staff of 7 (1978 figures)” (1980, p. 1). The AUEL, in comparison, had a roll of 680 patrons, an annual budget of $\$ 17,000$, and a full-time staff of two, supported by two part-timers.

During the 1970s and 1980s the effects of stagnant staffing levels and low salaries were felt in tertiary libraries nationwide (The University of Auckland Library, 1981). As a result the AUEL was reliant on receiving special financial support from a number of sources including Art History (Fine Arts Library, 1976) and the Labour Department's Temporary Employment Programme. This support enabled the Library to employ 'assistants’ for special projects (Fine Arts Library, 1980).

Twenty years after the appointment of the first trained librarian the collection had grown from 1,000 volumes in 1962 to 30,000 volumes in 1982 (Fine Arts Library, 1983). The 1980s saw the collection expand to reflect the introduction of a number of courses in Fine 
Arts studio theory and Art History. New courses included Oceania Studies, Intermedia / time-based studies (Fine Arts Library, 1983), the History of Photography in New Zealand and Women in Art. Art theory, art historiography and the computer arts also became popular areas of study as suggested by Jane Dodd, who worked intermittently in a number of full-time and part-time positions from 1987 to 2008 (personal communication, April 4, 2011). To reflect these changes the Library continued to create bibliographies to facilitate research (Cole, Armitage, Richards, \& Auckland University Library Staff Association, 1974; Fine Arts Library, 1981). In addition, the Library introduced 'seminars' to support Art History Masters students in the creation of bibliographies and thesis preparation (Fine Arts Library, 1987, 1989).

\section{Staff and Students Relationships}

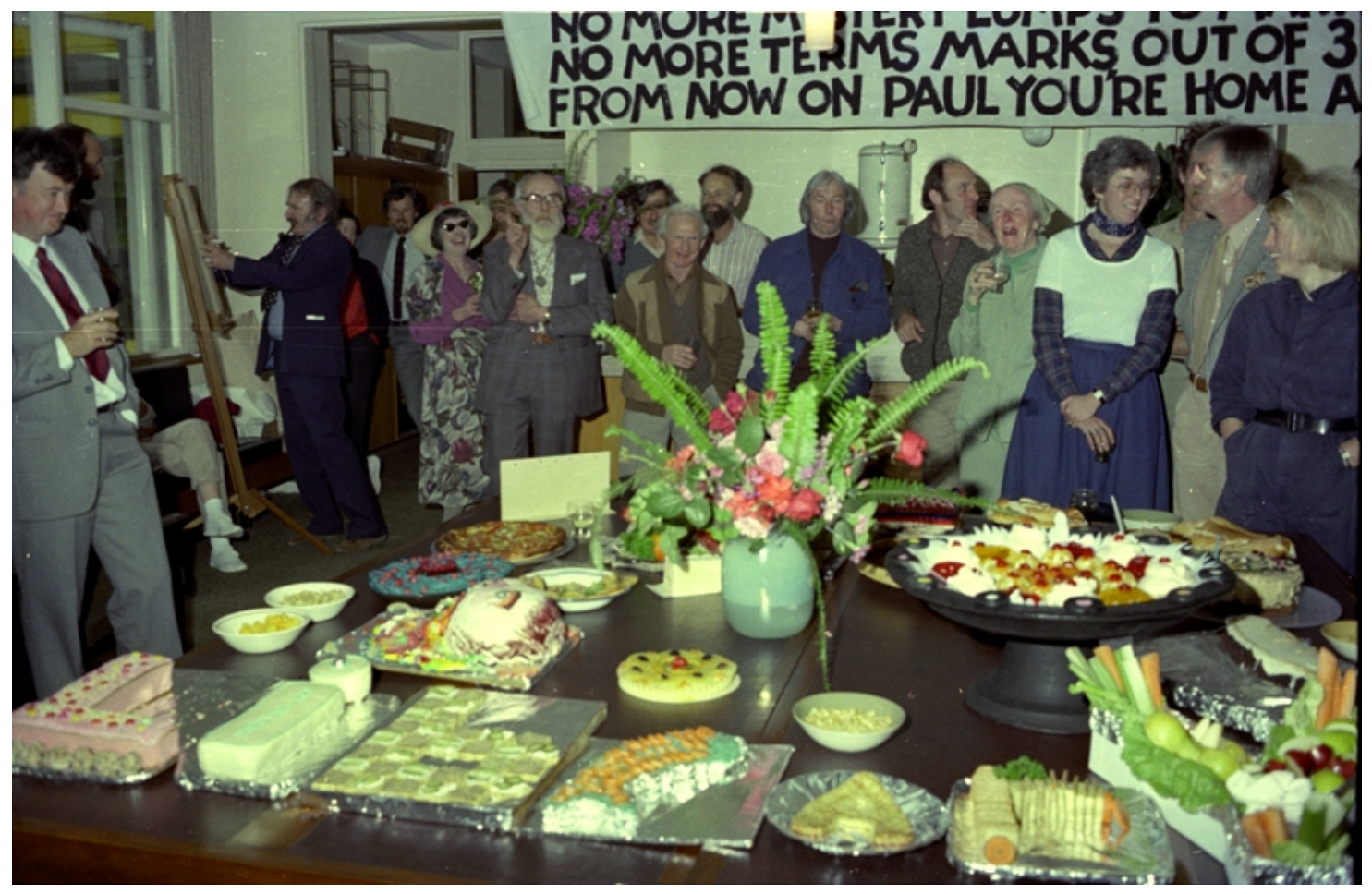

Figure 28. Professor Paul Beadle's farewell in the Elam Staff Common Room (1982) 
During the 1980s Library continued to have a strong relationship with Elam staff and students, as the image from Beadle’s farewell attests (Figure 28). The word 'Library’ spelt out with food items, in the foreground, suggests a sense of fun and camaraderie amongst the staff — a truly special tribute to Beadle’s “sympathetic encouragement” of the Library (Fine Arts Library, 1982, p. 1). Dodd confirmed that:

the Library was really pivotal to the 'Elam' experience. The students used the Library...extensively and...it probably wasn’t quite so much with Art History but I think...[that Library staff had] so much more...daily contact than you would get nowadays...there was a real solid connection. (personal communication, April 4, 2011)

Up until the mid 1990s the fact that the AUEL was the only place that Fine Arts and Art History students and staff could access all the resources relevant to the subjects they were studying created a strong connection between the Library and their patrons (L. Stone, personal communication, March 15, 2011; J. Dodd, personal communication, April 4, 2011).

To support the curricula the Library continued to add to their special collections with the completion of historical indexing projects (Fine Arts Library, 1983) and the creation of the Elam Archive (Fine Arts Library, 1981) and the artists’ book collections. The archive, partially funded by Elam until the mid-1990s (The University of Auckland Library, 1993), consisting of public records and personal research papers relating to the Elam School of Art (1890 - present), remains a significant resource for the School and researchers alike.

From the mid-1970s collections of artists' books became synonymous with art libraries (Sammon, 2006). A visit by Hoffberg, an artists’ book expert, in 1982 stimulated the 
AUEL to create of an artists' book collection at the AUEL (Fine Arts Library, 1985, 1986;

Richards, 1983b, 1984). The collection, established to provide students and staff with examples of a range of artistic practice, mainly acquires works created by former and current Elam staff and students. In 1988 Assistant Librarian Gail Keefe (appointed in 1987) won the first David Wylie prize for her essay on Artists’ books (Keefe, 1988). The artists’ book collection currently consists of over 300 items from 1960s through to today.

\section{Automation}

Automation, or the computerisation of the library catalogue and services, was the means by which unwieldy academic library collections became more accessible to core users (Thompson, 1982, 1983). In the international context automation was initiated during the late 1960s in North American, the early 1970s in Britain (Hunter, 2006) and the early 1980s in Australia (Peake, 1981). In contrast, The University of Auckland Library has been described as “a latecomer to library automation” (Wainwright \& Trask, 1993, p. 22). Automation had been first discussed at AU in1971 and interestingly in New Zealand during the 1960s (Robertson, 1968; Sutch, 1965; The University of Auckland Library, 1990). The AU acquired its first multi-user microcomputer in1984 (Nuttall, 1984) and joined the New Zealand Bibliographic Network (NZBN) a year later (The University of Auckland Library, 1986). This New Zealand wide network enabled the participants to pool knowledge, technical expertise and data (Heath, 2006; C. Wilson, 1984). In 1989 The AU purchased the Northwestern Online Total Integrated System better known as NOTIS (Beverley, 1989). This integrated automation software enabled the Library to create an online catalogue, 
AUCat, which was made publicly accessible through the University's Ethernet in 1990 (The University of Auckland Library, 1991).

Durey envisioned that the introduction of the NZBN and the onset of automation would allow the divisional libraries to become more 'interdependent' (Durey, 1984). However, access to the network only affected the libraries serviced by the General Library Cataloguing Department. The AUEL, which catalogued its own items, was therefore not included in the computer network until 1991.

Delays in automation were most likely a consequence of the dispersed nature of the organization, as the arrangement of AU is unusual compared to other New Zealand tertiary libraries. In 1993 The University of Auckland consisted of AU and 14 divisional libraries (The University of Auckland Library, 1994; Wainwright \& Trask, 1993) while the University of Canterbury, Victoria University of Wellington and the University of Otago each had a main Library and three or four divisional libraries. The purchase and ‘commissioning' of an automation system was implemented at Canterbury in 1985 and 1986 (University of Canterbury Library, 1986, 1987), at Victoria during 1987 and 1988 (Victoria University of Wellington Library, 1988, 1989) and Otago in 1989 (The University of Otago Library, 1989). 


\section{Chapter Four: 1990-1999}

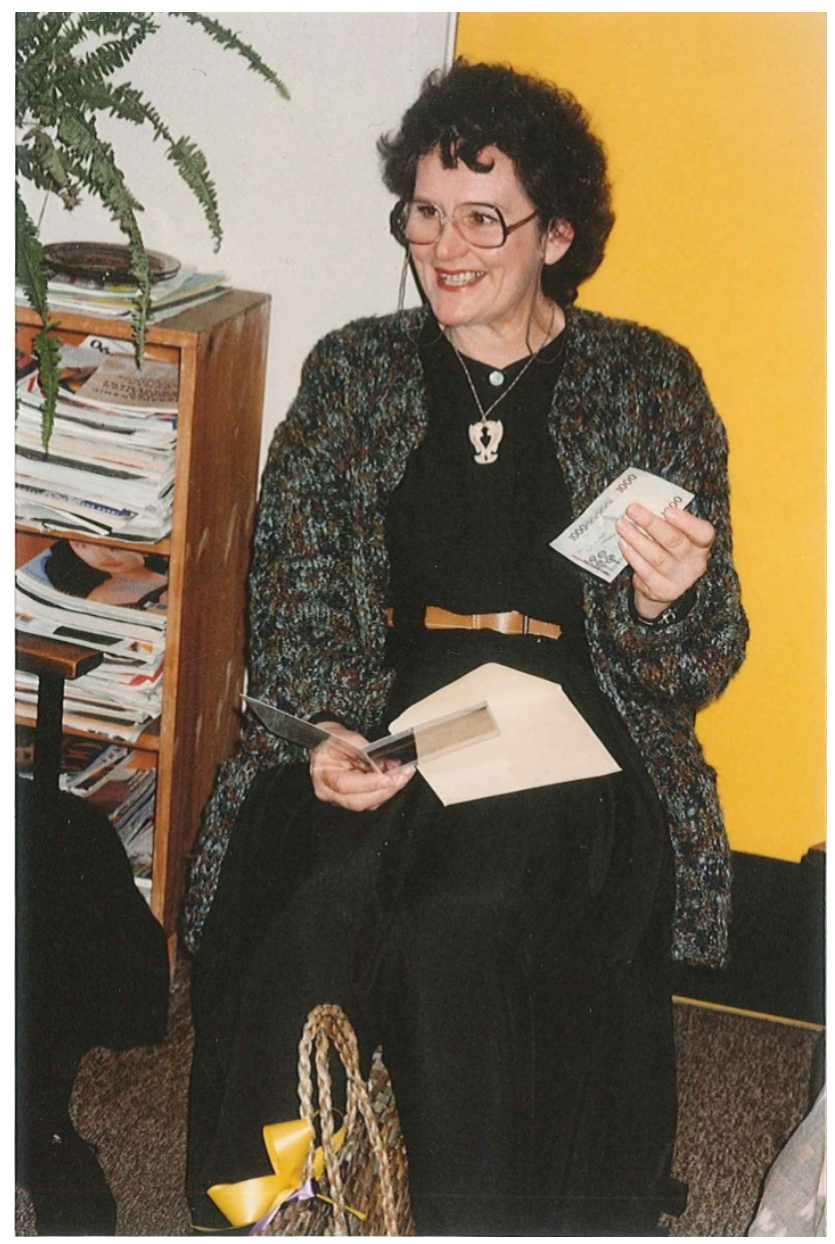

Figure 29. Valerie Richards on her retirement (1990)

At Richards retirement in 1990 (Figure 29) the AUEL the Library had developed over 25 years from a collection of 2,600 books, 400 periodicals and 2,200 prints in a space of 1,200 sq feet(Beadle, 1965b) to a collection of 30,000 books in a space of 6,500 sq feet (Richards, 1990).

Highlights of 25 years as Fine Arts Librarian? Most importantly, working with creative people ...Watching the collection grow to a stage where we can adequately serve the needs of undergraduates in Fine Arts and Art History... 
Friendly contact with art librarians and art booksellers around the world as well as in New Zealand. Not so great, perhaps the lack of staff to do all those things one would like to have done....But, it has been a very enjoyable time. (Porter \& Richards, 1990)

This was an end of an era. Gail Keefe (Figure 30), appointed as her replacement, ushered in the new era of technology. However, as succession planning was limited, the Library faced a brief but challenging period of transition. Keefe quickly found her feet supported by Jane Dodd, in an interim position, and Lynley Stone as Deputy Fine Arts Librarian (1990-1994).

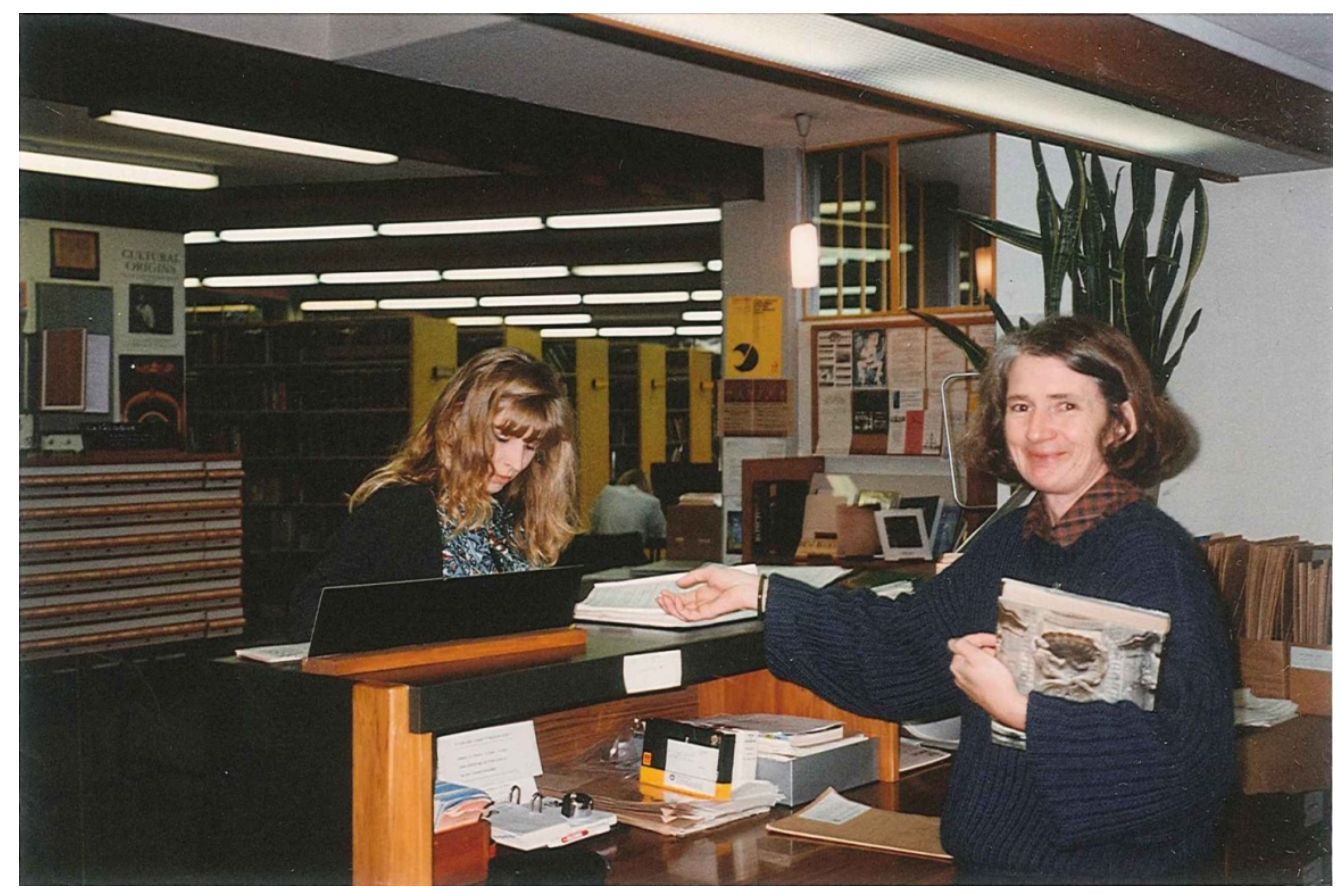

Figure 30. Gail Keefe serving a patron (1990) 


\section{Automation and the Collection}

In 1991 the retrospective cataloguing commenced. Nicole Jackson, Library Assistant during this time, remembered Stone’s direction of the project, “[she] managed this task brilliantly, drawing on the skills of individuals; her warmth, enthusiasm and appreciation of each person's contribution ensured that a massive project was accomplished with tremendous efficiency” (personal communication, March 18, 2011). In 1991 the AUEL was linked to NOTIS but not the NZBN (The University of Auckland Library, 1992) so the AUEL staff had to walk over to the AU Cataloguing Department to use one of their two cataloguing logins, with each search taking two or three minutes to process (L. Stone, personal communication, March 15, 2011).

Black has argued that instead of being passive onlookers librarians have "embraced the informization of their practice” (2004, p. 30). The introduction of computers and the Library’s first online catalogue AUCat were exciting yet challenging milestones for the AUEL (The University of Auckland Library, 1992). The new command-driven catalogue improved the way the Library's collection could be searched but provided challenges as described by Stone:

Keyword was the killer...When we automated we had to teach the people how to use the OPAC... and that transformed everything...nobody was used to using computers they didn’t understand the command language and it was even worse than trying to teach them the card catalogue (personal communication, March 15, 2011).

Automation of the AUEL catalogue was completed in 1995 with the Library became fully automated for lending and an electronic link to the NZBN was finally established. (The University of Auckland Library, 1996). During this early period of automation the teaching 
faculties of Universities around the world acknowledged that they could not keep pace with the changing technological environment (Jenkins, 2005). At the AUEL the same applied with the Library taking the lead in training students and staff in the new technologies. To ease the transition the card catalogue remained available for some time (Edwards, 1997). As the images from 1993 and 1994 attest, the Library was still very much a paper-based, manual world (Figures 31, 32 and 33).

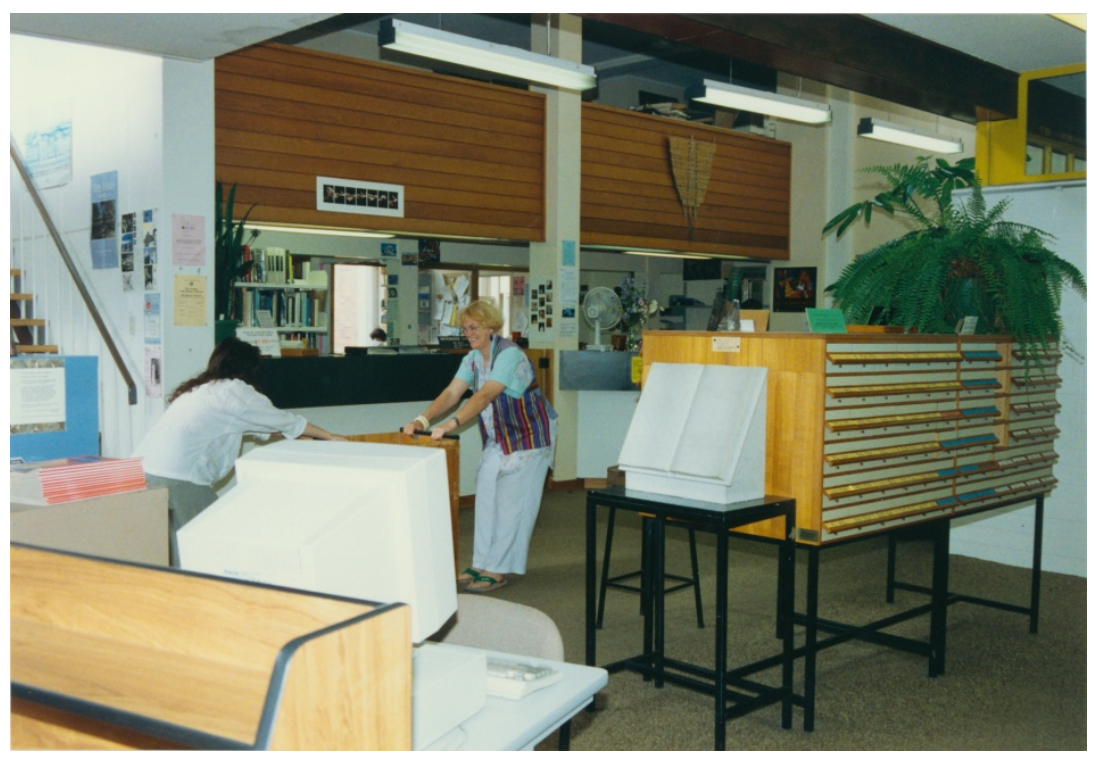

Figure 31. Card catalogue, front desk arrangement (c.1990-1994)

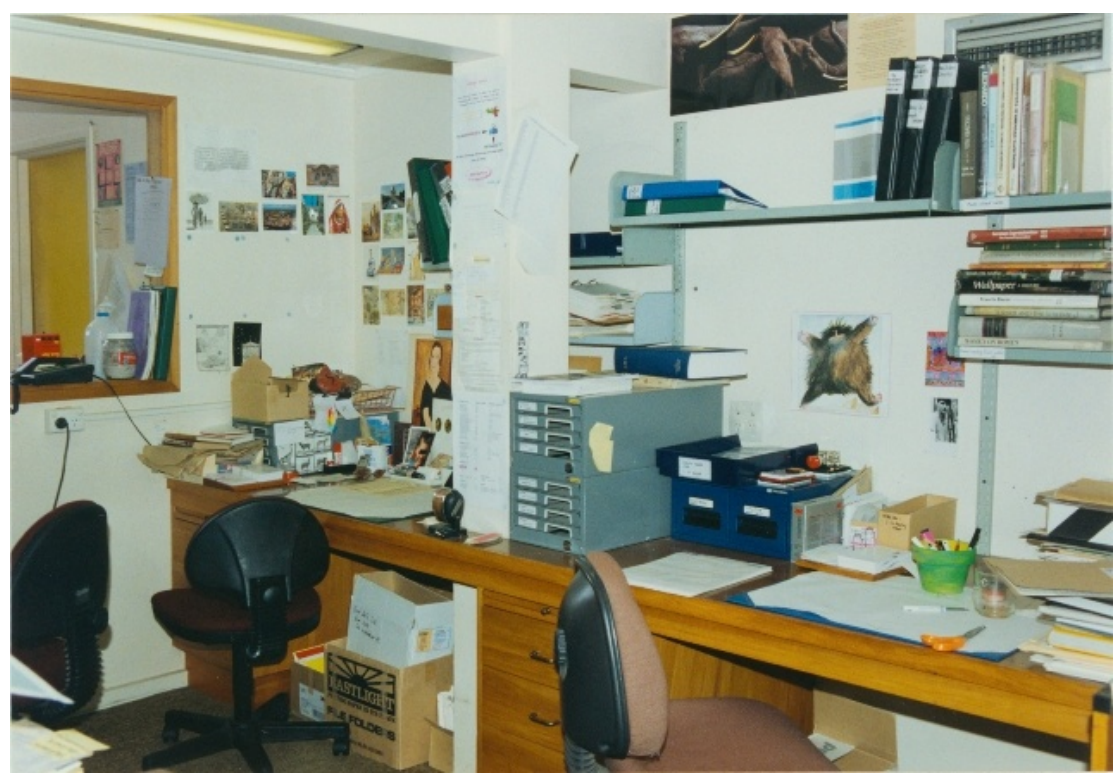

Figure 32. Library Assistant desks (c.1990-1994) 


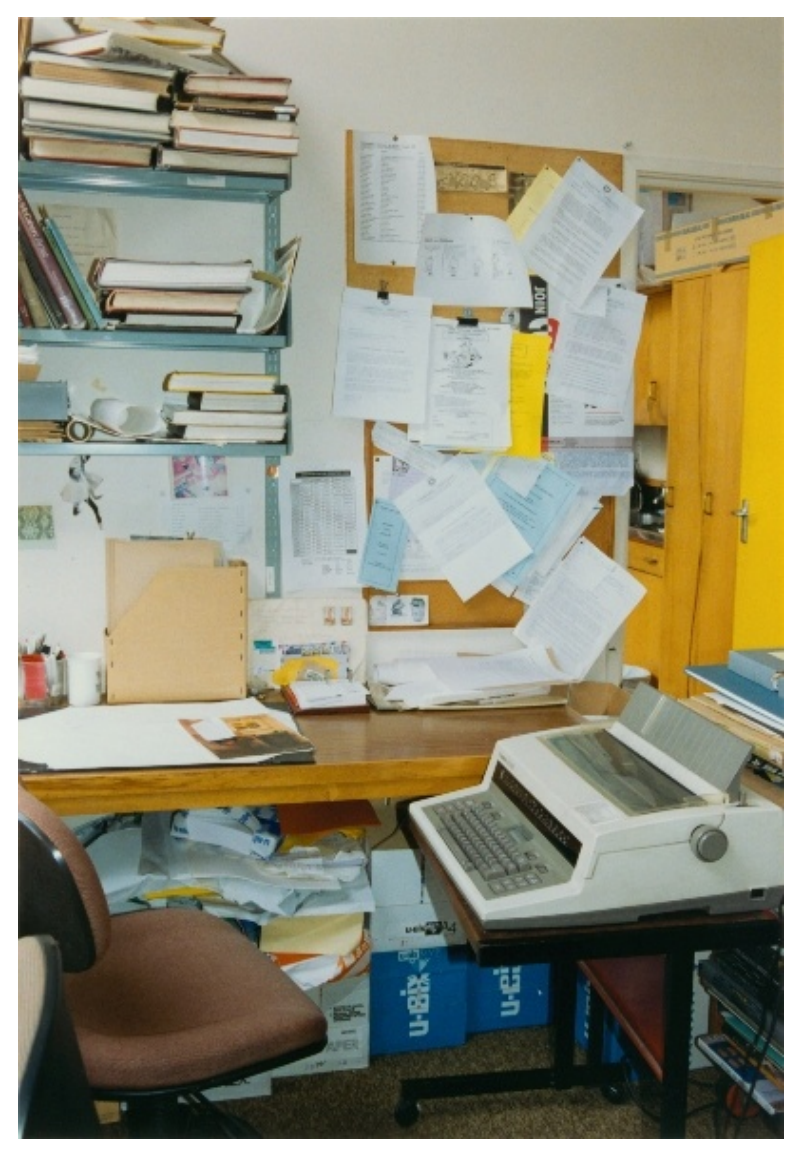

Figure 33. Typewriter in backroom of the Fine Arts Library (c.1990-1994)

In 1993 the AUEL had 17,500 monographs and had 200 current serial subscriptions, with the acquisition’s budget totalling $\$ 80,000$. Twenty five percent of this budget was spent on serials, the cost of which increased annually. Keefe identified a number of gaps, including the lack of books on sculpture and monographs on new artists (Keefe, 1993). By New Zealand standards the quality of the Library's collection was good and the budget was more than sufficient (L. Stone, personal communication, March 15, 2011). 
Staffing 1990-1994

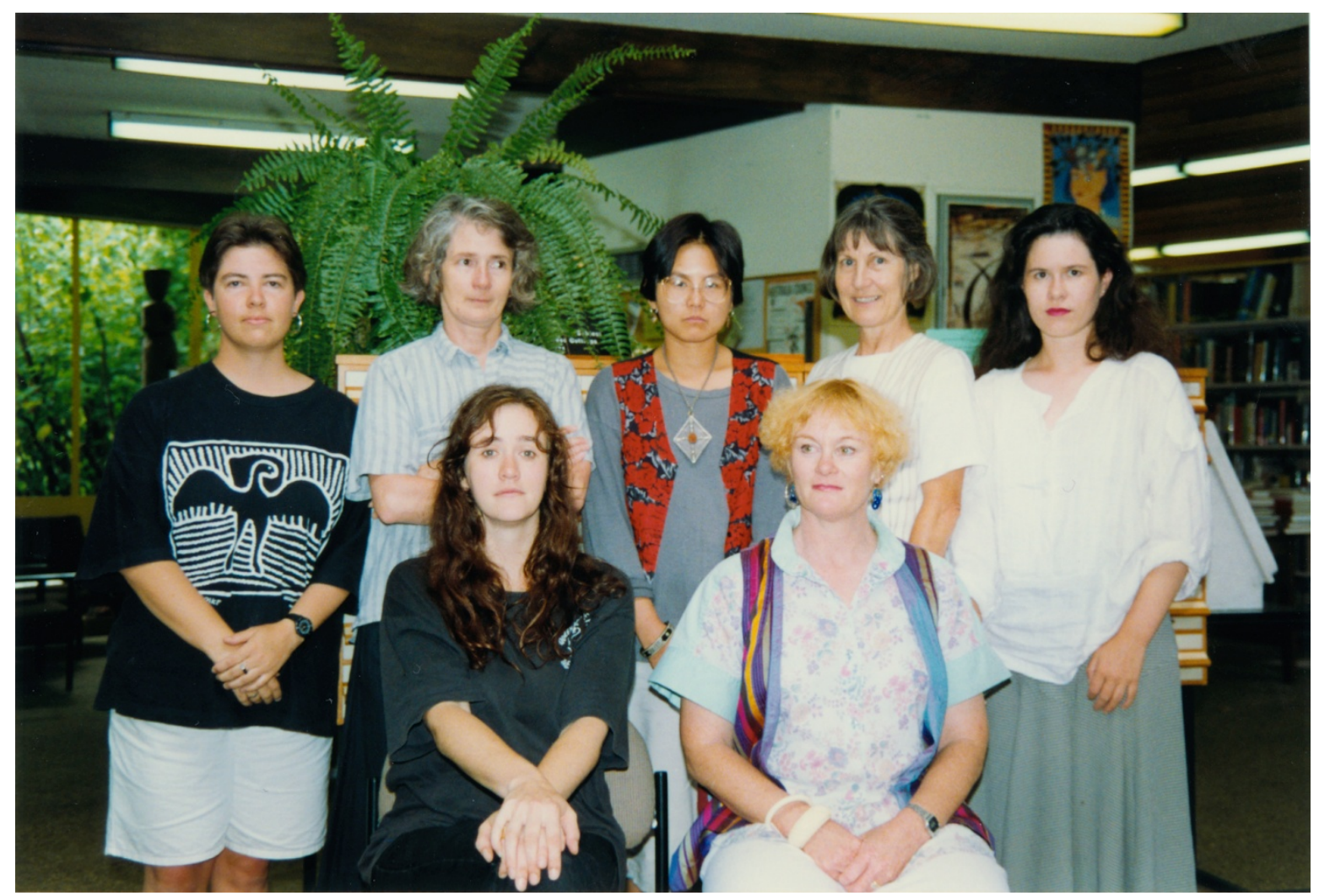

Figure 34. Fine Arts Library staff (c.1990-1994)

Between 1990 and 1995 automation was the AUEL's core focus. However, the Library’s regular tasks, such as book and serial selection, cataloguing, desk duty, user education and indexing, continued as usual. In 1993 the full-time staff consisted of the Fine Arts Librarian, an Assistant or Deputy Librarian, and a Library Assistant. The part-time staff included three part-time assistants, whose hours ranged from 20 to 28 hours per week, and several casual desk staff (Figure 34). An increase in Library use, with the doubling of the Elam Studio One intake from 50 to 100 in 1993, combined with pressures of the automation project, highlighted the need for additional staff (Keefe, 1993). "If you needed 
more staff you had to make a very strongly argued case...it almost always got turned down” (L. Stone, personal communication, March 15, 2011)

\section{Culture}

During the early 1990s the Library shifted from "being a silo where everything was manual to being an integrated part of the University Library system”. However, "within the culture of the organisation...it was actually...very stable” (L. Stone, personal communication, March 15, 2011). The period saw the Library develop a flatter more egalitarian structure, still apparent today (J. Wild, personal communication, March 28, 2011).

Several Library staff had strong informal relationships with individuals around the University, especially in the AU (L. Stone, personal communication, March 15, 2011). While these personal relationships helped to provide connections to the wider organisation, some staff felt less involved in the wider Library community (J. Dodd, personal communication, April 4, 2011). As Stone went on to suggest it was "like a frontier society" (personal communication, March 15, 2011).

Keefe encouraged staff to have an in-depth knowledge of the collection and afforded them time to discuss and debate current art trends and topics. As Stone remembered:

We had half hour tea breaks...[at] morning and afternoon and that was the culture of the place... That was when we heard what the graduate students were telling us. That's when we had the debates about art versus craft...If you weren’t...talking to people in the tea room, you would have a pile of books or magazines from the collection...that you were flicking through...Gail told us that we had an obligation 
to be familiar with every image in every book and magazine, and we were. (personal communication, March 15, 2011)

The long tea break can be identified as a 'ritual' (Trice \& Beyer, 1987) that helped to unify staff and create a sense of belonging. The team also included student artists who were "intelligent, creative, alternative thinkers" who added positively to the work dynamic and who acted as "our conduits out into the School” (L. Stone, personal communication, March 15, 2011). Employing staff who have a background in art history or are practising artists or students of Fine Arts or Art History is an ongoing approach to employment and demonstrates that the Library is committed to employing permanent and part-time staff with not only theoretical but practical knowledge of the subjects ("Special Issue: Art librarians as artists," 1992).

It is significant to note that Elam's 1991 external review only provided one and a half sentences, under the heading "Equipment and Library", to praise the Library as a great resource (The University of Auckland, 1991). As Keefe suggested "The fact that the Library was considered as part of the equipment of the School illustrates the low profile the Library system has in the University community” (1993, p. 6).

\section{Review of The University of Auckland Library (1993)}

A review of The University of Auckland Library was undertaken in 1993 (Wainwright \& Trask, 1993). This review emphasised the need to determine the level of funding provided by The University to the Library (Wainwright \& Trask, 1993). Other issues included a lack of planning and physical infrastructure to support Library automation and the need for increased organisational cohesion. 
From the 1930s until this time the AULS was administered through a centralised organisational structure, with managers of the individual branch libraries reporting directly to the University Librarian (Johnson, 1988; Rowan, 1999; Wainwright \& Trask, 1993). This created a strong relationship between the University Librarian and the heads of departments or divisional libraries (V. Richards, personal communication, April 8, 2011; L. Stone, personal communication, March 15, 2011). However, this hierarchical arrangement also resulted in fragmented organisation, with each branch Library in effect a silo within the AULS.

The 1993 review recommended the introduction of Associate Librarians, responsible for managing different areas of the AULS. It also recommended that the City Campus "be based on broad subject-based organisational groups” (Wainwright \& Trask, p. 75). This reflected the trend towards merging and 'clustering' libraries, prevalent during the late 1980s and early 1990s (Crockett, 2000).

In 1994, in line with the Review's recommendation to centralise administrative tasks, the AUEL transferred cataloguing to the AU (The University of Auckland Library, 1995). This took a significant amount of pressure off the AUEL's senior staff (The University of Auckland Library, 1995). Despite feeling a sense of “relief”, staff expressed some reservations. Jackson, who became Deputy Librarian in 1994, recalled that, “we still monitored each record to ensure the Dewey entry was appropriate, checked subject headings and made sure that all New Zealand artists were listed” (personal communication, March 18, 2011). 


\section{Teaching}

The 1990s saw changes in the way tutorials were presented (The University of Auckland Library, 1992). Keefe identified that the old approach "did not engage the attention of students, so very early in the piece I formulated worksheets for students. They completed these under the guidance of Library staff ...This was much more successful” (personal communication, April 2, 2011). Senior library staff also had free range to develop the content of subject specific tutorials (N. Jackson, personal communication, March 18, 2011) and "Elam staff would often bring their class to the Library and attend tutorials with their students, which was a great endorsement” (G. Keefe, personal communication, April 2, 2011). Interestingly, Stone noted that the number of non-course specific reference queries during the early 1990s was low (personal communication, March 15, 2011). However, this was to change after the mid-1990s with the increase in postgraduate enrolments.

This development was paralleled by a growth in electronic resources. The Library Electronic Academic Resource Network (LEARN) was introduced in 1996 providing a more accessible entre into the Library's electronically available material (The University of Auckland Library, 1997). The Art Index and ARTbibliographies Modern (The University of Auckland Library, 1995), core AUEL resources, were now available on CD-ROM and later online (N. Jackson, personal communication, March 18, 2011). The automation of the AUEL's in-house New Zealand art indexes (The University of Auckland Library, 1995), initially only accessible within the Library, was a response to these technological developments (J. Dodd, personal communication, April 4, 2011; N. Jackson, personal communication, March 18, 2011). The investment in the Library's electronic infrastructure was a reflection of the increased funding the Library received from 1995 (The University of Auckland Library, 1995). 


\section{Fine Arts Library Review 1998}

The appointment of Janet Copsey as the University Librarian in 1998, provided the impetus to reassess the AULS (The University of Auckland Library, 1999). An operational review of the AUEL was completed alongside the Engineering and Architecture Libraries, resulting in the restructuring of the three libraries, under the banner of the Engineering, Architecture and Fine Arts Group. This new geographical association, alternatively known as the Symonds Street Group, was to be managed by a divisional librarian, with Jane Wild being appointed in August 1999. 


\section{Chapter Five: 1999-2007}

\section{Culture}

For nearly 40 years the Library had developed a culture of autonomy and individuality. The restructuring of the Library (The University of Auckland Library, 1999) came as a shock. The grouping of the Library with two other divisional libraries and the introduction of a Divisional Library Manager was seen as a challenge to the autonomy of the AUEL. In the initial period Wild was faced with implementing changes which were not wholeheartedly supported. This reflects the independent mentality common to divisional libraries (Bottorff, Glaser, Todd, \& Alderman, 2008; Crockett, 2000; Jurkowski, 1997). After some adjustment, staff saw the restructure as a positive change, enabling the streamlining of tasks and the provision of consistency across the AULS (Figure 35).

Two new positions of Client of Client Services Librarian and Subject Librarian were introduced (The University of Auckland Library, 1999). The redefinition of positions enabled the creation of consistent job descriptions throughout the AULS. Staff could now focus on creating and maintaining value added services and products which focused on the needs of its core users (Frank, 1999), an example being the digitisation of Art History’s slide collection. The Art History Images Database (AHID) was a project championed by the Head of Art History Elizabeth Rankin and realised by the AUEL and the AULS Digital Services (The University of Auckland Library, 2001, 2002). The creation of this electronic resource is consistent with other art research Libraries (Baca \& Tronzo, 2006; Dirst, 2003) and reflects the changing needs of the Library’s users. While the reorganisation impacted the Library on an administrative level, the culture remained the status quo. 


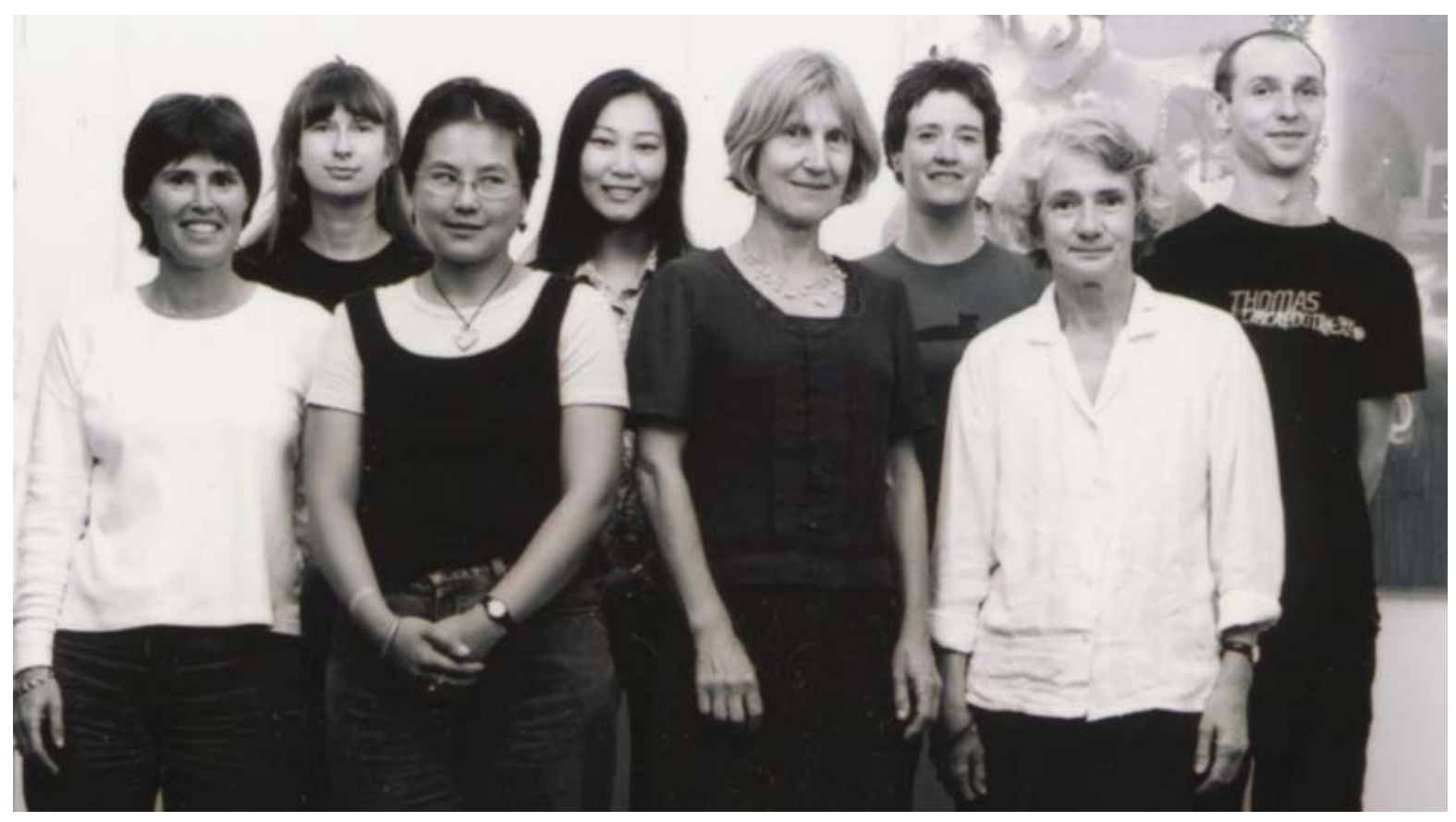

Figure 35: Fine Arts Library Staff Photo taken by Paul Gilbert (c. 2001)

\section{Accommodation and Finances}

In 2000 the AU Library's collections budget increased by 20\% (The University of Auckland Library, 2001) reflecting the increased profile of the Library within The University of Auckland (The University of Auckland Library, 2003). In turn, the AUEL's acquisitions budget increased every year between 2001 and 2004 (The University of Auckland Library, 2002, 2003, 2004, 2005), and as a consequence the collection grew considerably. To accommodate this growth the front entrance and reading areas were redesigned in 2001 (Figures 36 and 37) and the serials and monograph shelving reorganised in 2004. 


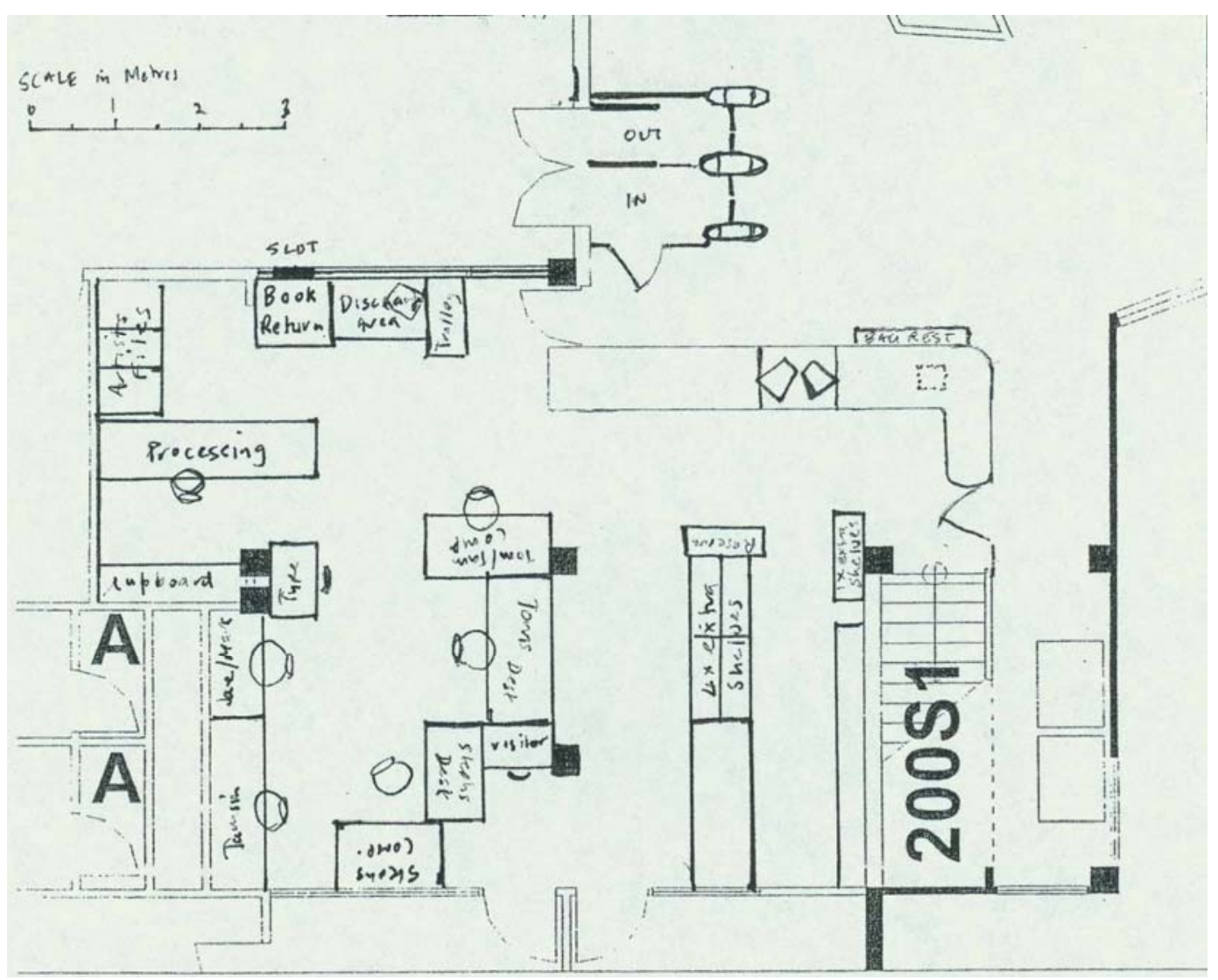

Figure 36. Plans for the reorganisation of the front desk in 2001.

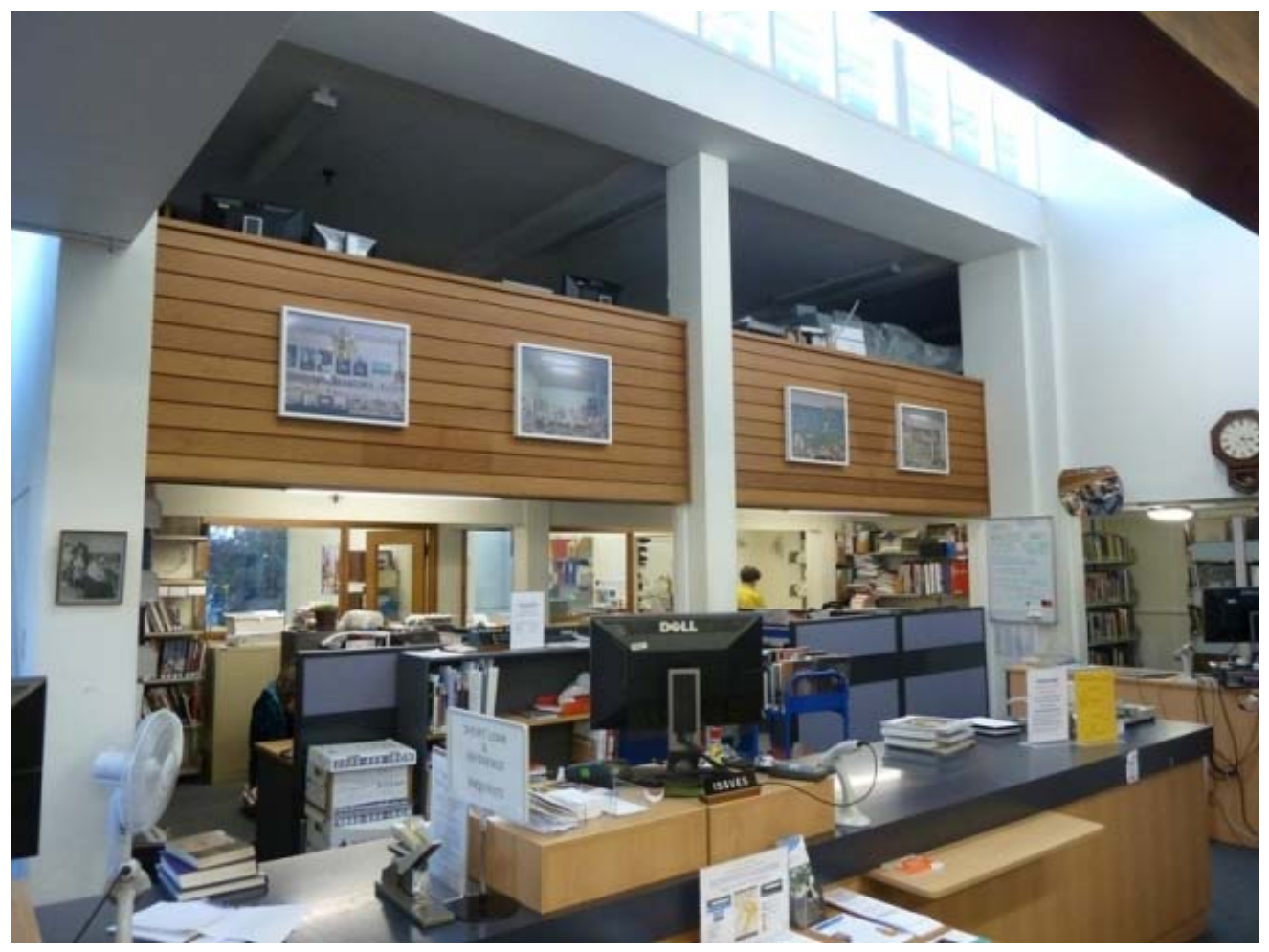

Figure 37. Front desk of the Fine Arts Library (2011) 


\section{Bachelor of Visual Arts}

A partnership between Elam and the Manukau Institute of Technology’s (MIT) School of Visual Arts was created in 2001. The new Bachelor of Visual Arts (BVA), taught at Manukau Campus, provided students membership of both the Manukau School of Visual Arts Library and the AUEL (Govender, 2005). Every year BVA students are provided a tour of the Library with the BVA lecturers being great users of the Library's special collections. Remote access to the electronic resources and the twice weekly intercampus delivery service also enabled access to the AUEL's collection. The BVA programme has been suspended as of 2011, with The University supporting current students to complete the programme (The University of Auckland, 2011).

\section{National Institute of Creative Arts and Industries Libraries 2004}

In 2004, the National Institute of Creative Arts and Industries (NICAI), a Faculty combining the disciplines of Music, Dance, Architecture, Planning and Fine Arts, was established (The University of Auckland Library, 2005). Wild's role was realigned to the management of the NICAI Libraries (Music and Dance, Architecture and Planning and AUEL), and the Special Collections at AU. This more meaningful grouping of subject related collections has enabled increased collaboration between the AUEL, its Faculty partners and the wider library system. The Fine Arts Library Committee was subsumed into the NICAI Library Committee, with Elam and Art History staff representatives.

During this same year, and largely as a consequence of the 2001 Faculty review, Elam’s studio structure was reorganised (The University of Auckland, 2006b). The School shifted from being a structure of seven 'core sections' to being one organised on an 
interdisciplinary model (The University of Auckland, 2001). Elam, while drawing on the expertise of the Department of Art History, tailored a course on art theory (Critical Studies) to suit the needs of its own students. The following three years were difficult for Elam, and the other Schools within the fledgling faculty, with a number of grievances raised in regards to NICAI’s administration (Cocker, 2007; Copland, 2007; "Cracks appearing in the foundation," 2007; Grunwell, 2006; F. Walsh, 2007, November). However, this unrest did not have a significant impact on the Library.

The curricular changes at Elam between 1999 and 2007, increased focus on contemporary art theory, interdisciplinary research and postgraduate study all influenced the Library’s collection and services (The University of Auckland Library, 2002, 2004). These developments included the creation of the Photobook collection (The University of Auckland Library, 2006) and the cataloguing of the Library’s ephemera (Jackson, 2006). The majority of undergraduate course related tutorials, taught for Art History, Elam and BVA students, focused on bibliographic instruction, including the use of the catalogue and a number of electronic indexes or databases. As these courses were taught in the Library they also included practical elements, such as viewing items from the special collections (Taraba, 2003) and searching for a book on the shelf. One-on-one sessions with postgraduates continued as before.

In 2007 the two in-house indices, the New Zealand Art Press Cuttings Index and the New Zealand Art Journal Index were merged to create the online Index to New Zealand Art (INZART) (Irwin, 2008/2009; The University of Auckland Library, 2007). Some staff did not initially support this project (N. Jackson, personal communication, March 18, 2011), due to the idiosyncratic approaches in indexing these two resource types. However, as a result of careful management by Wild, and support from Digital Services and the 
Cataloguing Department, the initially disconnected databases became a well-defined and 'streamlined’ electronic research resource (N. Jackson, personal communication, March 18, 2011).

\section{The separation of Elam and Art History 2006}

In 2006, the AUEL's two most important institutional partners broke curricular ties. The changes to the Fine Arts academic regulations, which came into effect in 2006, meant that Art History courses were no longer compulsory for Fine Arts students (The University of Auckland, 2005). The flow-on effect on the Library’s collection and services were not as a significant as the impact on Art History.

In this same year, and following the recommendations of the 2005 departmental review, Art History moved from 58 Symonds Street, which was just above Elam, to Arts 2, a building at 18 Symonds Street, ten minutes away. While students of Art History remain major users of the AUEL, the Library has experienced a significant drop in the number of academic staff from Art History visiting the Library (S. Brown \& Swan, 2007; Rusbridge, 1998). The adoption of information technologies by academic libraries and the scholarly community alike has provided a significant shift in the way libraries are accessed (Borgman, 2000; Schonfeld \& Housewright, 2010). As Collins suggested:

that technology reduces the number of patrons who actually walk through the door of art libraries. Statistically this might appear worrisome...In fact, patrons who are able to find answers from their own desktop or from simply e-mailing a librarian almost always remain loyal supporters of the library (Collins, 2003). 


\section{Chapter Six: 2008 - Present}

\section{Culture}

Following the retirements of Keefe and Jackson in 2007, Wild moved into the Library, taking up the dual positions of manager of both the NICAI Libraries and the AUEL. Wild has promoted a culture of innovation and collaboration with other departments in the Library and the wider University. Library staff have been nominated for a number of awards and successes are celebrated. These 'rites of enhancement' provide both a model of accepted and desired behaviours for the Library's staff and an opportunity to publicise the accomplishments of the AUEL to the wider organisation (Trice \& Beyer, 1987). Regular meetings of sub-groups and the wider group encourage a culture of professionalism, accountability and consultation.

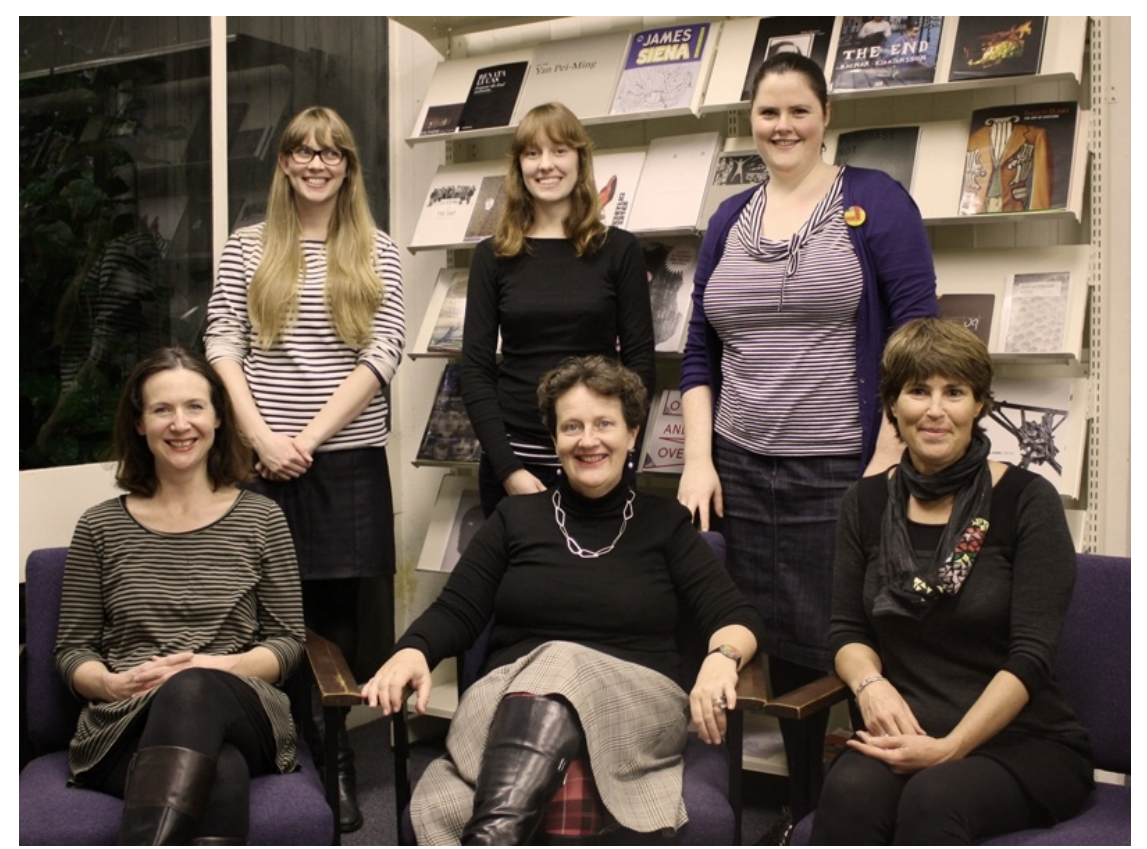

Figure 38. Fine Arts Library Staff (2011) 
In comparison to larger libraries, the AUEL staff have, as in previous periods, have built stronger informal and arguably more personal relationships with their users. This is especially true in relation to the Elam students as the Library’s location provides the opportunity for staff to engage with the creative output of the students they support.

\section{Staffing}

The current staff consists of Wild, two Subject Librarians, a Client Services Librarian and three full-time equivalent Library Assistants. These roles are supported by five evening and weekend desk assistants. In addition to regular desk, reference and teaching services the Library focuses on the creation and maintenance of the INZART and AHID databases, completing inter-loans, and managing the serial, ephemera and special collections. The AUEL continues to focus on employing staff with specialist knowledge in either art history or the fine arts.

\section{The Collection: Electronic versus Physical}

Today 73\% of AU Library’s budget is spent on electronic resources and datasets (The University of Auckland Library, 2011) compared with 41\% in 2002 (The University of Auckland Library, 2003). The purchasing and use of these is supported, promoted and celebrated by the AUEL which has become a 'hybrid library', relying on both electronic and physical resources (García \& Coso, 2006). However, while text can be readily supplied online, successful online image reproduction, important in the field of Fine Arts and Art History, can be more problematic (Carr, 2007; Henri, 2003; Mason \& Robinson, 2011). 
The printing of books and journals remains the preferred format for art publication. Due to the high cost of image reproduction many of these items are expensive and can only be afforded by a collection such as the AUEL. Professor Elizabeth Rankin, from Art History argues that "however many online sources there may be, there is no substitute for browsing on shelves (particularly with art books!) and finding new material. Our good students do this just as much as we do!” (personal communication, April 4, 2011). The AUEL's browsing statistics continues to equal the number of books issued. This aligns with the information seeking-behaviour of art library users (Frank, 1999; Hemmig, 2008; Layne, 1994; Mason \& Robinson, 2011; Pacey, 1982), illustrating that both the physical collection and the online collection play a complementary role in the support of the AUEL's core constituents.

\section{The Collection: Current Trends}

In the past five years as a result of shifts in curricula the Library's users are exploring a more diverse, contemporary and interdisciplinary range of research topics (Collins, 2003). This change has been reflected in the broadening of the collection development policy to include Museum Studies, Art Philosophy / Theory / Critical Studies and New Media (Fine Arts Library \& Wild, 2008). The enhancement and expansion of the AUEL's unique special collections has also remained a priority (J. Wild, personal communication, March 28, 2011), with the New Zealand Illustrators Collection acquired in 2009 (Passau \& Fine Arts Library, 2010a) and the finding aids for the Beverley Simmons art papers (Passau \& Fine Arts Library, 2009) and Post-Object art files (Passau \& Fine Arts Library, 2010b) now searchable through the Library Catalogue. 


\section{Information Literacy}

The AUEL is increasingly aware of the vital role it plays in educating its users on how to access, evaluate and synthesise information. The importance of libraries' role in teaching information literacy skills within academic courses has been well documented (Bundy, 2004; Chiste, Glover, \& Westwood, 2000; Dewald, Scholz-Crane, Booth, \& Levine, 2000). These pedagogical shifts have been recognised both within The University of Auckland Library (Carrie \& Mitchell, 2010; Zdravkovic, 2011) and the University as a whole (The University of Auckland, 2006a). The provision of tutorials and one-on-one student support at undergraduate and postgraduate level is a major focus for the two AUEL Subject Librarians. Library or information literacy tutorials are not on the main 'embedded' (Kobzina, 2010; Miller \& Pellen, 2004; Pritchard, 2010) in the Art History or Elam curricula, however, the AUEL's Subject Librarians work in close collaboration with a number of academic staff to teach assignment or course specific library and information literacy skills as part of a regular course lecture (Jenkins, 2005).

The Library also continues to run hour long course related tutorials for both Elam and Art History students, the majority of which are now taught in a purpose built training room at the School of Engineering. This has resulted in a more professional and time effective tutorial programme. It has however highlighted the need for the Library to have onsite access to such an instructional space (Figure 39), a factor also an issue in other art libraries (Craig, 2003). 


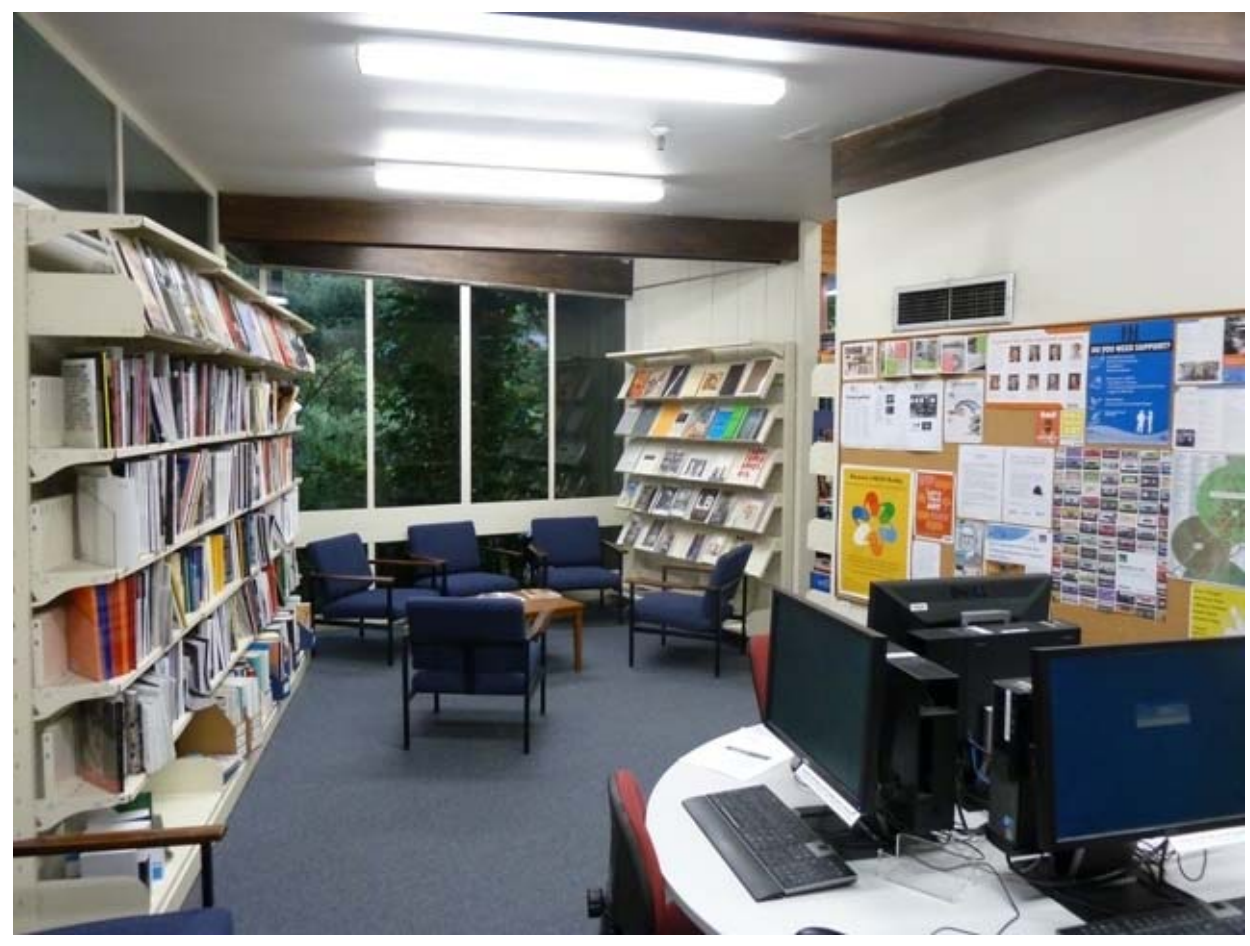

Figure 39. The new books and serials reading area and three of the AUEL's eight public computers (2011)

\section{Physical Space and Collection Management}

The emphasis on online resources has meant that the AULS physical collections have been described as a "steady-state” (Copsey \& The University of Auckland Library, 2011, p. 17). The steady-state concept describes the offset of the acquisition of new books by withdrawing or transferring underused items to storage facilities (Cannon \& Christie, 2005; Genoni, Merrick, \& Willson, 2006). Over the past decade a number of collection management projects have been carried out at the AUEL to increase shelf space. Additional shelving has reduced study space from 80 , when the library first opened in 1976, to approximately 45 today. Figures 25, 40 and 41 illustrate the ongoing accommodation issues. The AUEL currently houses 51,000 books, 452 theses, and 13,000 volumes of serials. With an on average 30 new books coming in per week the Library's shelf space is now at full capacity. 


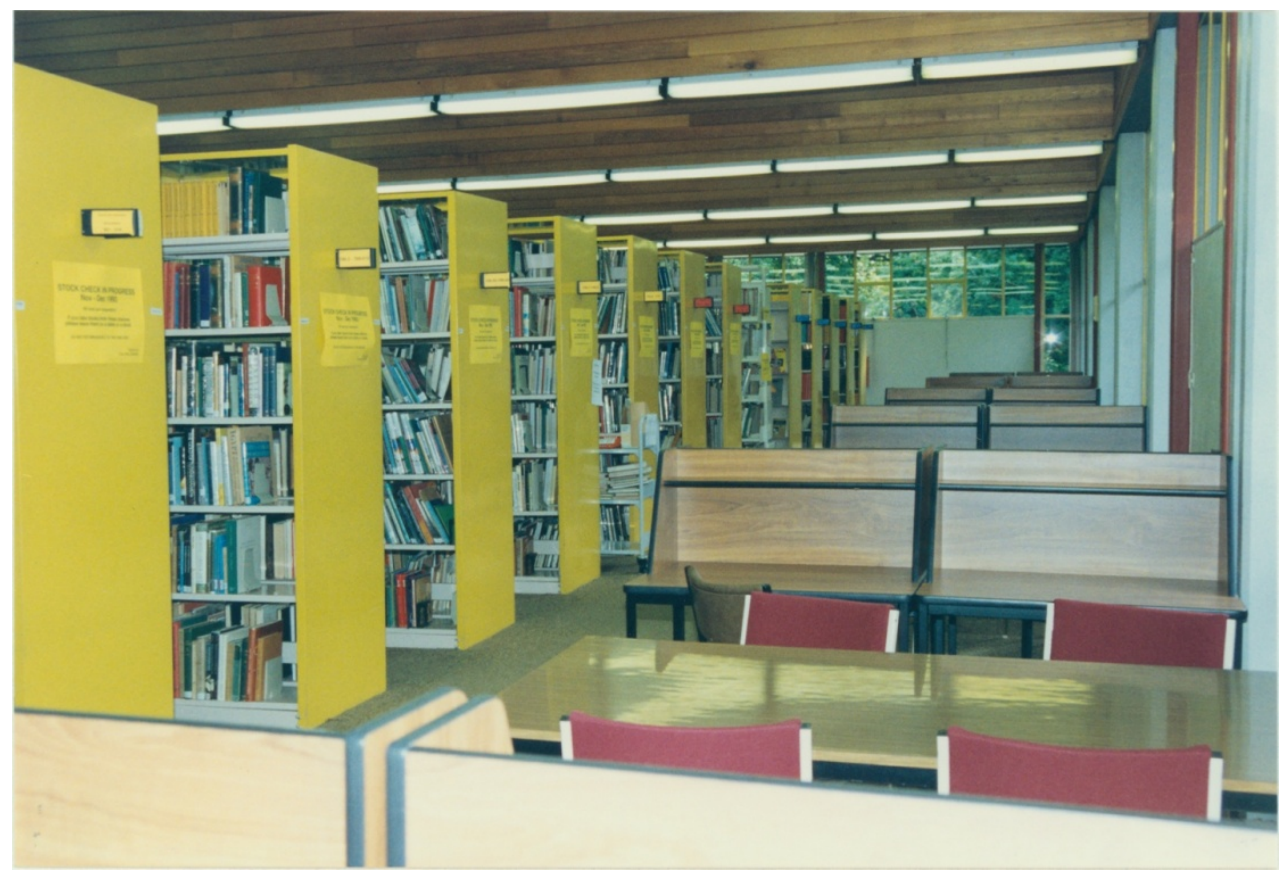

Figure 40. Fine Arts Library book stacks (c.1990-1994)

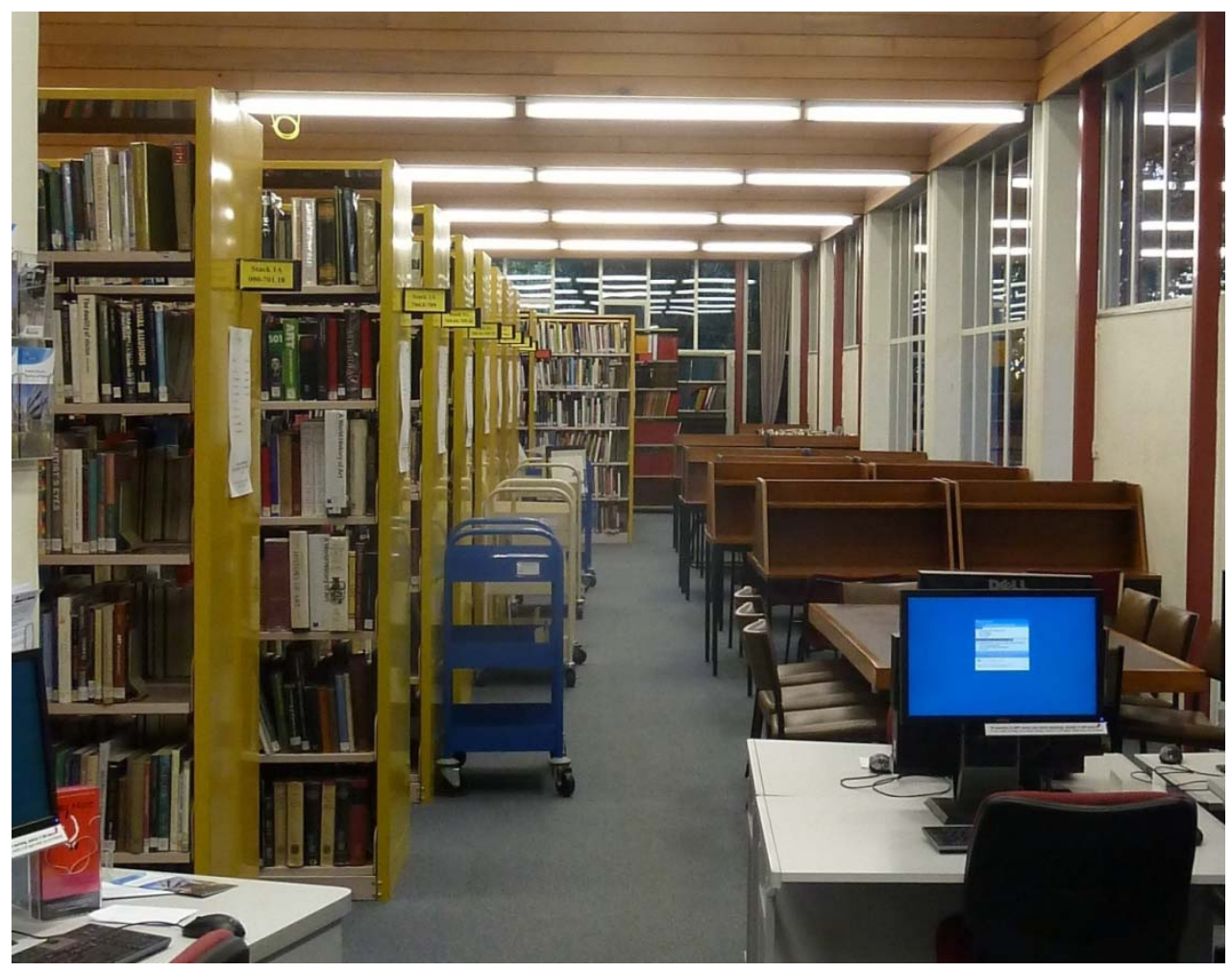

Figure 41. Fine Arts Library book stacks (2011) 


\section{Promotion}

Through collaboration and promotion the AUEL has made a concerted effort to bridge the divide between Whitaker Place, the main campus and the wider community (Bottorff, et al., 2008). The raising of the AUEL's profile outside of the University has been achieved through the availability of INZART from 2008, via a commercial database - Knowledge Basket (The University of Auckland Library, 2009). For institutional members only, the addition of 90,000 full-text historical press cuttings in INZART has also made this a value added resource (University of Auckland Library, 2010). These developments alongside the loading of the images from the AHID database onto the next generation Library Catalogue (The University of Auckland Library, 2010) has not only provided easier access to these resources but has generated internal promotional opportunities for the AUEL.

The emphasis on promotion and outreach has been paralleled in the AULS with the creation of the NICAI Libraries web log. The current Head of Elam, Jonathan Mane-Wheoki, has also championed the promotion of the School and its current and former staff and students. The Library has played a supporting role in these initiatives (Elam School of Fine Arts, 2010, July; Fine Arts Library, 2009, Spring, 2010, February; Passau, 2010, July, 2010, Summer, 2011, Autumn; Wolfe \& Elam School of Fine Arts, 2010)

While an official student exhibition calendar is no longer maintained, students continue to exhibit works in the Library. Artists’ books and installations have also been shown throughout the Library and in the carrels (Dunleavy, 2008; Harris, 2005). 


\section{Chapter Six: Future}

\section{Accommodation and Realignment}

The AUEL's accommodation will be an on-going issue at least for the medium term (J. Wild, personal communication, March 28, 2011). Due to financial and spatial constraints it is unlikely that the University would grant the building of a new Fine Arts Library as a singular entity. The amalgamation of the collection with another divisional or specialist library is the most viable option as argued by Crocket, "these new branch library iterations should...serve as the impetus to explore the future more aggressively than our bonds of tradition and inertia might otherwise allow” (2000, p. 192).

The Architecture and Planning Library would be the most appropriate candidate for amalgamation. The two libraries have complementary collections both in terms of items on the open shelf and in their respective special collections. There has been a strong formal and informal relationship between the two sites since the 1960s, therefore, an amalgamation of these two entities is a natural progression. An expansion of what could be described as a ‘NICAI Library Hub’ could be the inclusion of the Music and Dance Library and the NICAI Student Centre. The new Tamaki Library and Information Commons provides a blueprint for future possibilities. Richards' said in 1970 “Ideally, the collection should be within easy access for staff and students of the Departments of Fine Arts and Art History, which it serves” (1970c, p. 1). Therefore, if the Library was to be 'reconfigured' the location chosen would have to be an acceptable distance from its key stakeholders. 


\section{Change Management}

These physical and administrative changes would need to be well-managed with a robust change management plan in place (Fawcett, 1970). As suggested by Smith change management should be an ongoing focus:

Change and quality go hand-in-hand. Information providers and professionals operating in an environment of rapid and complex change should add to their managerial "toolkits" an understanding of the powerful interconnections between managing both organisational quality and organisational change - and a proactive approach to both. (I. Smith, p.127)

\section{Teaching}

The collaboration and pooling of knowledge and resources with other areas of the AULS will serve to enhance the teaching effectiveness of the AUEL. This could be achieved by:

- Targeted promotion of the generic library skills tutorials taught by the AULS Learning Services to Fine Arts and Art History students.

- The development of art related tutorials, focusing on the AUEL's collection and datasets, taught by the AUEL's Subject Librarians at the Learning Services facilities and included in their teaching calendar.

- The AUEL Subject Librarians to continue to design and deliver course and assignment specific tutorials that focus on critical analysis and support the course related assessment and learning outcomes. This programme requires the ongoing close collaboration with relevant academic staff. 


\section{Collection}

It is essential that The University of Auckland Library continue to support the different needs of their users through the acquisition and maintenance of their physical and electronic collections (Chad \& Miller, 2005; Cochrane, 2007; Ekman \& Quandt, 1995). In saying this, the AUEL no longer needs to provide an all-encompassing collection “we...can't be all things to all people. We have to say 'this is in our collection development plan’ and really line up behind that” (J. Wild, personal communication, March 28, 2011). The Library and its users might need to better utilise the collections in other Library's in the Auckland region to support niche areas of research (J. Wild, personal communication, March 28, 2011). In more populated countries (e.g. Britain and America) art libraries have long encouraged patrons to 'exploit' their proximity to other library collections by directing users to additional art resources (Brill, 1970). Brownson has also highlighted the complementarity of Auckland’s local collections (Brownson, 1988).

\section{Threats and Opportunities?}

The impact of Google and the increasing digitisation of books and images have been regarded as a threat to the relevancy and viability of libraries (Donovan, 2008). Henri, however, argued that art and architecture libraries will continue to be necessary "until the ability to visually browse the contents of our collections can be replicated from our user's desktops” (2003, p. 61).

Current trends in information technology have in fact provided an opportunity for libraries to shift their focus, allowing them to concentrate on the development and enhancement of 
their special collections. The possibilities for digital preservation of the AUEL's physical and electronic ephemera would provide better access to this dual format collection.

However, not everything can be made available online and the AUEL needs to have confidence in its identity or brand and in the exceptional physical services and resources it has to offer (Donovan, 2008). The exploration of potential archival opportunities in areas relating to fine arts and art history would be a positive development. The introduction of an archival software system will help in the re-description of the current archival collection making it more accessible for researchers. If these special collections and archives are to become more of a focus the Library's current accommodation for these resources will need to be re-assessed. 


\section{Conclusion}

This historical case study enabled the researcher to document the history of the AUEL and investigate the relationship the Library had with a number of institutional stakeholders over the past sixty years. This research was based on both archival resources and the completion of four semi-structured oral history interviews, supported by three written responses. The administrative documentation which made up the official account of the AUEL was elucidated and complemented by the counter narrative of the Library's former and current staff, involved in the oral history project. The oral histories injected a human element into this research and enabled the creation of a grand and a granular narrative.

The research suggests that the curricula of Elam and Art History have significantly influenced the development of the Library’s serial, book and special research collections and the Library's provision of a wide range of services. The establishment and ongoing creation of the AUEL's reference or special collections are also a characteristic of art libraries. Parallels have been drawn where possible to the developments and trends of specialist art libraries in the international context. The history of the AUEL in many instances mirrors the experiences of its overseas counterparts.

The AUEL's culture has on the whole been most influenced by its senior staff and its position as a specialist branch library. The research highlights the complexities of working within a decentralised library system. The culture of self-sufficiency and independence from the AU which characterised the AUEL until the late 1990s has shifted to being more collaborative as it has become more integrated into the AULS. However, the culture has always been defined by its commitment to supporting the needs and interests of the Library's core users, as evidenced in both the official documents and oral history 
narratives. Despite Elam and Art History experiencing a number of administrative and academic challenges these have not significantly impacted on the Library’s fundamental culture, which has been characterised by strong connections and positive collaborations between the staff and students.

Financial, staffing and accommodation issues have been a recurring theme in the shaping of the Library's history. From its small beginnings as a library / lunch room, staffed by the Elam office, the AUEL has become a well-resourced and well-used collection, staffed by trained librarians and practising artists. The staff, whose specialised knowledge and helpful and flexible approach to supporting the needs of their patrons, have created a welcoming and dynamic environment for their users. The AUEL, with its focus on the research and teaching needs of its users, is an integral part of the university experience for Elam and Art History students.

The past 60 years has seen the AUEL, as part of The University of Auckland, establish its place as the premier Fine Arts Library in New Zealand. The Library, its collection and its specialised staff are valued and respected, both within the University environment and the wider society, for the vital role they play in advancing the research, teaching, learning and creativity of the academic and arts community which they serve. 


\section{Opportunities for Further Research}

The scope of this historical research project was confined to the development of the Fine Arts Library. As a consequence a broader assessment of special Fine Art Libraries within New Zealand was not possible. Themes identified throughout this project as subjects for further research include:

- the historical development of New Zealand art libraries within both the tertiary and the museum and cultural heritage sectors.

- the establishment of and experiences in branch / divisional tertiary libraries within New Zealand.

- analysis of the differing needs of the fine art library users in the New Zealand context.

- investigation into the specialist professional development needs of fine art librarians in New Zealand. 


\section{Bibliography}

$£ 145,000$ arts school. (1960, September 14). New Zealand Herald.

Allan, D. (2008). A nation of readers : the lending library in Georgian England. London: British Library.

Art bibliographies. (1972). ARLIS Newsletter, 11, 20-22.

Art Libraries Society. (1974). A statement on standards in art and design libraries. ARLIS Newsletter, 14, 2-9.

Auckland Society of Arts, \& Fine Arts Committee. (1949, August 8). Notes of a meeting held on 8th August, in the Auckland University College Council room at which, in response to an invitation, the members of the council of the Society of Arts met the Fine Arts Committee. [Meeting Minutes]. (91-060, Drawer H). Elam Archive, Fine Arts Library, The University of Auckland, Auckland, N.Z.

Auckland University College. (1947, November 27). Memorandum of agreement with University College and Elam School board. [Memorandum]. (92-1008, Drawer F). Elam Archive, Fine Arts Library, The University of Auckland, Auckland, N.Z.

Auckland University College. (1952). Auckland University College report of the Librarian for the year 1952. Auckland, N.Z.: The University of Auckland Library.

AULSA Committee 1975/76. (1976, June). Laser, 3.

Aulton, J. (1970). City of Leicester Polytechnic Art Library. ARLIS Newsletter, 4, 5-6.

Baca, M., \& Tronzo, W. (2006). Art history and the digital world. Art Journal, 65(4), 5155. Retrieved from http://www.jstor.org

Baloghy, G. (1976). Elam. Craccum: Auckland University College Students' Paper, 50(17), 5.

Barrowman, R. (1995). The Turnbull : a library and its world. Auckland, N.Z.: Auckland University Press in association with the Historical Branch, Dept. of Internal Affairs. 
Basten, F. M. R. C. (2011). Narrating around. Journal of Management Development, 30(3), 260-269. doi: 10.1108/02621711111116180

Battles, M. (2003). Library : an unquiet history. New York: W.W. Norton.

Beadle, P. (1961, September 18). [Letter to Professor Simkin]. Fine Arts Library Archive, (Records up to 1962). Elam Archive, Fine Arts Library, The University of Auckland, Auckland, N.Z.

Beadle, P. (1962, May 1). [Memorandum to Mr J.A. Kirkness]. Fine Arts Library Archive, (Faculty Membership (Appointment to)). Elam Archive, Fine Arts Library, The University of Auckland, Auckland, N.Z.

Beadle, P. (1963). The University of Auckland Faculty of Fine Arts new building Director's report. Elam School of Fine Arts. The University of Auckland. Auckland, N.Z.

Beadle, P. (1964, April 9). [Memorandum for all staff members. and Mr. King]. Fine Arts Library Archive, (Faculty Membership (Appointment to)). Elam Archive, Fine Arts Library, The University of Auckland, Auckland, N.Z.

Beadle, P. (1965a, April 12). [Memorandum for the Registrar, The University of Auckland]. New buildings committee, (97-002, Box 3A). Elam Archive, Fine Arts Library, The University of Auckland, Auckland.

Beadle, P. (1965b, March 16). [Memorandum for the Registrar]. (97-037, Drawer I). Elam Archive, Fine Arts Library, The University of Auckland, Auckland, N.Z.

Beatson Rix-Trott Carter \& Co. (1972). New Library School of Fine Arts for the University of Auckland: Design Report. Auckland: The University of Auckland.

Beverley, S. (1989). Notis. Systems Newsletter(9), 2.

Big city buildings near completion. (1962, January 23). New Zealand Herald.

Binney, D. H. (1990). Elam after a century. Art New Zealand (56), 90-93.

Black, A. (1996). A new history of the English public library : social and intellectual contexts, 1850-1914. London: Leicester University Press. 
Black, A. (1997). Lost worlds of culture: Victorian libraries, library history and prospects for a history of information. Journal of Victorian Culture, 2(1), 95-112. doi:10.1080/13555509709505940

Black, A. (1998). Information and modernity: the history of information and the eclipse of library history. Library History, 14(May), 39-45.

Black, A. (2004). Every discipline needs a history : information management and the early information society in Britain. In W. B. Rayward (Ed.), Aware and responsible : papers of the 2001 Nordic-International Colloquium on Social and Cultural Awareness and Responsibility in Library, Information, and Documentation Studies (SCARLID) (pp. 29-47). Lanham, Md.: Scarecrow Press.

Black, A. (2006). Information history. Annual Review of Information Science and Technology, 40(1), 441-473. doi:10.1002/aris.1440400118

Black, A., \& Crawford, J. (2001). The identity of library and information history: An audit of library and information history. Library History, 17(2), 127.

Black, A., \& Hoare, P. (2006). Introduction: sources and methodologies for the history of libraries in the modern era The Cambridge history of libraries in Britain and Ireland. Vol. 3, 1850-2000 Cambridge: Cambridge University Press.

Blatz, P. K. (1990). Craftsmanship and flexibility in oral history: A pluralistic approach to methodology and theory. The Public Historian, 12(4), 7-22. Retrieved from http://www.jstor.org

Borgman, C. L. (2000). Digital libraries and the continuum of scholarly communication. Journal of Documentation, 56(4), 412 - 430. Retrieved from http://www.emeraldinsight.com

Bottorff, T., Glaser, R., Todd, A., \& Alderman, B. (2008). Branching out: Communication and collaboration among librarians at multi-campus institutions. Journal of Library Administration, 48(3), 329 - 363. doi:10.1080/01930820802289391

Brill, H. (1970). The Royal College of Art Library. ARLIS Newsletter, 3, 3-5.

Brown, G. H. (1965, February 24). [Letter to the Dean and Staff Elam School of Fine Arts]. (97-037, Drawer I). Elam Archive, Fine Arts Library, The University of Auckland, Auckland, N.Z. 
Brown, G. H. (1983). Interview by S. Franks. [Tape Recording]. (05-188). Elam Archive, Fine Arts Library, The University of Auckland, Auckland, N.Z.

Brown, G. H., \& Fine Arts Library. (1964). Elam School of Fine Arts Library rules 1964. Ephemera Files, (00-187, Ephemera File 1). Elam Archive, Fine Arts Library, The University of Auckland, Auckland, N.Z.

Brown, G. H., \& Keith, H. (1969). An introduction to New Zealand painting 1839-1967. London: Collins.

Brown, S., \& Swan, A. (2007). Researchers' use of academic libraries and their services: a report commissioned by the Research Information Network and the Consortium of Research Libraries: School of Electronics and Computer Science, University of Southampton.

Brownson, R. (1988). Four colour and full glossy : How do we service art reference? ARLIS/ANZ News, 26, 19-22.

Broxis, P. F. (1968). Organising the arts. London: Bingley.

Bryman, A. (2008). Social research methods. Oxford: Oxford University Press.

Bundy, A. L. (2004). Australian and New Zealand information literacy framework : principles, standards and practice. Adelaide Australian and New Zealand Institute for Information Literacy.

Cannon, C., \& Christie, P. (2005). Stock editing: creating guidelines for University of the Arts London. Art Libraries Journal, 30(2), 31-35.

Carr, D. (2007). Interlude: art information, arts learners: The role of libraries. In L. Bresler (Ed.), International Handbook of Research in Arts Education (pp. 721-727). doi:10.1007/978-1-4020-3052-9

Carrie, D. G., \& Mitchell, L. M. (2010). A Holistic Approach to Embedding Information Literacy in the Design, Delivery, and Assessment of an Undergraduate Business Program. In T. P. Mackey \& T. Jacobson (Eds.), Collaborative information literacy assessments : strategies for evaluating teaching and learning (pp. 25-52). New York: Neal-Schuman Publishers. 
Catt, R. (1951). They study in a dust heap. Craccum: Auckland University College Students' Paper, 25(7), 1, 4.

Chad, K., \& Miller, P. (2005). Do libraries matter? The rise of library 2.0. [White Paper]. Retrieved from http://www.talis.com/applications/downloads/white_papers/DoLibrariesMatter.pdf

Chamberlain, M. (2006). Narrative theory. In T. L. Charlton, L. E. Myers \& R. Sharpless (Eds.), Handbook of oral history (pp. 384-407). Lanham, Md.: Altamira Press.

Chiste, K. B., Glover, A., \& Westwood, G. (2000). Infiltration and entrenchment: capturing and securing information literacy territory in academe. The Journal of Academic Librarianship, 26(3), 202-208. doi:10.1016/s0099-1333(00)00101-4

Cochran, C. (1968). Elam School of Fine Arts : building report. Unpublished report (BArch), The University of Auckland, Auckland, N.Z.

Cochrane, L. S. (2007). If the academic library ceased to exist, would we have to invent it? EDUCAUSE Review, 42(1), 6-7.

Cocker, A. (2007). Universities driven to competitive malaise. New Zealand Herald. Retrieved from http://www.nzherald.co.nz/nz/news/article.cfm?c_id=1\&objectid=10467664

Cole, F. T. H., Armitage, G., Richards, V., \& Auckland University Library Staff Association. (1974). University libraries in education - what next?: a seminar arranged by the Auckland University Library Staff Association, April 20, 1974. Auckland, N.Z.: Auckland University Library Staff Association.

Coleman, M. D. (1973). Cultural ephemera in New Zealand libraries. New Zealand Libraries, 36(Special Issue), 196-201.

Colgan, W. (1980). The Governor's gift : the Auckland Public Library 1880-1980. Auckland, N.Z.: Richards Publishing and Auckland City Council.

Collins, K. (2003). Patrons, processes, and the profession -- Comparing the academic art library and the art museum library. Journal of Library Administration, 39(1), 77 89. 
Complete orders (1951-1960). [Acquisition records]. Fine Arts Library Archive. Elam Archive, Fine Arts Library, The University of Auckland, Auckland, N.Z.

Cooperative Committee on Library Building Plans., \& Burchard, J. E. (1949). Planning the university library building. Princeton: Princeton Univ. Press.

Copland, A. (2007, September 13). Freedom of expression New Zealand Herald, p. A20.

Copsey, J., \& The University of Auckland Library. (2011). Library perspectives a review of the current environment. Paper presented at the Library Perspectives, Conference Centre, The University of Auckland.

Craccum Reporter. (1963). Fine Arts for the masses. Craccum: Auckland University College Students' Paper, 28, 11.

Cracks appearing in the foundation. (2007, September 9). New Zealand Herald, pp. B4-B5.

Craig, S. (2003). Survey of current practices in art and architecture libraries. Journal of Library Administration, 39(1), 91-107. doi: 10.1300/J111v39n01_06

Crockett, C. (2000). Reconfiguring the branch library for a more virtual future. Library Administration \& Management 14(4), 191-196.

Cumming, G. L. (1958). School of Architecture Library. New Zealand Libraries, 21(7), 147-150.

Cumming, G. L. (1968). The University of Auckland School of Architecture Library bulletin for the year 1968. [Library Bulletin]. Fine Arts Library Archive. Elam Archive, Fine Arts Library, The University of Auckland, Auckland, N.Z.

Cummings, J. (1980). Art library design. ARLIS/ANZ News, 9, 10-18.

Daly-Peoples, J. (1990). Elam, 1890-1990. Auckland, N.Z: Elam School of Fine Arts.

Danto, E. A. (2008). Historical research. New York: Oxford University Press.

Davis, A. (1969). Some problems in art librarianship: Recommended ARLIS policy on subcommittee structure. ARLIS Newsletter, 1 \& 2, 7-12. 
Davis, D. G. (2010). International trends in library history. Libraries \& the Cultural Record, 45(1), 123-129. doi: 10.1353/lac.0.0110

Davis, D. G., \& Aho, J. A. (2001). Wither library history? A critical essay on Black's model for the future of library history. Library History, 17(1), 21.

Department of Art History, \& Green, A. S. G. (1972, May 19). Department of Art History request for additional finance for books for art history for 1973. Fine Arts Library Archive. Elam Archive, Fine Arts Library, The University of Auckland, Auckland, N.Z.

Desiderius, O. (1975). What is art all about? Sydney: Hicks, Smith \& Sons.

Dewald, N., Scholz-Crane, A., Booth, A., \& Levine, C. (2000). Information literacy at a distance: instructional design issues. The Journal of Academic Librarianship, 26(1), 33-44. doi:10.1016/s0099-1333(99)00121-4

Dirst, T. L. (2003). Improving art history education: Library and faculty partnerships in instructional technology development. Information Technology and Libraries, 22(2), 83.

Donovan, J. M. (2008). Skating on thin intermediation: Can libraries survive? Legal Reference Services Quarterly, 27(2), 95 - 116. doi:10.1080/02703190802398581

Droysen, J. G. (1893). Outline of the principles of history (T. Elisha Benjamin Andrews, Trans.). Boston: Ginn \& Company.

Dunleavy, R. (2008). [Future books]. Auckland, N.Z.: Elam School of Fine Arts.

Durey, P. (1970, September 24). [Letter to Fine Arts Library]. Fine Arts Library Archive, (Equipment to 1977 (Closed)). Elam Archive, Fine Arts Library, The University of Auckland, Auckland, N.Z.

Durey, P. (1976a, March 17). Furnishing grant application : Fine Arts Library extension. Fine Arts Library Archive, (Equipment to 1977 (Closed)). Elam Archive, Fine Arts Library, The University of Auckland, Auckland, N.Z.

Durey, P. (1976b). Library news: Fine Arts Library extension. University of Auckland News, 6(8), 28-29. 
Durey, P. (1977). Library news: Fine Arts Library extension. University of Auckland News, 7(2), 26.

Durey, P. (1984). Question time. Systems Newsletter(3), 1.

Education Department, \& Elam School of Fine Arts. (c.1949). New Zealand Education Department annual returns of buildings and sites. (92-1008, Drawer F). Elam Archive, Fine Arts Library, The University of Auckland, Auckland, N.Z.

Education Department, \& McMurtrie, A. F. (1948, October 11). [Letter to the Registrar, Auckland University College]. (92-1008, Drawer F). Elam Archive, Fine Arts Library, The University of Auckland, Auckland, N.Z.

Edwards, J. (1997). In loving memory of the catalogue. Auckland, N.Z.: J. Edwards.

Ekman, R. H., \& Quandt, R. E. (1995). Scholarly communication, academic libraries, and technology. Change, 27(1), 34-44. Retrieved from http://www.jstor.org

Elam. (1972). Craccum, 46(3), 11.

Elam School of Fine Arts. (1963). Home \& building, 26(3), 60-61, 25.

Elam School of Fine Arts. (1950, November 27). Meeting of the Elam School of Fine Arts Board. [Meeting Minutes]. (91-016, Drawer G). Elam Archive, Fine Arts Library, The University of Auckland, Auckland, N.Z.

Elam School of Fine Arts. (1966, March 22). University of Auckland, Elam School of Fine Arts interim library committee. [Minutes]. Minutes all committees Febuary 1961October 1966, (97-010). Elam Archive, Fine Arts Library, The University of Auckland, Auckland.

Elam School of Fine Arts. (1970). Minutes of meeting of Faculty held, Thursday, 16 July 1970. [Minute Book]. Elam School of Fine Arts Faculty minutes 1970-1987, (97010, Box). Elam Archive, Fine Arts Library, The University of Auckland, Auckland, N.Z.

Elam School of Fine Arts. (1976). School of Fine Arts University of Auckland 1977. [Prospectus]. (92-023, Box). Elam Archive, Fine Arts Library, The University of Auckland, Auckland, N.Z. 
Elam School of Fine Arts. (1983). Elam 1950-1983 : an Auckland University centenary exhibition, Auckland City Art Gallery, 26 August to 25 September 1983. Auckland, N.Z.: Elam School of Fine Arts.

Elam School of Fine Arts. (2010, July). Rock on: Elam celebrates 60 years with The University of Auckland. Elam e-news. Retrieved from http://ndhawiki.natlib.govt.nz/ndha

Elam School of Fine Arts. (c.1970-1989). Post-object art files, (Elam MSS\&A 2010/1). Fine Arts Library Special Collections MSS \& Archives, The University of Auckland, Auckand.

Elam stirs: students expresss disatisfaction. (1972). Craccum, 46(23), 6-7.

Ellis, C. G. S. (1953, March 19). [Letter to the Registrar, Auckland University College]. Fine Arts Library Archive, (Records up to 1962). Elam Archive, Fine Arts Library, The University of Auckland, Auckland, N.Z.

Ellis, C. G. S. (1965, April 28). [Letter to Mr Beatson, Beaston, Rix-Trott, Carter \& Co.,]. New buildings committee, (97-002, Box 3A). Elam Archive, Fine Arts Library, The University of Auckland, Auckland.

Ellis, R. (1963). Notes. New buildings committee, (97-002, Box 3A). Elam Archive, Fine Arts Library, The University of Auckland, Auckland.

Ellis, R. (1969, July 11). [Memorandum to Colin McCahon, Tom Hutchins, Jim Allen]. (97-002, Drawer G). Elam Archive, Fine Arts Library, The University of Auckland, Auckland, N.Z.

Ellis, R., \& Tapper, G. (c.1983). Interview by Barbi de Lange. [Tape Recording]. (05-188). Elam Archive, Fine Arts Library, The University of Auckland, Auckland, N.Z.

Fairburn, A. R. D. (1944-1945). The Auckland School of Art. Arts in New Zealand, 17(1), 21-32.

Fairburn, A. R. D. (1945). Arts and crafts in schools: A view of aesthetic education. Arts in New Zealand 17(3), 9-12, 32-36. 
Fairburn, A. R. D. (1955). Control of the Auckland City Art Gallery. [Report]. (92-029, Drawer H). Elam Archive, Fine Arts Library, The University of Auckland, Auckland, N.Z.

Fawcett, T. (1970). Proposal for a co-operative acquisitions scheme for art literature. ARLIS Newsletter, 4, 2.

Fawcett, T. (1975). The compleat art librarian, or what it takes. ARLIS Newsletter, 22, 7-9.

Fine Arts Librarian. (1976). University of Auckland Library: Report of the Fine Arts Librarian for the year 1975. [Report]. (06-319, Drawer K). Elam Archive, Fine Arts Library, The University of Auckland, Auckland.

Fine Arts Librarian. (1977). University of Auckland Library: Report of the Fine Arts Librarian for the year ended 31 December 1976. [Report]. (06-319, Drawer K). Elam Archive, Fine Arts Library, The University of Auckland, Auckland.

Fine Arts Librarian. (1979, January 20). University of Auckland Library: Report of the Fine Arts Librarian for the year ended 31 December 1978. [Report]. (06-319, Drawer K). Elam Archive, Fine Arts Library, The University of Auckland, Auckland.

Fine Arts Library. (1965, September). Library: Proposed requirements for a LIBRARY WORKROOM. Fine Arts Library Archive. Elam Archive, Fine Arts Library, The University of Auckland, Auckland, N.Z.

Fine Arts Library. (1970). University of Auckland Library: Report of the Fine Arts Librarian for the year ended 31 December 1969. Auckland, N.Z.: The University of Auckland.

Fine Arts Library. (1971). University of Auckland Library: Report of the Fine Arts Librarian for the year ended 31st December 1970. Auckland, N.Z.: The University of Auckland.

Fine Arts Library. (1972). University of Auckland Library: Report of the Fine Arts Librarian for the year ended 31st December 1971. Auckland, N.Z.: The University of Auckland.

Fine Arts Library. (1973). University of Auckland Library: Report of the Fine Arts Librarian for the year ended 31st December 1972. Auckland, N.Z.: The University of Auckland. 
Fine Arts Library. (1974). Gifts of the Elam Trust over the years 1967 -. [Correspondence]. Fine Arts Library Archive, (Gifts). Elam Archive, Fine Arts Library, The University of Auckland, Auckland, N.Z.

Fine Arts Library. (1975). University of Auckland Library: Report of the Fine Arts Librarian for the year ended 31st December 1974. Auckland, N.Z.: The University of Auckland.

Fine Arts Library. (1976). University of Auckland Library: Report of the Fine Arts Librarian for the year ended 31st December 1975. Auckland, N.Z.: The University of Auckland.

Fine Arts Library. (1980). University of Auckland Library: Report of the Fine Arts Librarian for the year ended 31 December 1979. Auckland, N.Z.: The University of Auckland.

Fine Arts Library. (1981). University of Auckland Library: Report of the Fine Arts Librarian for the year ended 31 December 1980. Auckland, N.Z.: The University of Auckland.

Fine Arts Library. (1982). University of Auckland Library: Report of the Fine Arts Librarian for the year ended 31 December 1981. Auckland, N.Z.: The University of Auckland.

Fine Arts Library. (1983). University of Auckland Library: Report of the Fine Arts Librarian for the year ended 31 December 1982. Auckland, N.Z.: The University of Auckland.

Fine Arts Library. (1985). University of Auckland Library: Report of the Fine Arts Librarian for the year ended 31 December 1984. Auckland, N.Z.: The University of Auckland.

Fine Arts Library. (1986). University of Auckland Library: Report of the Fine Arts Librarian for the year ended 31 December 1985. Auckland, N.Z.: The University of Auckland.

Fine Arts Library. (1987). University of Auckland Library: Report of the Fine Arts Librarian for the year ended 31 December 1986. Auckland, N.Z.: The University of Auckland. 
Fine Arts Library. (1989). University of Auckland Library: Report of the Fine Arts Librarian for the year ended 31 December 1988. Auckland, N.Z.: The University of Auckland.

Fine Arts Library. (2009, Spring). Fine Arts Library. Elam e-news. Retrieved from http://ndha-wiki.natlib.govt.nz/ndha

Fine Arts Library. (2010, February). Fine Arts Library | Te Herenga Toi. Elam e-news. Retrieved from http://ndha-wiki.natlib.govt.nz/ndha

Fine Arts Library, \& Richards, V. (1965). Fine Arts Library Bulletin, 1.

Fine Arts Library, \& Richards, V. (1968). Fine Arts Library Bulletin, 10.

Fine Arts Library, \& Richards, V. (1977). Fine Arts Library Bulletin, 37.

Fine Arts Library, \& Wild, J. (2008, July). Collection development policy - Fine Arts Library Retrieved March 10, 2010, from http://www.library.auckland.ac.nz/about/biblio/cdp/cdpart.htm

Fine Arts Library Sub-Committee. (1952, August 12). Minutes of the meeting of the Fine Arts sub-committee. Fine Arts Library Sub-Committee, (91-058, Drawer H). Elam Archive, Fine Arts Library, The University of Auckland, Auckland, N.Z.

Fine Arts Library Sub-Committee. (1954, March 18). Elam School of Fine Arts financial statement. Fine Arts Library Sub-Committee, (91-058, Drawer H). Elam Archive, Fine Arts Library, The University of Auckland, Auckland, N.Z.

Fine Arts Library Sub-Committee. (1956, March 26). Minutes of the meeting of the Fine Arts sub-committee. Fine Arts Library Sub-Committee, (91-058, Drawer H). Elam Archive, Fine Arts Library, The University of Auckland, Auckland, N.Z.

Fine Arts Library Sub-Committee. (1957, October 23). Minutes of the meeting of the Fine Arts sub-committee. Fine Arts Library Sub-Committee, (91-058, Drawer H). Elam Archive, Fine Arts Library, The University of Auckland, Auckland, N.Z.

Fine Arts Library Sub-Committee. (1960, July 25). Minutes of the meeting of the Fine Arts sub-committee. Fine Arts Library Sub-Committee, (91-058, Drawer H). Elam Archive, Fine Arts Library, The University of Auckland, Auckland, N.Z. 
Fine Arts Library Sub-Committee. (1962, February 14). Minutes of the meeting of the Fine Arts sub-committee. [Minutes]. Fine Arts Library Sub-Committee, (91-058, Drawer H). Elam Archive, Fine Arts Library, The University of Auckland, Auckland, N.Z.

Fisher, A. (1951, November 28). [Letter to Mr Sandall]. Fine Arts Library Archive, (Records up to 1962). Elam Archive, Fine Arts Library, The University of Auckland, Auckland, N.Z.

Fisher, A. (1955, September). Report on Elam School of Fine Arts. (91-019, Drawer G). Elam Archive, Fine Arts Library, The University of Auckland, Auckland, N.Z.

Fisher, A. (1958). Elam School of Fine Arts : The University of Auckland. [Report]. (91025, Drawer G). Elam Archive, Fine Art Library, The University of Auckland, Auckland, N.Z.

Frank, P. (1999). Student artists in the library: an investigation of how they use general academic libraries for their creative needs. The Journal of Academic Librarianship, 25(6), 445-455.

Franks, S. A. (1984). Elam 1890-1983 a history of the Elam School of Fine Arts, University of Auckland (Unpublished master's thesis), The University of Auckland, Auckland, N.Z.

Fussler, H. H. (1947). Library buildings for library service. Chicago: American Library Association.

García, A., \& Coso, T. (2006). The new hybrid art library: printed materials and virtual information. Collection Building, 25(3), 78-84. doi: 10.1108/01604950610677549

Gay, C. (1968). Eighteenth century painting. New York: Funk \& Wagnalls.

Genoni, P., Merrick, H., \& Willson, M. A. (2006). Scholarly communities, e-research literacy and the academic librarian. The Electronic Library, 24(6), 734 - 746. doi:10.1108/02640470610714189

Goldman, P. (1994). Searching for history in organizational theory: Comment on Kieser. Organization Science, 5(4), 621-623. 
Goodwin, J., \& O'Connor, H. (2006). Contextualising the research process: using interviewer notes in the secondary analysis of qualitative data. The Qualitative Report, 11(2), 374-392. Retrieved from http://www.nova.edu/ssss/QR/

Gorman, G. E. (2005). Qualitative research for the information professional : a practical handbook. London: Facet.

Govender, S. (2005). The art of collaboration and networking between two art libraries. ARLIS/ANZ Journal: journal of the Arts Libraries Society Australia and New Zealand, 60, 51-53.

Green, A. S. G. (1975a, February 13). [Letter to V. Richards]. Fine Arts Library Archive, (Library Memo Closed 1979). Elam Archive, Fine Arts Library, The University of Auckland, Auckland, N.Z.

Green, A. S. G. (1975b, August 18). Department of Art History [Correspondence]. (97-002, Box 5). Elam Archive, Fine Arts Library, The University of Auckland, Auckland, N.Z.

Grunwell, R. (2006, June 4). 'Hush money' paid to sacked art school staff Sunday star times, p. News 6.

Guba, E. G., \& Lincoln, Y. S. (1994). Competing paradigms in qualitative research. In N. K. Denzin \& Y. S. Lincoln (Eds.), Handbook of qualitative research (pp. 105-117). Thousand Oaks, CA: Sage.

Hardesty, L. (1995). Faculty culture and bibliographic instruction: an exploratory analysis. Library Trends, 44(2), 339-367.

Harris, A. (2005). [After hours]. Auckland, N.Z.: A. Harris.

Harrison, K. C. (1994). Why library history? Library Review, 43(8), 9-13.

Haynes, K. (2010). Other lives in accounting: Critical reflections on oral history methodology in action. Critical Perspectives on Accounting, 21(3), 221-231. doi: 10.1016/j.cpa.2009.11.002

Heath, F. (2006). Transforming research libraries: Teaching and learning in the digital age. [Speech]. Art Documentation: Bulletin of the Art Libraries Society of North America, 25, 4-12. 
Heaton, J. (1998). Secondary analysis of qualitative data. Social Research Update, 22. Retrieved from http://sru.soc.surrey.ac.uk/SRU22.html

Heavy loss in fire. (1949). New Zealand Herald, A6.

Hemmig, W. S. (2008). The information-seeking behavior of visual artists: a literature review. Journal of Documentation, 64(3), 343.

Henri, J. J. (2003). Management, public service, and access Issues: Serving special collections in an architecture branch library. [Article]. Journal of Library Administration, 39(1), 57-76.

Hildenbrand, S. (2000). Library feminism and library women's history: Activism and scholarship, equity and culture. Libraries \& Culture, 35(1), 51-65.

Hoare, P., Leedham-Green, E. S., Webber, T., Mandelbrote, G., Manley, K. A., \& Black, A. (2006). The Cambridge history of libraries in Britain and Ireland. Vol. 3, 1850 2000 Cambridge, UK: Cambridge University Press.

Hunter, E. (2006). Automating the library process. In A. Black \& P. Hoare (Eds.), The Cambridge history of libraries in Britain and Ireland. Vol. 3, 1850-2000 Cambridge: Cambridge University Press.

Hyde, M. J. (1980). Philosophical hermeneutics and the communicative experience: The paradigm of oral history. Man and World, 13(1), 81-98. doi: 10.1007/bf01271616

Inch Art. (1976). Craccum, 50(1), Supplement.

Irwin, T. (2008/2009). In for a penny, in for a pound: the revitalisation and redevelopment of two in-house indexes ARLIS/ANZ Journal: journal of the Arts Libraries Society Australia and New Zealand, 65, 11-14.

Jackson, N. (2006). The art of preserving ephemera ARLIS / ANZ journal, 62, 26-31.

Jenkins, P. O. (2005). Faculty-librarian relationships (First ed.). Oxford: Chandos Publishing.

Johnson, O. A. (1988). The true university : a short history of the University of Auckland Library, 1883-1986. Auckland, N.Z.: Auckland University Library. 
Jurkowski, O. L. (1997). Big fish in a little pond: Autonomy in an academic branch library. Illinois Libraries, 79(4). Retrieved from http://www.lib.niu.edu

Keefe, G. (1988). Artists’ books. New Zealand Libraries, 45(11), 259-262.

Keefe, G. (1993). Fine Arts Library. Elam Office, (08-055, Box EO1). Elam Archive, Fine Arts Library, The University of Auckland, Auckland, N.Z.

Kennedy, J. R. (1970). Integrated library instruction Library Journal, 15, 1451-1453.

Kieser, A. (1994). Why organization theory needs historical analyses: And how this should be performed. Organization Science, 5(4), 608-620.

Kirkness, J. A. (1963, November). Applicants are invited for the application of librarianin-charge Elam School of Fine Arts: Conditions of employment. (97-037, Drawer I). Elam Archive, Fine Arts Library, The University of Auckland, Auckland, N.Z.

Kobzina, N. G. (2010). A faculty - librarian partnership: A unique opportunity for course integration. Journal of Library Administration, 50(4), 293-314.

Langmead, S., \& Beckman, M. (1970). New library design; guide lines to planning academic library buildings. Toronto: J. Wiley and Sons Canada.

Lawrence, A. M. (1965). Elam School of Fine Arts The University of Auckland. ART and Australia, 2(4), 288-290.

Layne, S. S. (1994). Artists, art historians, and visual art information. The Reference Librarian, 22(47), 23-36. doi: 10.1300/J120v22n47_03

Leja, I. (2006). No closed books, no closed doors, and no closed minds: A history of the Nova Scotia College of Art and Design (NSCAD University) Library. In ARLIS/Canada (Ed.), Essays in the history of art librarianship in Canada (pp. 140142). Ottawa: ARLIS/Canada. Retrieved from http://www.arliscanada.ca/hal/Arlis\%20online_28_06_06.pdf

Lerner, F. A. (2001). The story of libraries : from the invention of writing to the computer age. New York: Continuum. 
Library - Elam. (1963). (97-002 Box 3). Elam Archive, Fine Arts Library, The University of Auckland, Auckland, N.Z.

Line, M. B. (1991). Library management styles and structures: a need to rethink? Journal of Librarianship and Information Science, 23(2), 97-104. doi: 10.1177/096100069102300205

Lockwood, V. (1966a). Elam School of Fine Arts Library proposed extensions 1966-1967. [Drawing]. Fine Arts Library Archive, (Library Plans 1963-1974). Elam Archive, Fine Arts Library, The University of Auckland, Auckland, N.Z.

Lockwood, V. (1966b). Library Extensions. (91-002, Drawer G). Elam Archive, Fine Arts Library, The University of Auckland, Auckland.

Lockwood, V. (1967, January 24). re Library Usage 1967. [Correspondence]. Fine Arts Library Archive, (Faculty). Elam Archive, Fine Arts Library, The University of Auckland, Auckland, N.Z.

Macpherson, R. (1999a). The methodology of a minor miracle: killing a myth through strategic planning in the Elam School of Fine Arts. International Journal of Educational Management, 13, 272-280.

Macpherson, R. (1999b). An organised anarchy or a community of diverse virtue ethics? The case of the Elam School of Fine Arts. International Journal of Educational Management, 13(5), 219 - 226.

Mason, H., \& Robinson, L. (2011). The information-related behaviour of emerging artists and designers: Inspiration and guidance for new practitioners. Journal of Documentation, 67(1), 159-180. doi: 10.1108/00220411111105498

McCahon, C. (1976). [Letter to Valerie Richards]. Fine Arts Library Archive, (Gifts). Elam Archive, Fine Arts Library, The University of Auckland, Auckland, N.Z.

McEldowney, W. J. (2006). Geoffrey Alley, librarian : his life and work. Wellington, N.Z.: Victoria University Press.

McKeon, B. (2001). Libraries. In P. Griffith, D. R. Harvey, K. I. D. Maslen \& R. Somerville (Eds.), Book and print in New Zealand: a guide to print culture in Aotearoa (pp. 168-196). Wellington, N.Z.: New Zealand Electronic Text Centre. 
McLaren, C. (1972). Paint, not print. Elam seed, 2, 3.

Mercer, A. E. (1953). What about premises? A talk on the library building situation. New Zealand Libraries, 16(1), 1-6.

Mercier, J. (1994). Looking at organizational culture, hermeneutically. Administration \& Society, 26(1), 28-47.

Miller, W., \& Pellen, R. M. (2004). Libraries within their institutions : creative collaborations. Binghamton, NY: Haworth Information Press.

Murray, P. (1975). Some problems of an art historian in a library. ARLIS Newsletter, 23, 47.

Neal, K. W. (1973). British academic libraries. Wilmslow, Cheshire: K.W. Neal.

New School of Fine Arts. (1960, September 9). The Auckland Star, p. Tenders 17

New Zealand Library Association. (1949). Elementary principles of library planning. New Zealand Libraries, 12, 245-247.

New Zealand. Committee on New Zealand Universities, \& Parry, D. H. (1960). Report of the Committee on New Zealand Universities, December, 1959. Wellington: Govt. Print.

News from departments. (1975). University of Auckland News, 5(4), 26.

Nuttall, M. (1984). The Library's own computer. Systems Newsletter(1), 1-2.

Officers for 1977 and their special responsibilities. (1977, July). Laser, n.p.

Olle, J. G. H. (1979). Library history London: C. Bingley ; K.G. Saur.

Pacey, P. (1980a). Correspondence to ARLIS / ANZ. ARLIS/ANZ News, 8, 2-3.

Pacey, P. (1980b). Ephemera and art libraries. ARLIS/ANZ News, 9, 29-39. 
Pacey, P. (1980c). VIVA LA DIFFERENCE! the uniqueness of art libraries. ARLIS/ANZ News, 8, 10-17.

Pacey, P. (1982). How art students use libraries - if they do. Art Libraries Journal, 7(1), 3338.

Passau, V. (2010, July). Fine Arts Library. Elam e-news. Retrieved from http://ndhawiki.natlib.govt.nz/ndha

Passau, V. (2010, Summer). Elam Fine Arts Library. Elam e-news. Retrieved from http://ndha-wiki.natlib.govt.nz/ndha

Passau, V. (2011, Autumn). Elam Fine Arts Library. Elam e-news. Retrieved from http://ndha-wiki.natlib.govt.nz/ndha

Passau, V., \& Fine Arts Library. (2009, July 22). Inventory of the Beverley Simmons collection [Web log post]. Retrieved from http://blogs.library.auckland.ac.nz/nicai/archive/2009/07/22/Inventory-of-theBeverley-Simmons-Collection.aspx

Passau, V., \& Fine Arts Library. (2010a, August 27). New Zealand Illustrators collection [Web log post]. Retrieved from http://blogs.library.auckland.ac.nz/nicai/archive/2010/08/27/New-ZealandIllustrators-Collection.aspx

Passau, V., \& Fine Arts Library. (2010b, June 29). Post-Object art files [Web log post]. Retrieved from http://blogs.library.auckland.ac.nz/nicai/archive/2010/06/29/PostObject-Art-Files.aspx

Peake, D. G. (1981). Library automation in Australia: the state of the art. [Article]. Program: Electronic Library \& Information Systems, 15, 11-23.

Phillpot, C., \& Doran, M. (1970). Chelsea School of Art - An art school library classification. ARLIS Newsletter, 5, 2-5.

Pickard, A. J. (2007). Research methods in information. London: Facet.

Polastron, L. X. (2007). Books on fire : the tumultuous story of the world's great libraries. London: Thames \& Hudson. 
Pollard, N. (1977). Arty choke: acquisitions and ephemera. Art Libraries Journal, 2(4), 415.

Pollard, N. (1978). Printed ephemera. In P. Pacey (Ed.), Art library manual : a guide to resources and practice (pp. 316-334). London: Bowker.

Ponterotto, J. G. (2005). Qualitative research in counseling psychology: A primer on research paradigms and philosophy of science. Journal of Counseling Psychology, 52(2), 126-136.

Porter, K. I., \& Richards, V. (1990). Library: Farewell to Fine Arts Librarian. University of Auckland News.

Preston, A. (2001). Book selling. In P. Griffith, D. R. Harvey, K. I. D. Maslen \& R. Somerville (Eds.), Book and print in New Zealand: a guide to print culture in Aotearoa (pp. 157-166). Wellington, N.Z.: New Zealand Electronic Text Centre.

Pritchard, P. A. (2010). The embedded science librarian: Partner in curriculum design and delivery. Journal of Library Administration, 50(4), 373 - 396.

Ramsden, M. J., \& Harrop, D. A. (1970). General problems of classification in art libraries. ARLIS Newsletter, 6, 7-8.

Registrar Auckland University College. (1952, November 20). [Letter to the Director of Education, Education Department]. Fine Arts Library Archive, (Records up to 1962). Elam Archive, Fine Arts Library, The University of Auckland, Auckland, N.Z.

Richards, V. (1969, April 1). [Letter to Fletcher Industries]. Fine Arts Library Archive, (Gifts). Elam Archive, Fine Arts Library, The University of Auckland, Auckland, N.Z.

Richards, V. (1970a, October 20). [Letter to Gordon H. Brown]. Fine Arts Library Archive, (G-H File). Elam Archive, Fine Arts Library, The University of Auckland, Auckland, N.Z.

Richards, V. (1970b, April 8). Report on accommodation - Fine Arts Library. [Memorandum]. Fine Arts Library Archive, (Library Plans 1963-1974). Elam Archive, Fine Arts Library, The University of Auckland, Auckland, Auckland, N.Z. 
Richards, V. (1970c, September 23). University of Auckland, Fine Arts Library : Future accomodation requirements for estimated on a fifteen year growth pattern to 1985. [Report]. Fine Arts Library Archive, (Equipment to 1977 (Closed)). Elam Archive, Fine Arts Library, The University of Auckland, Auckland, N.Z.

Richards, V. (1972a). Fine Arts Library Bulletin, 24.

Richards, V. (1972b). Fine Arts Library Bulletin, 23.

Richards, V. (1973a). Laser(1), 3.

Richards, V. (1973b). Fine Arts Library extensions - 1973. [Drawing]. Fine Arts Library Archive, (Library Plans 1963-1974). Elam Archive, Fine Arts Library, The University of Auckland, Auckland, N.Z.

Richards, V. (1974, January 29). [Letter to the Elam Trust]. Fine Arts Library Archive, (Gifts). Elam Archive, Fine Arts Library, The University of Auckland, Auckland, N.Z.

Richards, V. (1975a). ACTION - a report on AULSA Committee's activities so far. Laser(6), n.p.

Richards, V. (1975b). The continuing report from the sub-committee on N.Z.L.A. certificate holders and trainees. Laser(5), n.p.

Richards, V. (1975c, October 8). The Fine Arts Library will be OPEN for the following hours during the 1975 examination period. [Memo]. Fine Arts Library Archive, (Library Memo Closed - 1979). Elam Archive, Fine Arts Library, The University of Auckland, Auckland, N.Z.

Richards, V. (1975d). A report on the United Women's Convention. Laser(7), 7-9.

Richards, V. (1976, July 27). [Letter to Peter Tomory]. Fine Arts Library Archive, (ARLIS / ANZ). Elam Archive, Fine Arts Library, The University of Auckland, Auckland, N.Z.

Richards, V. (1979, March 23). Estimates 1979: Additional staff and equipment. [Memo]. Fine Arts Library Archive, (Library Memo closed 1979). Elam Archive, Fine Arts Library, The University of Auckland, Auckland, N.Z. 
Richards, V. (1981, June 11). [Letter to Joan Comer]. Fine Arts Library Archive, (G-H File). Elam Archive, Fine Arts Library, The University of Auckland, Auckland, N.Z.

Richards, V. (1982). Art Libraries in New Zealand. ARLIS/ANZ News, 12, 9-10.

Richards, V. (1983a, May 25). Interview by Simon Franks. [Tape Recording]. (05-188). Elam Archive, Fine Arts Library, The University of Auckland, Auckland, N.Z.

Richards, V. (1983b). Report of the Fine Arts Librarian for the year ended 31 December 1982. Auckland: The University of Auckland Library.

Richards, V. (1984). Report of the Fine Arts Librarian for the year ended 31 December 1983. Auckland: The University of Auckland Library.

Richards, V. (1986a). ARLIS/ANZ and art libraries in the Antipodes. Art Libraries Journal, 11(1), 12-16.

Richards, V. (1986b, March 12). Report on staffing, Fine Arts Library. [Memorandum]. Fine Arts Library Archive, (AUEL Staff 1985-1987 Closed). Elam Archive, Fine Arts Library, The University of Auckland, Auckland, N.Z.

Richards, V. (1990). University of Auckland Library: Report of the Fine Arts Librarian for the year ended 31 December 1989. Auckland: The University of Auckland.

Robertson, J. K. (1968). Automation in new zealand libraries. New Zealand Libraries, 31, 98-100.

Ronnie, M. A. (1993). Books to the people : a history of regional library services in New Zealand. Wellington, N.Z.: New Zealand Library Association in conjunction with Ancora Press, Graduate Dept. of Librarianship, Archives and Records, Monash University.

Ronnie, M. A. (2008). Freedom to read : a centennial history of Dunedin Public Library. Dunedin, N.Z.: Dunedin Public Libraries \& The Dunedin Public Library Association.

Rowan, J. (1999). A history of the first two University of Auckland Librarians, Alice E. Minchin, 1918-1945 and Fredrick Arthur Sandall 1946-1969. Master of Library and Information Studies, Victoria University of Wellington, Wellington. 
Rusbridge, C. (1998, October 2, 2009). Towards the hybrid library D-Lib Magazine July / August. Retrieved 1 April, 2010, from http://www.dlib.org/dlib/july98/rusbridge/07rusbridge.html

Sammon, C. E. (2006). The Alberta College of Art + Design : Luke Lindoe Library. In ARLIS/Canada (Ed.), Essays in the history of art librarianship in Canada (pp. 98100). Ottawa: ARLIS/Canada. Retrieved from http://www.arliscanada.ca/hal/Arlis\%20online_28_06_06.pdf

Sandall, F. A. (1950a, August 16). [Letter to Miss Cassels]. Fine Arts Library Archive. Elam Archive, Fine Arts Library, The University of Auckland, Auckland, N.Z.

Sandall, F. A. (1950b, February 28). [Letter to Mr Fisher]. Fine Arts Library Archive, (Records up to 1962). Elam Archive, Fine Arts Library, The University of Auckland, Auckland, N.Z.

Sandall, F. A. (1951, November 7). [Letter to the Registrar]. Fine Arts Library Archive, (Records up to 1962). Elam Archive, Fine Arts Library, The University of Auckland, Auckland, N.Z.

Sandall, F. A. (1952, August 12). Survey of University and similar libraries. [Memorandum for the Registrar]. The University of Auckland Library, Auckland, N.Z.

Sandall, F. A. (1956). Auckland University College Library: Report of the Librarian on refresher leave 1956. Records relating to library building, (MSS \& Archives Vault 31 ). General Library Special Collections, The University of Auckland, Auckland

Sandall, F. A. (1961, October 9). [Memorandum to Professor Simkin]. Fine Arts Library Archive, (Faculty). Elam Archive, Fine Arts Library, The University of Auckland, Auckland, N.Z.

Sandall, F. A. (1963, February 1). Departmental property and the use of the word "Librarian". [Memorandum to Heads of Departments]. Fine Arts Library Archive, (Faculty Membership (Appointment to)). Elam Archive, Fine Arts Library, The University of Auckland, Auckland, N.Z.

Saunders, J. (1975, September 11). [Letter to A.S.G. Green]. (97-002, Box 5). Elam Archive, Fine Arts Library, The University of Auckland, Auckland, N.Z.

Saunders, J. (1983). Interview by Simon Franks. [Tape Recording]. (05-188). Elam Archive, Fine Arts Library, The University of Auckland, Auckland, N.Z. 
Schein, E. H. (1991). The role of the founder in the creation of organizational culture. In P. J. Frost (Ed.), Reframing organizational culture (pp. 11-14). Newbury Park, Calif.: Sage Publications.

Schein, E. H. (2010). Organizational culture and leadership. San Francisco: Jossey-Bass.

Schonfeld, R., \& Housewright, R. (2010). Faculty survey 2009: Key strategic insights for libraries, publishers, and societies: Ithaka S+R.

Shep, S. J. (2005). Historical investigation. In G. E. Gorman (Ed.), Qualitative research for the information professional : a practical handbook (pp. 160-181). London: Facet.

Sinclair, K. (1983). A history of the University of Auckland, 1883-1983. Auckland, N.Z.: Auckland University Press: Oxford University Press.

Slythe, R. M. (1973). Art college libraries - a personal view. In K. W. Neal (Ed.), British academic libraries (pp. 73-77). Wilmslow, Cheshire: K.W. Neal.

Smith, D. L., \& Baxter, E. G. (1965). College library administration in colleges of technology, art, commerce and further education. London: Oxford University Press.

Smith, G. (1975). The problems of centralised cataloguing for users of art material. ARLIS Newsletter, 23, 18-22.

Smith, I. (2011). Organisational quality and organisational change: Interconnecting paths to effectiveness. Library Management, 32(1/2), 111-128. doi: 10.1108/01435121111102629

Special Issue: Art librarians as artists. (1992). Art Libraries Journal, 17(1), 3-36.

Staikos, K., \& Cullen, T. (2004). The history of the library in Western civilization. New Castle: Oak Knoll Press.

Stracey, P. (1970). Croydon College of Art. ARLIS Newsletter, 5, 6-7.

Sutch, W. B. (1965). Automation - its implications for New Zealand. Wellington?: s.n. 
Tamaki Planning Committee. (1951, September 7). Memorandum for heads of department. [Questionnaire]. Fine Arts Library Archive, (Records up to 1962). Elam Archive, Fine Arts Library, The University of Auckland, Auckland, N.Z.

Taraba, S. (2003). Now what should we do with them?: artists' books in the curriculum. RBM: A Journal of Rare Books, Manuscripts, and Cultural Heritage, 4(2). Retrieved from http://rbm.acrl.org

Tenders for art school. (1960, September 31). New Zealand Herald.

Tenders: New School of Fine Arts, University of Auckland. (1960, September 14). New Zealand Herald.

The University of Auckland. (1973, September 9). Report of sub-committee to consider The School of Fine Arts. Fine Arts Library Archive, (Fine Arts Faculty 1970-73 Closed). Elam Archive, Fine Arts Library, The University of Auckland, Auckland, N.Z.

The University of Auckland. (1991, December). Report of the committee established to review the Elam School of Fine Arts. (08-008, Drawer K). Elam Archive, Fine Arts Library, The University of Auckland Auckland, N.Z.

The University of Auckland. (2001, August). Report of the committee established to review the Elam School of Fine Arts. (008/009, Drawer K). Elam Archive, Fine Arts Library, The University of Auckland Auckland, N.Z.

The University of Auckland. (2005, July). The University of Auckland: Report of the committee established to review the Department of Art History. The University of Auckland Senate Minutes. The University of Auckland Senate, Auckland.

The University of Auckland. (2006a). Teaching and Learning Policy: Information Literacy Retrieved March 20, 2011, from The University of Auckland website https://policies.auckland.ac.nz/policies/Policies/policy-display-register/informationliteracy-policy.pdf

The University of Auckland. (2006b). The University of Auckland Calendar 2006. Auckland, N.Z. : The University.

The University of Auckland. (2011). The University of Auckland 2011 Calendar. Auckland, N.Z.: The University. 
The University of Auckland Library. (1961a). University of Auckland libraries and archives report for the year 1961. Auckland, N.Z.: The University of Auckland Library.

The University of Auckland Library. (1961b, July). University of Auckland: Staff of libraries \& bindery History series, (E-10, Box 4, 7.3). General Library Special Collections, The University of Auckland, Auckland, N.Z.

The University of Auckland Library. (1962a). University of Auckland libraries and archives report for the year 1962. Auckland, N.Z.: The University of Auckland Library.

The University of Auckland Library. (1962b). University of Auckland: Library guide for new students. Manuscript. [Ephemera]. History series, (E-10, Box 5, 8.2). General Library Special Collections, The University of Auckland, Auckland, N.Z.

The University of Auckland Library. (1963). University of Auckland libraries and archives report for the year 1963. Auckland, N.Z.: The University of Auckland Library.

The University of Auckland Library. (1970). The University of Auckland report of the Librarian for the year 1969. Auckland, N.Z.: The University of Auckland Library.

The University of Auckland Library. (1971). The University of Auckland report of the Librarian for the year 1970. Auckland, N.Z.: The University of Auckland Library.

The University of Auckland Library. (1972). The University of Auckland report of the Librarian for the year 1971. Auckland, N.Z.: The University of Auckland Library.

The University of Auckland Library. (1974). The University of Auckland report of the Librarian for the year 1973. Auckland, N.Z.: The University of Auckland Library.

The University of Auckland Library. (1975). The University of Auckland report of the Librarian for the year 1974. Auckland, N.Z.: The University of Auckland Library.

The University of Auckland Library. (1981). The University of Auckland report of the Librarian for the year 1980. Auckland, N.Z.: The University of Auckland Library.

The University of Auckland Library. (1986). The University of Auckland report of the Librarian for the year 1985. Auckland, N.Z.: The University of Auckland Library. 
The University of Auckland Library. (1990). The University of Auckland report of the Librarian for the year 1989. Auckland, N.Z.: The University of Auckland Library.

The University of Auckland Library. (1991). The University of Auckland report of the Librarian for the year 1990. Auckland, N.Z.: The University of Auckland Library.

The University of Auckland Library. (1992). The University of Auckland report of the Librarian for the year 1991. Auckland, N.Z.: The University of Auckland Library.

The University of Auckland Library. (1993). The University of Auckland report of the Librarian for the year 1992. Auckland, N.Z.: The University of Auckland Library.

The University of Auckland Library. (1994). The University of Auckland report of the Librarian for the year 1993. Auckland, N.Z.: The University of Auckland Library.

The University of Auckland Library. (1995). Report of the University Librarian for the year 1994. Auckland, N.Z.: The University of Auckland Library.

The University of Auckland Library. (1996). Report of the University Librarian for the year 1995. Auckland, N.Z.: The University of Auckland Library.

The University of Auckland Library. (1997). Report of the University Librarian for the year 1996. Auckland, N.Z.: The University of Auckland Library.

The University of Auckland Library. (1999). The University of Auckland Library report of the University Librarian for the Year 1998. Auckland, N.Z.: The University of Auckland Library.

The University of Auckland Library. (2001). The University of Auckland Library report of the University Librarian for the year 2000. Auckland, N.Z.: The University of Auckland Library.

The University of Auckland Library. (2002). The University of Auckland Library report of the University Librarian for the year 2001. Auckland, N.Z.: The University of Auckland Library.

The University of Auckland Library. (2003). The University of Auckland Library report of the University Librarian for the year 2002. Auckland, N.Z.: The University of Auckland Library. 
The University of Auckland Library. (2004). Report of the University Librarian for the year 2003. Auckland, N.Z.: The University of Auckland Library.

The University of Auckland Library. (2005). The University of Auckland Library report of the University Librarian for the year 2004. Auckland, N.Z.: The University of Auckland Library.

The University of Auckland Library. (2006). The University of Auckland Library report of the University Librarian for the year 2005. Auckland, N.Z.: The University of Auckland Library.

The University of Auckland Library. (2007). The University of Auckland Library report of the University Librarian for the year 2007. Auckland, N.Z.: The University of Auckland Library.

The University of Auckland Library. (2009). The University of Auckland Library report of the University Librarian for the year 2008. Auckland, N.Z.: The University of Auckland Library.

The University of Auckland Library. (2010). Library annual report 2009. Auckland, N.Z.: The University of Auckland Library.

The University of Auckland Library. (2011). Library annual report 2010. Auckland, N.Z.: The University of Auckland Library.

The University of Otago Library. (1989). Library centre annual report - 1989. Dunedin, N.Z.: The University of Otago.

Thompson, J. (1982). The end of libraries. London: C. Bingley.

Thompson, J. (1983). The end of libraries. The Electronic Library, 1(4), 245 - 255. Retrieved from http://www.emeraldinsight.com

Toyne, D. (1977). A philosophy for Falmouth. Art Libraries Journal, 2(4), 24-30.

Trice, H. M., \& Beyer, J. M. (1984). Studying organizational cultures through rites and ceremonials. The Academy of Management Review, 9(4), 653-669. 
Trice, H. M., \& Beyer, J. M. (1987). How an organization's rites reveal its culture. Organizational Dynamics, 15(4), 5-24. doi: 10.1016/0090-2616(87)90041-6

Twiss, G. (1973). Attachments for agenda for faculty meeting to be held 2 p.m. Monday, 15th October, 1973, in Lecture Theatre: Quinquennial proposal - Exhibition area. Fine Arts Library Archive, (Fine Arts Faculty 1970-1973). Elam Archive, Fine Arts Library, The University of Auckland, Auckland, N.Z.

Twiss, G. (c.1983). Interview by Simon Franks. [Tape Recording]. (05-188). Elam Archive, Fine Arts Library, The University of Auckland, Auckland, N.Z.

Tyler, L. (2010). From the collection. University of Auckland News, 40(6), 7. Retrieved from http://www.auckland.ac.nz/uoa/tm-issue-archive

University of Auckland. (1974). Senate news. University of Auckland News, 4(7), 14-15.

University of Auckland Library. (1966, March). University of Auckland Library newsletter. [Newsletter]. (MSS \& A E10, Box 6, 9.7). General Library Special Collections, The University of Auckland, Auckland, N.Z.

University of Auckland Library. (2010). Library Annual Report. Auckland The University of Auckland Library.

University of Canterbury Library. (1986). University of Canterbury Library annual report 1985. Christchurch, N.Z.: University of Canterbury

University of Canterbury Library. (1987). University of Canterbury Library annual report 1986. Christchurch, N.Z.: University of Canterbury

Vaassen, S. (1962). Art school will soon have modern home in place of rubbish dump! The N.Z. Woman's Weekly, 37-40.

Valmestad, L. (2006). The Architecture / Fine Arts Library, Fort Garry Campus, University of Manitoba. In ARLIS/Canada (Ed.), Essays in the history of art librarianship in Canada (pp. 101-107). Ottawa: ARLIS/Canada. Retrieved from http://www.arliscanada.ca/hal/Arlis\%20online_28_06_06.pdf

Varley, G. (1977). The academic art library: some management problems Art Libraries Journal, 2(1), 11-17. 
Victoria University of Wellington Library. (1988). Annual report of the University Librarian for 1987. Wellington, N.Z.: Victoria University of Wellington.

Victoria University of Wellington Library. (1989). Annual report of the University Librarian for 1988. Wellington, N.Z.: Victoria University of Wellington.

von Meier, K. (1963a). ...From von Meier. Craccum: Auckland University College Students' Paper, 28(8), 12.

von Meier, K. (1963b). On Elam criticism. Craccum: Auckland University College Students' Paper, 28(8), 10.

von Meier, K. (1963c). von Meier states deficits in new Elam building. Craccum: Auckland University College Students' Paper, 28(5), 6-8.

von Meier, K. (c.1963). Preliminary proposals for a classification system related to the fine arts. Fine Arts Library Archive. Elam Archive, Fine Arts Library, The University of Auckland, Auckland, N.Z.

W.R. (1958). "It couldn't be worse". [Letter to the Editor]. Craccum: Auckland University College Students' Paper, 32(10).

Wainwright, E., \& Trask, M. (1993). Progress in partnership : review of the University of Auckland Library : Report to the Vice-Chancellor. Canberra, ACT: National Library of Australia.

Walker, J. (1970). A new general classification scheme: prospects and problems in relation to art libraries. ARLIS Newsletter, 6, 8-12.

Walker, J. (1971). LOMA : its creator Alexander. Davis interviewed by John Walker. ARLIS Newsletter, 7, 5-9.

Wall, C. (2010). Something to show for it: The place of mementoes in women's oral histories of work. Management \& Organizational History, 5(3-4), 378-394. doi: $10.1177 / 1744935910370194$

Walsh, F. (2007, November). The disappearing of Peggy Deamer. Metro, 84-93.

Walsh, R. R. (1969). Branch library planning in universities. Library Trends, 210-222. 
Wegner, J. (1980). Printed ephemera in libraires. ARLIS/ANZ News, 9, 25-28.

Weller, T. An information history decade: A review of the literature and concepts, 20002009. Library \& Information History, 26, 83-97. doi:

10.1179/175834909X12593374744122

Weller, T. (2007). Information history: its importance, relevance and future. Aslib Proceedings, 59(4), 437-448.

Weller, T. (2008). Information history : an introduction : exploring an emergent field: Oxford : Chandos Publishing, 2008.

Wertheimer, A. B. (2005). Quantifying the "goodness" of library history research: A bibliometric study of the Journal of Library History/Libraries \& Culture. Libraries \& Culture, 40(3), 267-284. doi:10.1353/lac.2005.0060

Who are your delegates? (1974). Laser(3), 4.

Willmot, L. (1970). Brighton Polytechnic Faculty of Art and Design Library. ARLIS Newsletter, 4, 3-5.

Wilson, C. (1984). New Zealand Bibliographic Network. Systems Newsletter(2), 1.

Wilson, S. (2006). A usable collection: The origins and growth of the University of Otago Library. In University of Otago. Dept. of English \& University of Otago. Dept. of History (Eds.), Culture of change : beginnings at the University of Otago (pp. 1-19). Dunedin: Departments of English and History, University of Otago.

Wilson, W. D. (1963). An architect's answer to Mr von Meier. Craccum: Auckland University College Students' Paper, 28(6), 7.

Wolfe, R. (1972a) Fine Arts Library Bulletin (Vol. 23): Fine Arts Library.

Wolfe, R. (1972b). On the art history front: A case against mental abuse. Elam seed, 2, 4-5.

Wolfe, R., \& Elam School of Fine Arts. (2010). Et in Elam ego. Elam School of Fine Arts. Auckland, N.Z. 
Yow, V. R. (2005). Recording oral history : a guide for the humanities and social sciences. Walnut Creek: AltaMira Press.

Zdravkovic, N. (2011). An investigation into the interactive teaching practices of librarians in information literacy instruction at the University of Auckland Library (Unpublished master's research paper). Retrieved from ResearchArchive@Victoria. 


\section{Appendix 1: List of Figures (full citations)}

The copyright holders have granted the researcher a non-exclusive and perpetual licence to include the materials listed in the print and digital copies of this thesis, for which, so far as they can determined, the individual is the copyright owner. This non-exclusive licence is granted on the understanding that should the identity of the original photographer(s) become known and they seek the removal of any or all of the photographs from this research, and provide evidence that they retained copyright in the photographs, that those photographs will be removed from this document.

Figure 1 The University of Auckland. (1963). Elam School of Fine Arts. [Photograph]. The University of Auckland Sesquicentennial Collection [AU125]. (MSS \& Archives 97/5). Copyright 1963 The University of Auckland Special Collections. Reprinted with permission.

Figure 2 Proposal for Library Layout. From Supervision of reading room and protection of Library property. F. A. Sandall, (1951, August 13). Fine Arts Library Archive, (Records up to 1962). Elam Archive, Fine Arts Library, The University of Auckland. Copyright 1951 The University of Auckland. Reprinted with permission.

Figure 3 [Library]. From Elam School of Fine Arts and Design. [Prospectus], by Elam School of Fine Arts (1958), p.10. Copyright 1958 The University of Auckland. Reprinted with permission.

Figure 4 [Library]. From Elam School of Fine Arts Prospectus, by Elam School of Fine Arts (1962), p.15. Copyright 1962 The University of Auckland. Reprinted with permission.

Figure 5 Elevation of the Elam School of Fine Arts, Fine Arts Library highlighted in yellow. Adapted from Massey, Beatson, Rix-Trott, Carter \& Co. (1960, April). School of Fine Arts Elevations. [Architectural Drawing]. Property Services. (Building number 431-2, Drawing Number 43120550). Property Services, The University of Auckland, Auckland. Copyright 1960 The University of Auckland. Reprinted with permission.

Figure 6 Administration wing and Library. Reprinted from Elam School of Fine Arts : building report (p.10), by C. Cochran, 1968, Auckland: University of Auckland. Copyright 1968 by Chris Cochran. Reprinted with permission.

Figure $7 \quad$ Plans of the Elam School of Fine Arts, Fine Arts Library highlighted in yellow. Adapted from Massey, Beatson, Rix-Trott, Carter \& Co. (1960, April). School of Fine Arts First Floor \& First Floor Mezzanine [Architectural Drawing]. Property Services. (Building number 431-2, Drawing Number 43120510). Property Services, The University of Auckland, Auckland. Copyright 1960 The University of Auckland. Reprinted with permission. 
Figure 8 Detail of the Fine Arts Library. Adapted from Massey, Beatson, Rix-Trott, Carter \& Co. (1960, April). School of Fine Arts First Floor \& First Floor Mezzanine [Architectural Drawing]. Property Services. (Building number 431-2, Drawing Number 43120510). Property Services, The University of Auckland, Auckland. Copyright 1960 The University of Auckland. Reprinted with permission.

Figure 9 Richards, V. (1965). Plan of Library Suggestions for permanent workroom 3rd August 1965. [Drawing]. Fine Arts Library Archive, (Library Plans 1963-1974). Elam Archive, Fine Arts Library, The University of Auckland, Auckland. Copyright 1965 The University of Auckland. Reprinted with permission.

Figure 10 Fine Arts Library. Reprinted from Elam: building report (p.26), by C. Cochran, 1968, Auckland: University of Auckland. Copyright 1968 by Chris Cochran. Reprinted with permission.

Figure 11 The University of Auckland. (1969). General Library and Divisional Libraries: Elam School of Fine Arts. [Photograph]. The University of Auckland Library History Series 1892-1997. (Manuscripts \& Archives E-10, Box 7, item 11.7.8, Slide 1). The University of Auckland Library Special Collections, Auckland. Copyright 1969 The University of Auckland Library Special Collections. Reprinted with permission.

Figure 12 The University of Auckland. (1969). General Library and Divisional Libraries: Elam School of Fine Arts. [Photograph]. The University of Auckland Library History Series 1892-1997. (Manuscripts \& Archives E-10, Box 7, item 11.7.8, Slide 6). The University of Auckland Library Special Collections, Auckland. Copyright 1969 The University of Auckland Library Special Collections. Reprinted with permission.

Figure 13 The University of Auckland. (1969). General Library and Divisional Libraries: Elam School of Fine Arts. [Photograph]. The University of Auckland Library History Series 1892-1997. (Manuscripts \& Archives E-10, Box 7, item 11.7.8, Slide 5). The University of Auckland Library Special Collections, Auckland. Copyright 1969 The University of Auckland Library Special Collections. Reprinted with permission.

Figure 14 Richards, V. (1965). AU:El School of Fine Arts Library Proposed Extensions to the Fine Arts Library: Mezzanine (Periodicals Only). [Drawing]. Fine Arts Library Archive, (Library Plans 1963-1974). Elam Archive, Fine Arts Library, The University of Auckland, Auckland. Copyright 1965 The University of Auckland. Reprinted with permission.

Figure 15 Richards, V. (1965). AU:El School of Fine Arts Library Proposed Extensions to the Fine Arts Library: Ground Floor. [Drawing]. Fine Arts Library Archive, (Library Plans 1963-1974). Elam Archive, Fine Arts Library, The University of Auckland, Auckland. Copyright 1965 The University of Auckland. Reprinted with permission.

Figure 16 Fine Arts Library. From Design at the Elam School of Fine Arts, by Elam School of Fine Arts (1975), p.20. Copyright 1975 The University of Auckland. Reprinted with permission. 
Figure 17 The University of Auckland. (1969). General Library and Divisional Libraries: Elam School of Fine Arts. [Photograph]. The University of Auckland Library History Series 1892-1997. (Manuscripts \& Archives E-10, Box 7, item 11.7.8, Slide 4). The University of Auckland Library Special Collections, Auckland. Copyright 1969 The University of Auckland Library Special Collections. Reprinted with permission.

Figure 18 Hill/Thomas/Jensen, \& Fletcher Challenge. (c.1968). [Photograph of Valerie Richards (Fine Arts Librarian) receiving cheque from Fletcher Industries for fence painting competition]. (90-026, Drawer G). Elam Archive, Fine Arts Library, The University of Auckland, Auckland. Copyright c.1968 Fletcher Challenge. Reprinted with permission.

Figure 19 “Fine Arts Library” by R. Wolfe, 1972, Fine Arts Library Bulletin, v.23, cover. Copyright 1972 by Richard Wolfe and The University of Auckland. Reprinted with permission.

Figure 20 Fine Arts Library, Nicol, G., Reid, T., \& Dadson, P. (1975). Open Drawers. [Photograph]. (99-009, Drawer I). Elam Archive, Fine Arts Library, The University of Auckland, Auckland. Copyright 1975 by Gray Nicol, Terry Reid and Phil Dadson. Reprinted with permission.

Figure 21 A plan for the additions to Fine Arts Library highlighted in yellow. Adapted from Beatson, Rix-Trott, Carter \& Co. (1975, August). Additions to School of Fine Arts - Main \& Mezzanine Floor Plan. [Architectural Drawing]. Property Services. (Building number 432, Drawing Number 43121120). Property Services, The University of Auckland, Auckland. Copyright 1975 The University of Auckland. Reprinted with permission.

Figure 22 Centre for Academic Development - Photography and Television Group (1976). [Exterior photograph of the Fine Arts Library extension]. Centre for Academic Development - Photography and Television Group. (760119 (2): Frame 5). Copyright 1976 The University of Auckland. Reprinted with permission.

Figure 23 Centre for Academic Development - Photography and Television Group (1976). [Fine Arts Library staff moving books and periodicals]. Centre for Academic Development - Photography and Television Group. (760119 (6): Frame 1). Copyright 1976 The University of Auckland. Reprinted with permission.

Figure 24 Wallace H. Floyd. (1976). [Photograph of Elam and Library staff]. Elam School of Fine Arts (Drawer H, slides 91-053 / Slide 1976-03) Elam Archive, Fine Arts Library, The University of Auckland. Copyright 1976 Wallace H. Floyd. Reprinted with permission.

Figure 25 Centre for Academic Development - Photography and Television Group (1976). [Interior photograph of the Fine Arts Library from front]. Centre for Academic Development - Photography and Television Group (760119 (1): Frame 3). Copyright 1976 The University of Auckland. Reprinted with permission. 
Figure 26 Centre for Academic Development - Photography and Television Group (1976). [Interior photograph of the Fine Arts Library from rear]. Centre for Academic Development - Photography and Television Group. (760119 (6) Frame 4). Copyright 1976 The University of Auckland. Reprinted with permission.

Figure 27 Fine Arts Library. (c.1977). [Photograph of entrance and front desk of the Fine Arts Library]. Fine Arts Library Archive. (Miscellaneous). Elam Archive, Fine Arts Library, The University of Auckland, Auckland. Copyright c.1977 The University of Auckland. Reprinted with permission.

Figure 28 Wallace H. Floyd. (1982). [Photograph of Professor Paul Beadle's farewell in the Elam Staff Common Room]. Elam School of Fine Arts (97-007) Elam Archive, Fine Arts Library, The University of Auckland. Copyright 1982 Wallace H. Floyd. Reprinted with permission.

Figure 29 Fine Arts Library. (1990, August 10). [Photograph of Valerie Richards on her retirement]. (90-025, Drawer G). Elam Archive, Fine Arts Library, The University of Auckland, Auckland. Copyright 1990 the Elam Archive, The University of Auckland. Reprinted with permission.

Figure 30 Fine Arts Library. (1990, August 10). [Photograph of Gail Keefe serving a patron]. (90-025, Drawer G). Elam Archive, Fine Arts Library, The University of Auckland, Auckland. Copyright 1990 the Elam Archive, The University of Auckland. Reprinted with permission.

Figure 31 Stone, L. (c.1990-1994). [Photograph of card catalogue and front desk arrangement]. A gift for the Fine Arts Library. (Drawer K, 08-095). Elam Archive, Fine Arts Library, The University of Auckland, Auckland. Copyright c.1990-1994 Lynley Stone. Reprinted with permission.

Figure 32 Stone, L. (c.1990-1994). [Photograph of Library assistant desks]. A gift for the Fine Arts Library. (Drawer K, 08-095). Elam Archive, Fine Arts Library, The University of Auckland, Auckland. Copyright c.1990-1994 Lynley Stone. Reprinted with permission.

Figure 33 Stone, L. (c.1990-1994). [Photograph of typewriter in Fine Arts Library backroom]. A gift for the Fine Arts Library. (Drawer K, 08-095). Elam Archive, Fine Arts Library, The University of Auckland, Auckland. Copyright c.1990-1994 Lynley Stone. Reprinted with permission.

Figure 34 Stone, L. (c.1990-1994). [Photograph of Fine Arts Library staff]. A gift for the Fine Arts Library. (Drawer K, 08-095). Elam Archive, Fine Arts Library, The University of Auckland, Auckland. Copyright c.1990-1994 Lynley Stone. Reprinted with permission.

Figure 35 Gilbert, P. (c.2001). [Photograph of Fine Arts Library staff]. Fine Arts Library Archive, Elam Archive, Fine Arts Library, The University of Auckland, Auckland. Copyright c.2001 Paul Gilbert. Reprinted with permission.

Figure 36 Fine Arts Library, \& Keefe, G. (c.2001). Proposal No.1. [Drawing]. (08-015, Drawer K). Elam Archive, Fine Arts Library, The University of Auckland, Auckland. Copyright c.2001 the Elam Archive, The University of Auckland. 
Reprinted with permission.

Figure 37 Passau, V. (2011, May 23). [Photograph of the front desk of the Fine Arts Library].

Figure 38 Passau, V. (2011, May 26). [Photograph of Fine Arts Library Staff].

Figure 39 Passau, V. (2011, March 23). [Photograph of the new books and serial reading area].

Figure 40 Stone, L. (c.1990-1994). [Photograph of the view down the Fine Arts Library]. A gift for the Fine Arts Library. (Drawer K, 08-095). Elam Archive, Fine Arts Library, The University of Auckland, Auckland. Copyright c.1990-1994 Lynley Stone. Reprinted with permission.

Figure 41 Passau, V. (2011, March 23). [Photograph of the view down the Fine Arts Library]. 


\section{Appendix 2: Participant Information Sheet}

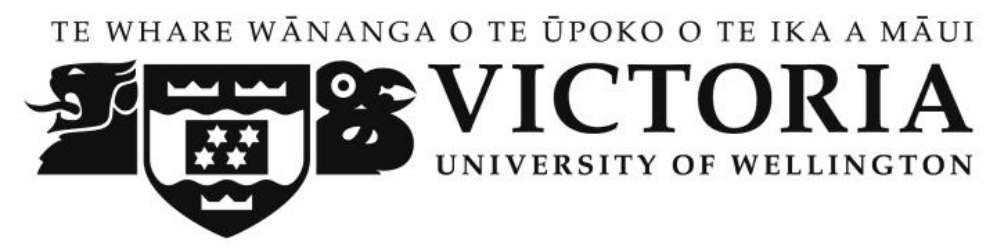

\section{Participant Information Sheet for a Study of the Fine Arts Library, The University of Auckland.}

Researcher: Victoria Passau: School of Information Management, Victoria University of Wellington.

The purpose of this study is to examine how the relationship between the Elam School of Fine Arts and its various institutional affiliations influenced the development, maintenance, and future of a specialised art library.

This study will include an exploration of the relationships the library has had with The Elam School of Fine Arts, Art History Department and The University Library as a whole. Information will be gathered from primary sources including oral history interviews and archival materials. This study is to be completed by the $7^{\text {th }}$ of June 2011 .

This study has been granted approval by the School of Information Management Ethics Committee at Victoria, University of Wellington. Participation in this project will involve an interview with the Researcher, Victoria Passau, and a list of questions indicative of what will be asked, will be made available before the interview date. It is envisaged that the oral history interview will take approximately $60-90$ minutes. The interview will be recorded with a digital recorder, with your approval, and notes may also be taken during the interview. Pertinent sections of the interview recordings will be transcribed by the Researcher - they will be securely stored, along with any associated notes, and made accessible only to the Researcher and Project Supervisor (Dr Sydney Shep). In some cases a follow-up interview may be necessary. The interviews will be conducted at a place that is private, convenient and agreed upon by the Researcher and you.

The interview(s) will explore your experiences of working at the Fine Arts Library, of working conditions and the relationship the Fine Arts Library has with a number of institutional partners. In addition you may be asked to discuss influences or changes that occurred in regards to librarianship during their working life.

Responses collected will form the basis of this research project and will be put into a written report. Please note that this study does not guarantee anonymity (as you will be named in the study), or confidentiality (as the information given during the interview will be attributed to you).

As a research participant you can refuse to answer any interview questions and / or withdraw from the study before the data analysis phase of the study begins. If you chose to withdraw from this study, all information provided by you up until that point will be destroyed and excluded from this study. 


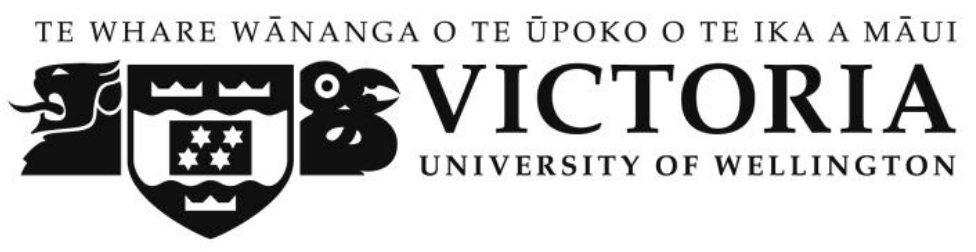

The final research report will be submitted for marking to the School of Information Management and deposited in the University Library. It is intended that one or more articles will be submitted for publication in scholarly journals. In addition, an exhibition, which will be curated by the Researcher, pertaining to the history of the Fine Arts Library, is to be displayed at the Elam School of Fine Arts in late June to early July 2011. Please be aware that recordings or portions of the transcript maybe used as part of an exhibition celebrating the history of the Fine Arts Library.

As stipulated in the conditions of receiving the Paul Szentirmay Special Librarianship Scholarship (2010) results of this research will be disseminated by:

- Submitting a research paper to a LIANZA publication

- Delivering a paper at a LIANZA Conference / Workshop

Because of the value of historical information to present and future generations, the recordings will be deposited in the Elam Archive at the end of the project. Any instances where personal information is divulged would be edited from your recording before being stored as part of the Elam Archive.

If you are not comfortable with your interview being retained in this manner you can opt, in the Consent Form, to have the recordings and associated notes destroyed after a period of two years the recordings will be securely stored with restricted access during that time. During that two year period, the Researcher may refer to this information for publication in academic or professional journals and/or academic or professional conferences.

If you wish to participate in this study, please read through the Consent Form, tick the statements you agree to, sign and date. It would be greatly appreciated if you contact the Researcher at your earliest convenience to organise a time to conduct an interview. Many thanks for your time and I look forward to hearing from you.

If you have any questions or would like to receive further information about the project, please contact me on (09) 3737599 (ext 85733), passauvict@myvuw.ac.nz or my supervisor, Dr Sydney Shep at The Printer, Wai-te-ata Press at Victoria University, P O Box 600, Wellington, phone (04) 4635784.

Victoria Passau 


\section{Appendix 3: Consent to Participate in Research}

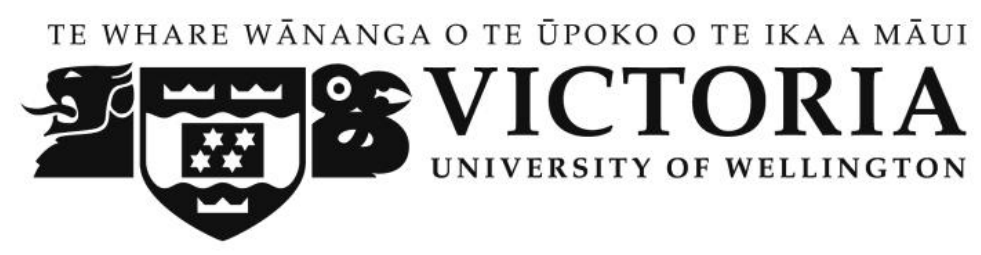

CONSENT TO PARTICIPATE IN RESEARCH

Title: A portrait of the Library: A fine history

How has the relationship between the Elam School of Fine Arts and its various institutional affiliations influenced the development, maintenance, and future of a specialised art library?

Researcher: Victoria Passau

Project Supervisor: Dr Sydney Shep

I have been given and have understood an explanation of this research project.

I have had an opportunity to ask questions and have them answered to my satisfaction.

I understand that I may withdraw myself (or any information I have provided) from this project (before data collection and analysis is complete) without having to give reasons or without penalty of any sort. If you I do withdraw all information provided by me until that point will be destroyed and excluded from this study.

I consent to information or opinions which I have given being attributed to me in this and any other reports on this research.

I consent to the interview being recorded and;

I consent to the recordings and notes to be retained as part of the Fine Arts Library Archives in the Elam Archive in a secure collection with restricted access. In this instance, any aspects of the interview that divulges personal information will be edited from the recordings. 


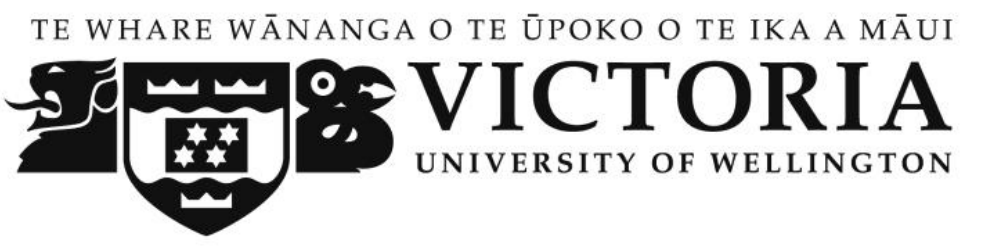

OR

I consent to the recordings and notes to be retained as part of the Fine Arts Library Archives in the Elam Archive in a secure collection with restricted access for a period of two years. During this time the recordings and notes will be accessible only to the Researcher and Supervisor. After this time I consent to the recording and notes being destroyed.

I understand that the interview recording will be deposited in the Elam Archive under the conditions selected above.

I understand that I will have an opportunity to check the transcripts of the interview before publication.

I understand that recordings or portions of the transcript maybe used as part of an exhibition celebrating the history of the Fine Arts Library, to be displayed at the Elam School of Fine Arts in late June to early July 2011.

I understand that the final results of the research will be presented at a LIANZA Conference or Workshop.

I consent to a research paper being submitted and printed in a LIANZA publication.

I agree to take part in this research.

Participants signature:

Name of participant:

Date: 


\section{Appendix 4: Participant Profiles}

\section{Jane Dodd (Full-time and Part-time Library Assistant and Archivist 1987- 2007)}

Jane Dodd studied at the University of Otago receiving her Bachelor of Arts in 1984. Jane joined the AUEL staff in 1987 and was a Library Assistant until 1989. Dodd returned to work at the Fine Arts Library in the early 1990s and worked in range of part-time roles throughout the following decade. Dodd received a Diploma in 3D design majoring in jewellery from Unitec in 1994 and has gone on to become an accomplished jeweler. From the early 2000s until 2008 Dodd worked one day a week in the Elam Archive.

\section{Valerie Richards (Fine Arts Librarian from 1965-1990)}

Prior to gaining the position of Librarian-in-charge at the AUEL in 1965 Valerie Richards (nee Lockwood) had worked for three years at the Architecture Library at The University of Auckland under Lillian Cummings. She also had previous library experience from a period working at the Ardmore Teachers' Training College (V. Richards, personal communication, April 8, 2011). Richards was highly involved the establishment in the Art Libraries Society Australia New Zealand (ARLIS/ANZ) and attended a number of international art conferences throughout her career at the AUEL. Richards remained in the position of Fine Arts Librarian until her retirement in 1990.

\section{Lynley Stone (Deputy Fine Arts Librarian 1990-1994)}

Lynley Stone completed her Bachelor of Arts, majoring in English and Art History from The University of Auckland in 1985. Stone went on to work at The University of Auckland's General Library between 1987 and 1990. In 1990 she completed her Graduate Diploma in Librarianship from Victoria University and was appointed Assistant Librarian at the AUEL at the end of that same year. Lynley was instrumental in the automation of the AUEL catalogue and was responsible for this project throughout the four years she remained in the position.

In 1994 Stone left the role and became the Senior Librarian at the newly created Tamaki Library. Between 1998 and 2000 Stone was the Customer Service Manager and the University of Waikato Library. In 2001 she acquired two tutoring and facilitating positions as the Auckland Tutor/Senior Tutor, School of Information Management, Victoria University of Wellington (2001-2010) and as the Adjunct Faculty, Information and Library Studies, The Open Polytechnic of New Zealand (2001-present). In that same year Stone created the Information Workshop an information consultancy which is her current focus.

\section{Jane Wild}

Since receiving her in Diploma of Librarianship from VUW in 1980 Jane Wild has worked in diverse Special Libraries, including the New Zealand Wool Board Library and the Alexander Turnbull Library. In 1999, after a long career at Auckland City Libraries Wild became the Manager of the Symonds Street Group which included the AUEL. Wild is the AUEL's current Manager as well as the Manager of the National Institute of Creative Arts and Industries Libraries and Special Collections. 


\section{Appendix 5: Oral History Schedule}

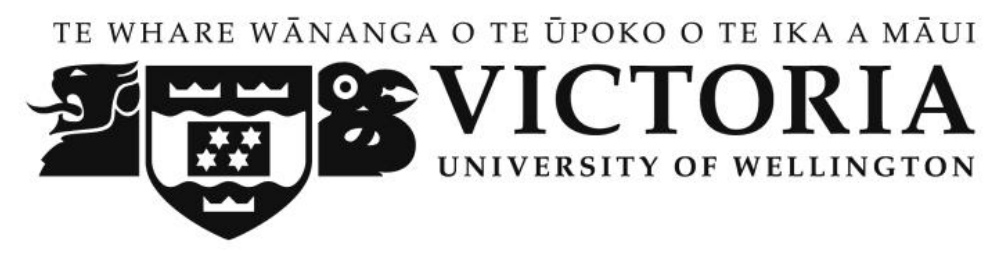

\section{Oral history schedule for a study of the Fine Arts Library, The University of Auckland.}

\section{Educational background}

Could we start out by discussing your educational background?

At what point did you decide you wanted to make your career in librarianship? Why?

Why did you apply for the position at the Fine Arts Library? Did you also apply for positions elsewhere?

What sort of working conditions did you find when you arrived? (space and equipment, staffing)

\section{Staffing}

Tell me about the staffing at the Fine Arts Library? (structure, meetings, part-time staff, areas of responsibility, roles)

How would you describe the culture of the Fine Arts Library?

What changes occurred over time? How did they meet the needs of the library?

\section{Collection development and specific initiatives}

Describe the collection in terms of subject coverage and cataloguing description when you first arrived at the Fine Arts Library?

What areas were best represented? Why do you think that was?

What limitations did you identify and how did you reconcile these shortcomings?

Can you identify and explore any significant shifts in focus in terms of the Collection Development Policy?

Can you recall any particular library initiatives or projects that you championed? For example INZART (Index to New Zealand Art), Elam Archive, AHID (Art History Image Database) 


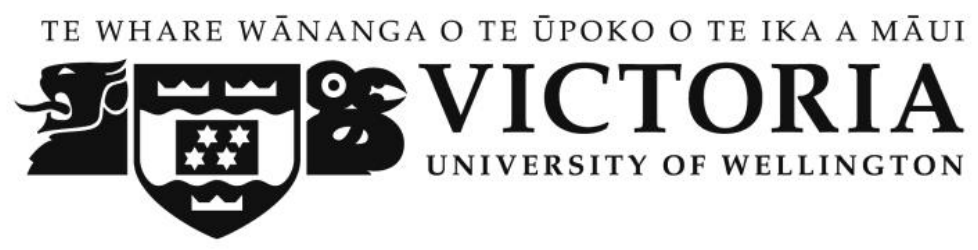

When you introduced these proposals to the Library / School committees did you encounter any objections? What level of support was provided to you by the Departments and the General Library?

\section{Organisational}

Tell me how the Fine Arts Library fitted into the wider library organisation?

Describe the relationship you had with the General Library and senior library management? (Formal / informal lines of communication)

Were there ever any suggestions for some kind of fundamental restructuring or physical moving of the library?

\section{Technology}

Could you describe what major changes to technology were implemented during your time at the Fine Arts Library?

In what ways did this effect your position and the library service?

\section{Librarianship}

How did you usually learn about important new developments in librarianship? (attending conferences, organisational memos, internal training, journal articles)

\section{Finance}

Could you outline the funding for the Fine Arts Library? Please describe any financial problems and gains encountered?

\section{Physical}

As the collection grew what issues did you experience in terms of physical space?

What barriers did the library face to gain more space or at least a more effective use of space?

What approach did you take to increase functionality and streamline workflow?

Discuss how the limitations of space were acknowledged and resolved by senior library management? 
TE WHARE WĀNANGA O TE ŪPOKO O TE IKA A MĀUI

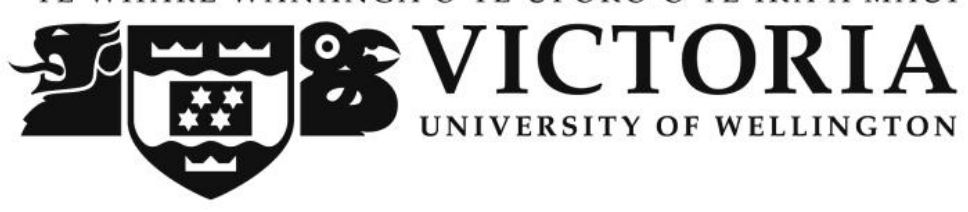

\section{Elam School of Fine Arts and Art History Department}

How much autonomy did the library have in regards to acquisitions?

Was either the School or Art History Department involved in deciding what books or items to purchase? How did this situation effect the collection?

Describe the position / significance of the library within those two organisations?

How did you perceive the academic effectiveness of these departments? How much was this reliant on the quality of the library?

What changes did you experience in terms of teaching style at Elam? How did this change the needs of the library users both in regards to students and staff?

Could you also explore the same question in terms of the Art History Department?

\section{Students}

Tell me about the relationship the library had with the students?

What types of resources were available for providing library instruction?

Could you explore the significance and effectiveness of library tutorials and tours?

\section{Archival sources}

What records exist for understanding the history of library?

\section{Conclusion}

Are there any questions I've not asked you which you would like to raise?

Are there any topics you would like to return to and say more about? 


\section{Appendix 6: List of Questions Sent to the Department of Art History}

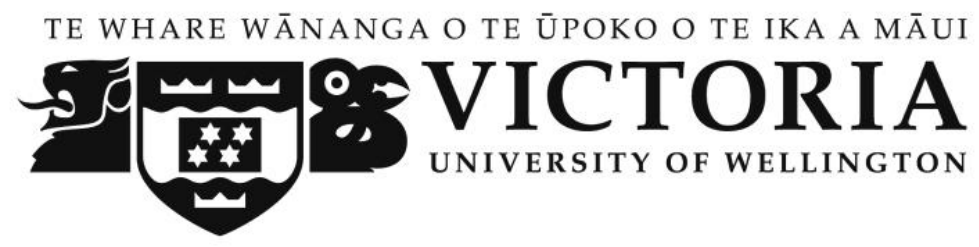

Describe the position / significance of the Fine Arts Library within the Department of Art History during your time as HOD?

Describe the current position / significance of the Fine Arts Library within the Department of Art History?

How did you perceive the academic effectiveness of the Department of Art History during your time as HOD? How much was this reliant on the quality of the Fine Arts Library?

How do you perceive the current academic effectiveness of the Department of Art History? How much is this reliant on the quality of the Fine Arts Library?

How would you describe the relationship the Fine Arts Library has with the Department of Art History? How has this changed over time?

What role do you think the Fine Arts Library has in the future of the Art History Department?

Are there anyways that the Fine Arts Library service could be improved? Why and how. 